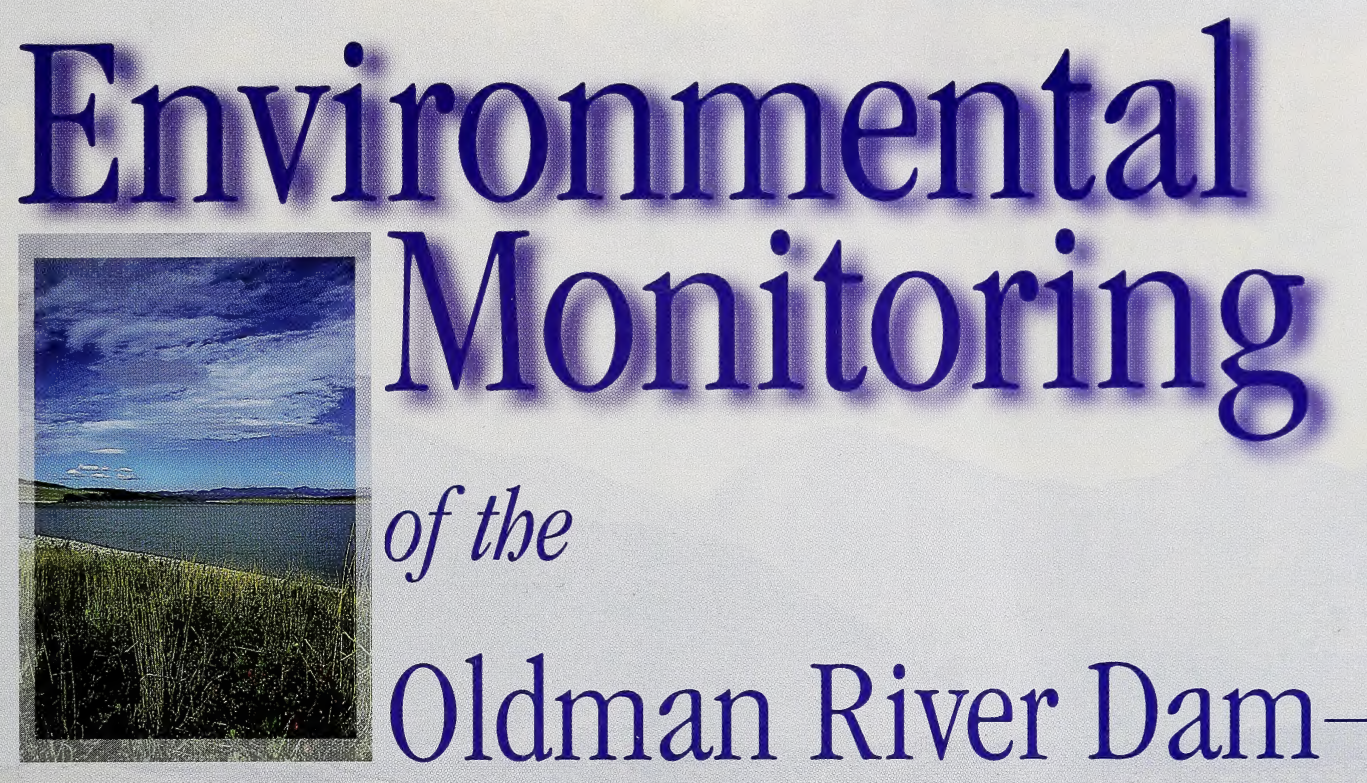





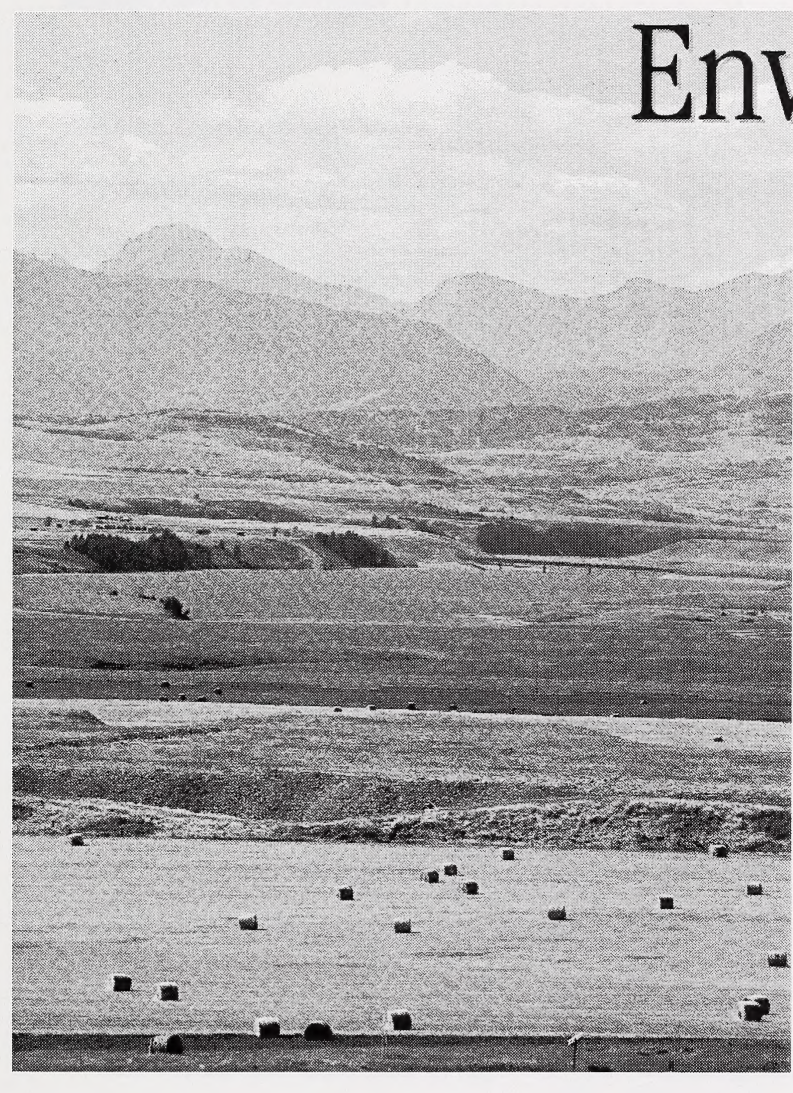

\section{Environmental Monitoring} of the Oldman

\section{River Dam:}

\section{Eight Years of Progress}

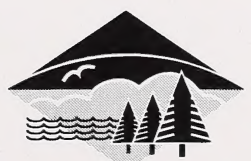


For additional copies of this report please contact:

\author{
Russ Lewis \\ Natural Resources Service \\ Alberta Environmental Protection \\ 3rd Floor, Deerfoot Square \\ 2938 - 11 Street N.E. \\ Calgary, Alberta \\ T3E 7L7 \\ Phone: (403) 297-5952 \\ Fax: (403) 297-6069 \\ e-mail: Russ.Lewis@gov.ab.ca \\ Information Centre \\ Alberta Environmental Protection \\ Main Floor, Great West Life Building \\ 9920 - 108 Street \\ Edmonton, Alberta \\ T5K $2 \mathrm{M} 4$ \\ Phone: (780) 422-2079 \\ FAX: $\quad$ (780) 427-4407
}

ISBN - 0-7785-0590-1

Pub No T/447 


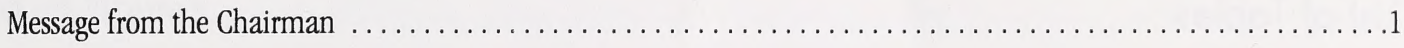

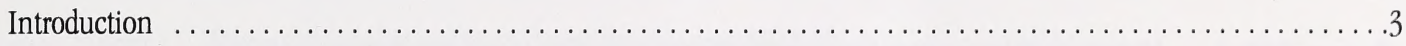

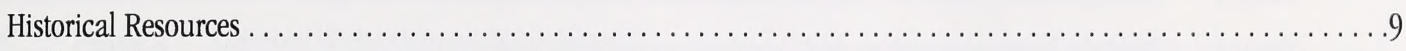

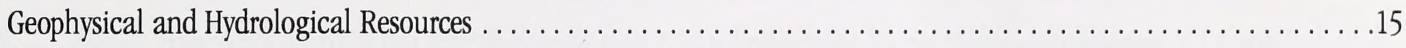

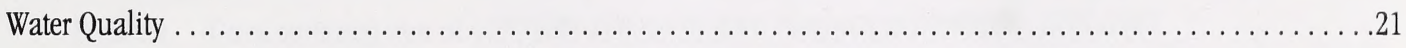

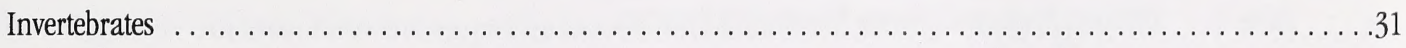

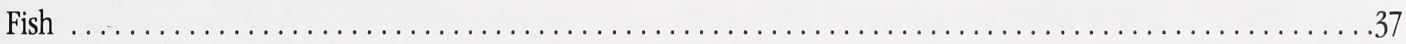

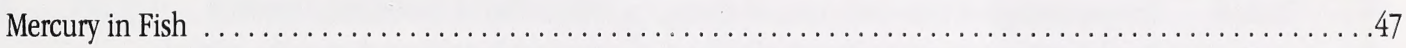

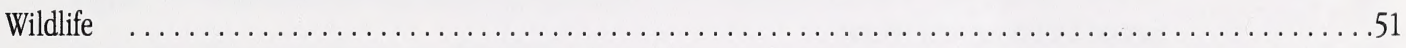

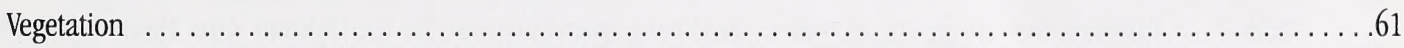

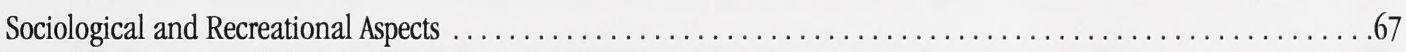

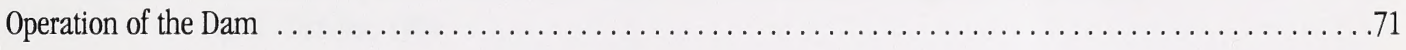

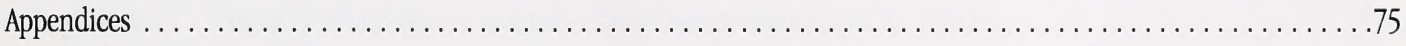

A. Oldman River Dam Environmental Monitoring Committee: Objectives, Terms of Reference . . . . . . . . . 75 and Scope of Monitoring Program

B. Members of the Oldman River Dam Environmental Monitoring Committee $\ldots \ldots \ldots \ldots \ldots \ldots \ldots \ldots$

C. Evaluation Criteria for Establishing Monitoring Priorities $\ldots \ldots \ldots \ldots \ldots \ldots \ldots \ldots \ldots \ldots \ldots \ldots \ldots \ldots \ldots \ldots \ldots \ldots \ldots$

D. Terms and Conditions of Approval under the Navigable Waters Protection Act $\ldots \ldots \ldots \ldots \ldots \ldots \ldots$

E. Conditions of Authorization - Canada Department of Fisheries and Oceans $\ldots \ldots \ldots \ldots \ldots \ldots \ldots \ldots$ 
List of Tables

Table 1 History of Oldman River Dam environmental mitigation and monitoring ...........................................5

Table 2 Oldman River temperature and dissolved oxygen monitoring ….........................................................25

Table 3 Average concentrations of chlorophyll $a$ and total phosphorus in the Oldman Reservoir .....................27 1991-1994, May-October euphotic zone composite samples

Table 4 Oldman River Invertebrate Monitoring Program ...............................................................................32

Table 5 Prairie falcon nest occupancy 1968 - 1996.....................................................................................57

Table 6 The percentage of time daily rates of change in stream flow of the Oldman River at ..........................64 Brocket met requirements for establishment of cottonwood seedlings during the critical period following seed release

Table 7 Instream flow requirements used in developing operating plans for the Oldman River Dam . .74 


\section{List of Figures}

Figure 1 Environmental Monitoring Committee Budget $1992-98 \ldots \ldots \ldots \ldots \ldots \ldots \ldots \ldots \ldots \ldots \ldots \ldots$

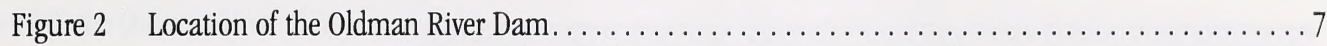

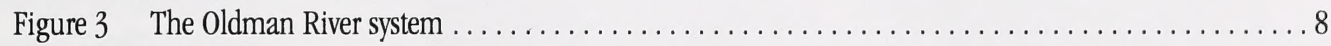

Figure 4 Cross sectional view of the Castle River channel just upstream of the Reservoir . . . . . . . . . . 17

Figure 5 Oldman River thalweg profiles between Cottonwood and Summerview bridges, . . . . . . . . . 18 1987, 1995 and 1996.

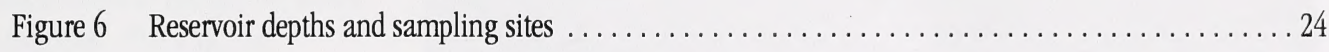

Figure 7 Oldman River thermograph and datasonde installation sites $1991-1998 \ldots \ldots \ldots \ldots \ldots \ldots \ldots 26$

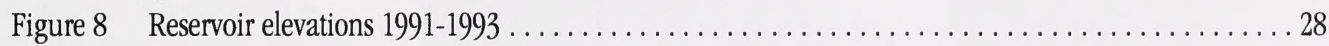

Figure 9 Oldman River benthic invertebrate monitoring sites $1992-1997 \ldots \ldots \ldots \ldots \ldots \ldots \ldots \ldots \ldots$

Figure 10 Estimation of habitat flow requirements: brown trout in the Oldman River Reservoir . . . . . . . 38 April - October, 1994

Figure 11 Example of bull trout movement (from Golder Associates Ltd. 1996c) . . . . . . . . . . . . . 41 .

Figure 12 Mean monthly catch rates for rainbow trout in the Oldman River Reservoir, . . . . . . . . . 43 April - October, 1994 (from Ripley 1995a)

Figure 13 Adjusted mean total mercury concentrations in muscle of bull trout from the Oldman River Reservoir, 1991 - 1997 (from Wu et al. 1998)

Figure 14 Habitat types before and after construction of the Oldman River Reservoir ............... 52 (adapted from Horbeck 1998)

Figure 15 Artificial wetlands surveyed for waterfowl $(1997) \ldots \ldots \ldots \ldots \ldots \ldots \ldots \ldots \ldots \ldots \ldots \ldots \ldots \ldots \ldots \ldots \ldots \ldots$

Figure 16 Operating guidelines for Oldman River Reservoir levels $\ldots \ldots \ldots \ldots \ldots \ldots \ldots \ldots \ldots \ldots \ldots$ 

The 0ldman River Dam has become an integral part of water management in Southern Alberta, reliably supplying water for municipal, domestic, irrigation, industrial and other needs. It provides operational flexibility to meet the requirements of the riparian and aquatic environments.

Since 1991 the Oldman River Dam Environmental Monitoring Committee (EMC) has been monitoring the impacts of the dam, assembling data for the review of impact predictions and examining the effectiveness of mitigation works and strategies. The EMC has addressed its task with great enthusiasm and has produced a significant body of relevant, first-rate scientific knowledge. This report provides a first look at the results of the overall monitoring program.

The focus of the monitoring is changing as some programs near

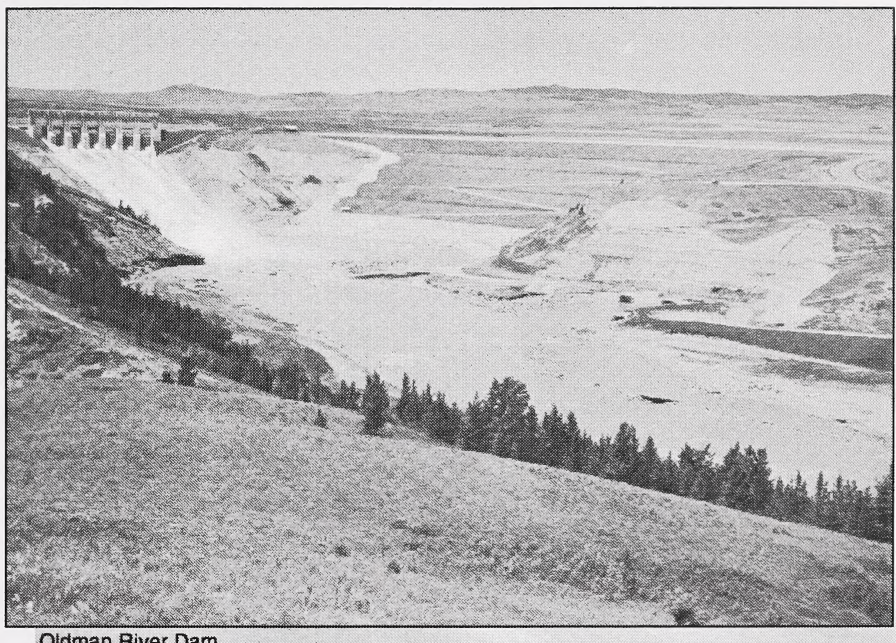

Oldman River Dam completion. The EMC is presently working towards the production of a comprehensive report which will provide an overall assessment of all the monitoring results. The work program, while funded and led by Alberta Environmental Protection, has been a joint effort. Partners include the provincial departments of Community Development and Public Works, Supply and Services, as well as the Alberta Research Council and the federal Department of Fisheries and Oceans. The EMC has enjoyed the input of the Oldman River Dam Environmental Advisory Committee (EAC), a public stakeholder group which has provided much valuable advice. The EAC has broadened our perspective and helped us link science and public concern as we have set the monitoring priorities.

I hope you will find this summary report both interesting and informative. I would like to thank the members of the Committee who have made it such a pleasurable and interesting group to chair.

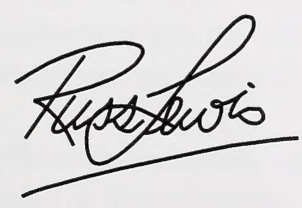

Russ Lewis

Chairman

Oldman River Dam Environmental Monitoring Committee 
Environmental Monitoring of the Oldman River Dam: Eight Years of Progress

2 


\section{Background to This Report}

This report summarizes the results to date of the Oldman River Dam Environmental Monitoring Program. This program is under the direction of the Oldman River Dam Environmental Monitoring Committee (EMC), an interdisciplinary committee established by Alberta Environment in 1991 to:

$\llcorner$ evaluate the performance of the mitigation projects

$L$ report on the environmental effects of the dam and of downstream conditions

$\llcorner$ compare recorded environmental effects to impact predictions made prior to completion of the dam.

Programs have been developed for monitoring water quality, fish, historical resources, wildlife, vegetation and geophysical and hydrological aspects and sociological impacts (Table 1). Some of this work is still underway.

Monitoring represents the final stage in the process of addressing the environmental consequences of the Oldman River Dam. The process began with the commitment made in 1984 by the Government of Alberta to avoid, reduce, or compensate for the negative environmental impacts of the dam. To achieve this objective, four basic questions were addressed:

\section{Where are we now?}

As a first step, all available information about the resources that might be affected by the dam was gathered and reviewed. Areas in which there was insufficient information for predicting impacts, planning mitigation work, or making pre- and post-impoundment comparisons were then identified and inventories and studies were commissioned to fill these information gaps.

\section{Where do we want to go from here?}

Based on this information, predictions and assumptions were made about the impacts of the dam. This enabled strategies to be developed to protect, replace, or restore the resources likely to be affected. Priorities for protection and replacement were based on recommendations put forward by the Oldman River Dam Local Advisory Committee. Potential benefits such as increased recreational opportunities were also explored.

\section{How do we get there?}

The next step was to develop specific action plans by which these mitigation strategies could be carried out. The action plans covered a wide scope, from operation of the dam to the construction of raptor nesting sites. A total project cost of $\$ 13.3$ million made this the largest mitigation program ever undertaken in Alberta.

\section{Are we there yet?}

The last step in the process is monitoring. Only by monitoring can we know whether the action plans achieve their intended objectives and whether the initial predictions and assumptions upon which they were based were correct. Monitoring will also reveal impacts that were not predicted, should they occur. The findings of the monitoring program will be relevant to mitigation of impacts from many kinds of development in Alberta and elsewhere. Federal review of the Oldman River Dam project led to the issuance of permits under the Navigable Waters Protection Act and the Fisheries Act and established specific requirements for environmental monitoring.

Members of the Environmental Monitoring Committee are drawn from Alberta Environmental Protection, Public Works, Supply and Services, and other departments involved in planning, environmental monitoring and impact assessment, mitigation works design and implementation, and operation of the Oldman River Dam. Fisheries and Oceans Canada (Freshwater Institute) is also represented. The Terms of Reference for the Committee are contained in Appendix A and members of the Committee are listed in Appendix B.

EMC members share knowledge of their field of expertise with each other and allocate budget and resources for 
projects on a group consensus basis. Projects have been carried out by consultants, government departments, universities - from individual researchers to entire classes - and the Alberta Research Council. The EMC has stressed the need for strong and relevant science in the work it has commissioned. Projects have been designed to expand the scientific knowledge in a field whenever this could be achieved efficiently while meeting monitoring requirements.

The EMC also serves as a technical resource group to the Oldman River Dam Environmental

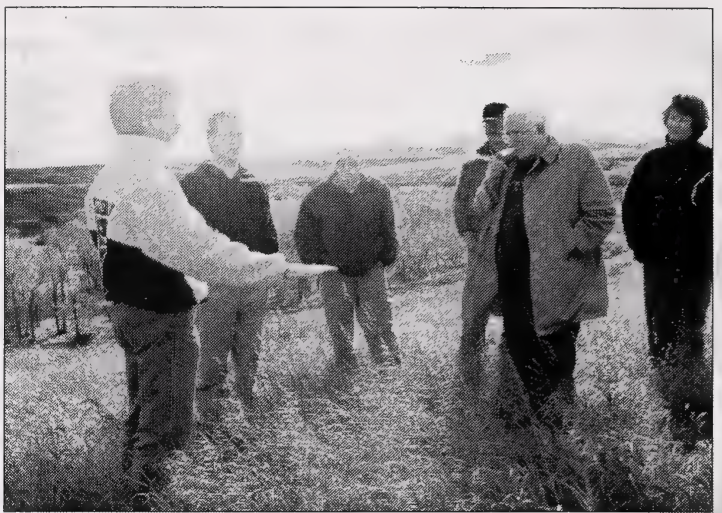

John Mahoney (Project Biologist) with members of the Environmental Advisory Committee Advisory Committee (EAC), a public advisory group reporting to the Minister of Environmental Protection. The EAC replaced the Oldman River Dam Local Advisory Committee in 1993. At this time, the Local Advisory Committee recommended a number of areas where future monitoring was needed. These recommendations were incorporated into the current monitoring program. In addition, the EMC updates the EAC each year on the findings of its monitoring work and presents its monitoring plans for comment and recommendations. This has proven to be a two-way communication that has provided support and a knowledgeable audience for the work of the EMC.

Initially the EMC concentrated on ensuring that adequate baseline information existed and that rigorous monitoring programs were developed. As budgets declined (Figure 1), priorizing the work to be commissioned assumed increasing importance. Criteria for selecting proposed projects are described in Appendix $\mathrm{C}$ and include timeliness, continuity of data, significance to monitoring program objectives, linkage to other components, and irreversibility of impacts addressed.

\section{Figure 1}

Environmental Monitoring Committee Budget, 1992 - 1998

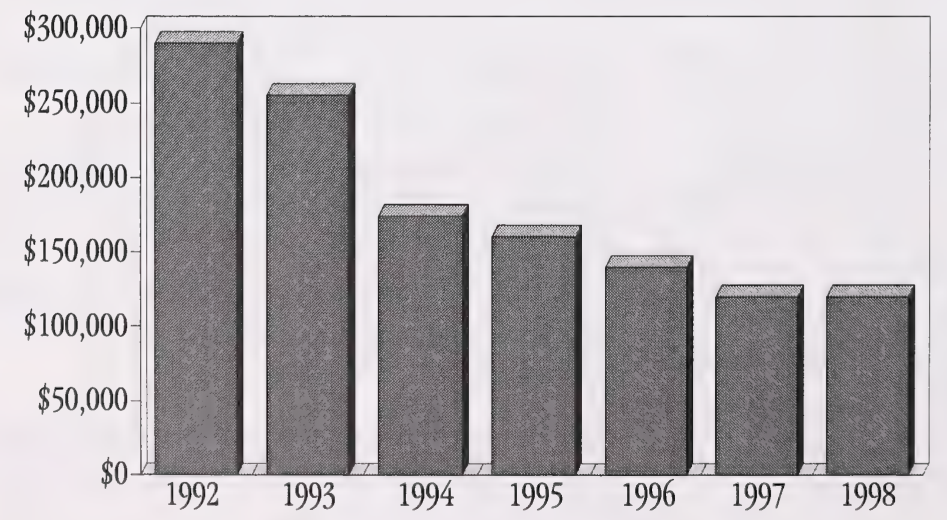

Presently the Committee is reexamining what has been accomplished and identifying information gaps prior to designing a long-term monitoring plan that can be integrated into the work plans of the departments involved. A tenyear summary report is planned for 2005 . 
Table 1

History of Oldman River Dam environmental mitigation and monitoring

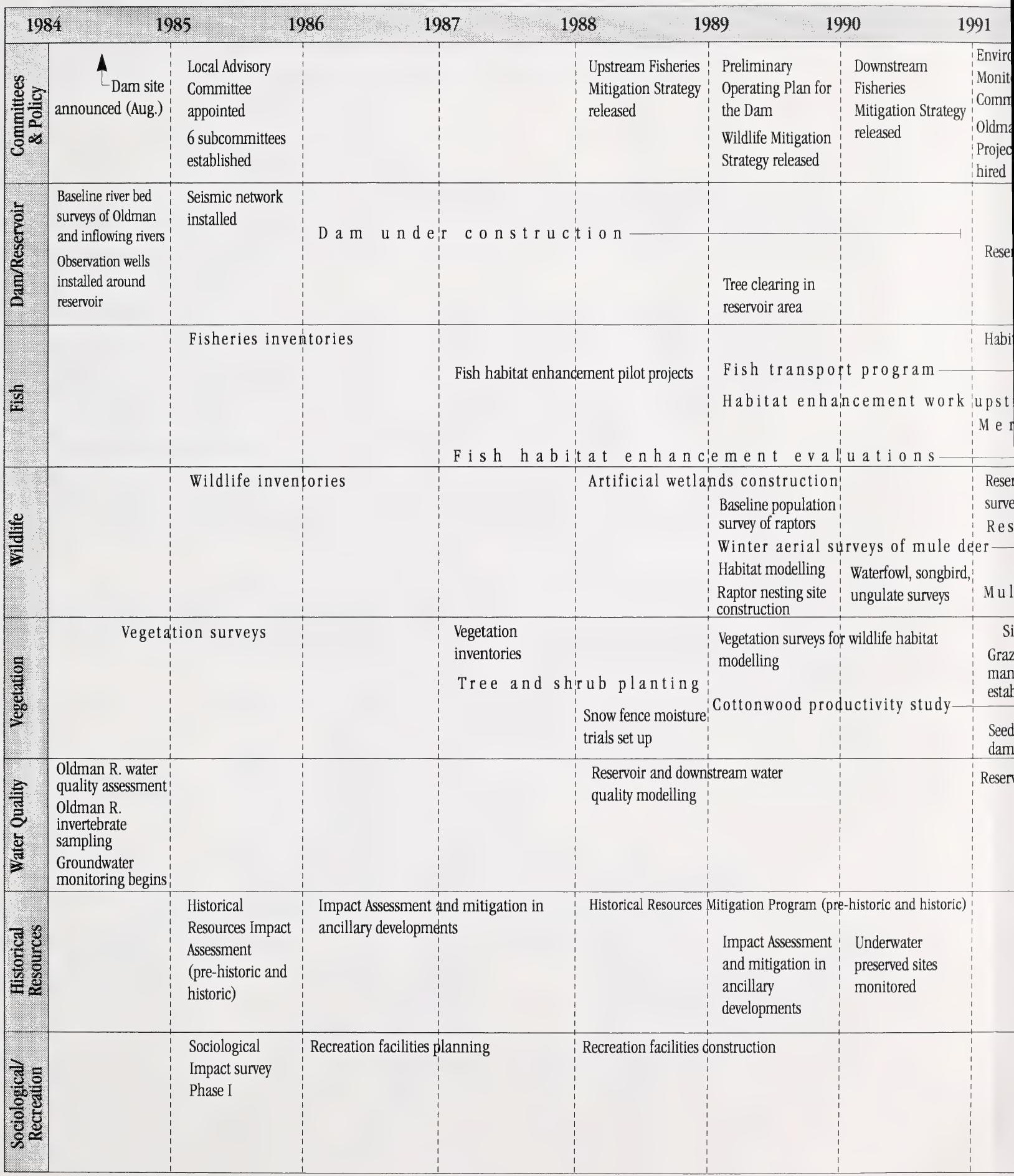




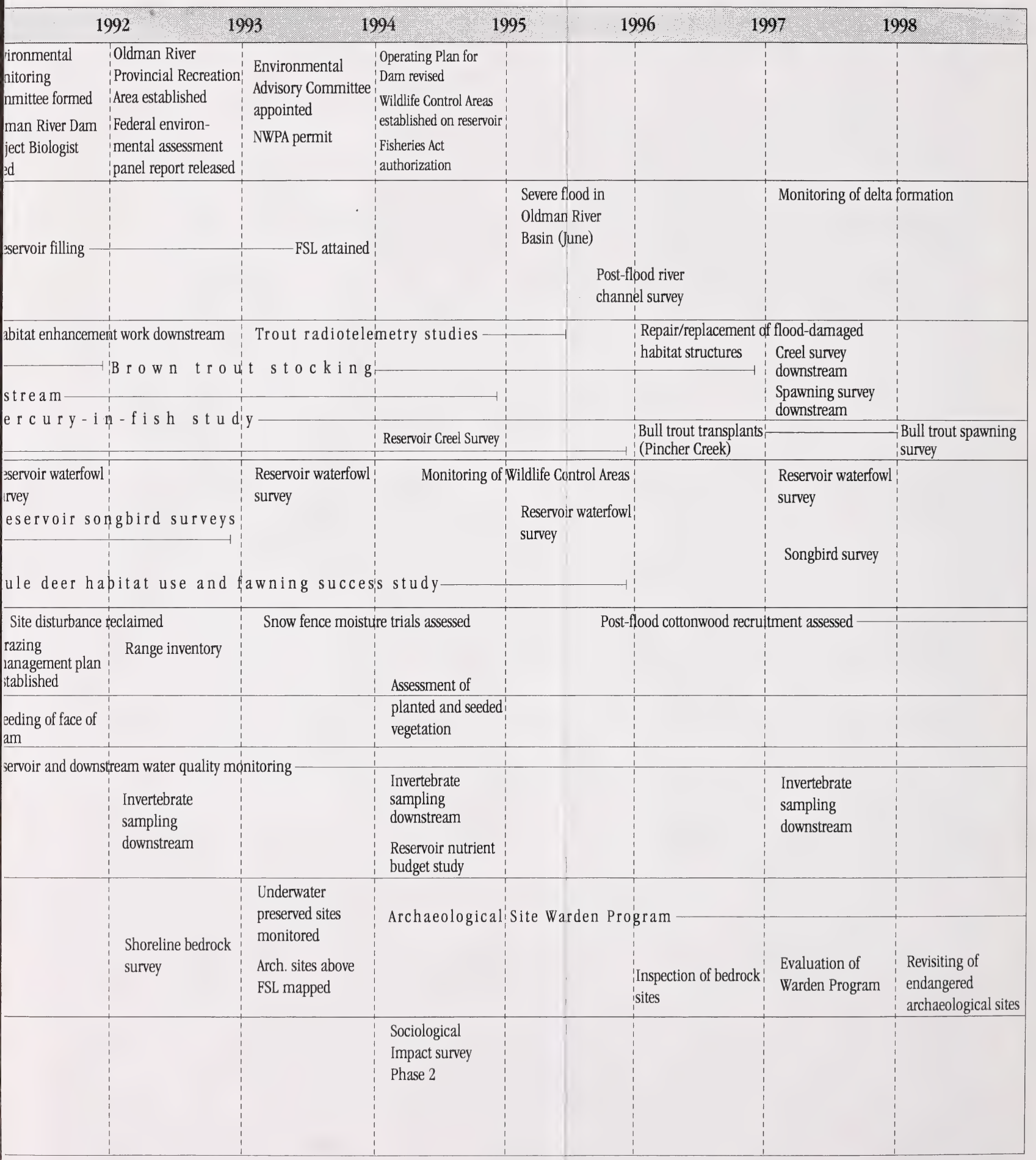




\section{References}

Oldman River Dam Local Advisory Committee. 1993. Final Report and Recommendations to the Ministers of Alberta Public Works, Supply and Services and Alberta Environmental Protection. 34 pp. + App.

\section{The Oldman River Dam and Reservoir}

The Oldman River Dam is located on the Oldman River at the western edge of the semi-arid grasslands in southwestern Alberta (Figure 2). This large dam creates a reservoir which at full supply level covers 2420 ha and inundates approximately $12 \mathrm{~km}$ of the mainstem 0ldman River, $12 \mathrm{~km}$ of the lower Castle River, $7.5 \mathrm{~km}$ of the lower Crowsnest River, and $5 \mathrm{~km}$ of the north fork of the Oldman River (Figure 3).

The Oldman River Reservoir is operated to even out the highly variable flow of the Oldman River. Originating in the mountains, the river and its major tributaries derive most of their flow from snowmelt. About $60 \%$ of this flow occurs between mid-May and mid-July, while the lowest flows occur from late July to October. The reservoir stores water during periods of high runoff and releases it during periods of lower natural flows. With a storage capacity of 490,000 cubic decameters (400,000 acre-feet), it has substantial year-to-year carryover capacity. The reservoir is operated to meet the consumptive water needs of urban and rural communities, irrigation, and industry as well as the non-consumptive needs of the downstream river ecosystem (see Operation of the Dam). Although the primary function of the dam and reservoir is not to control flooding, they may, depending on water levels in the reservoir, be operated to ameliorate or delay downstream flooding.

\section{Figure 2}

Location of the Oldman River Dam

The small box located near Lethbridge represents the map area shown below.
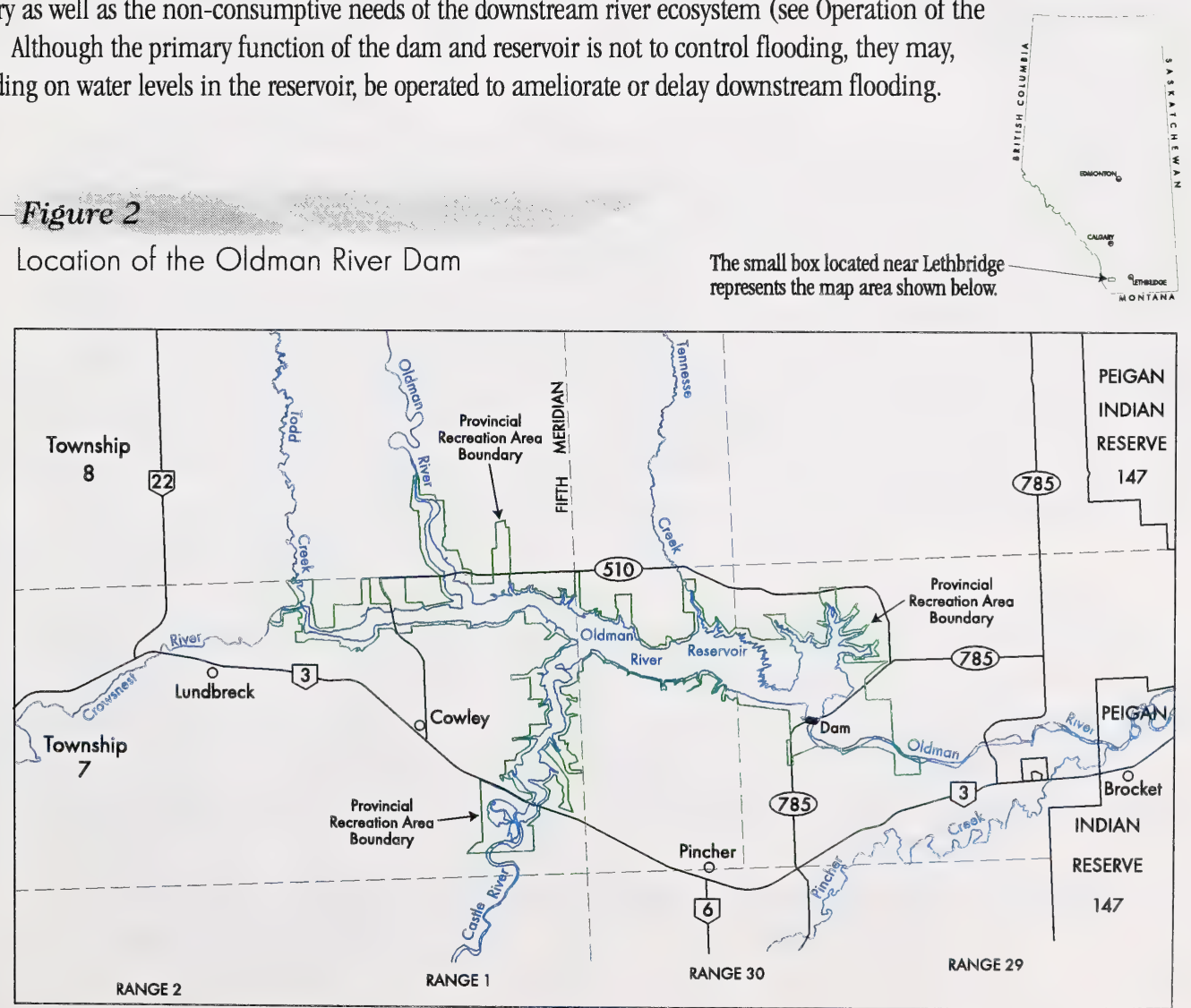


\section{Figure 3}

The Oldman River System

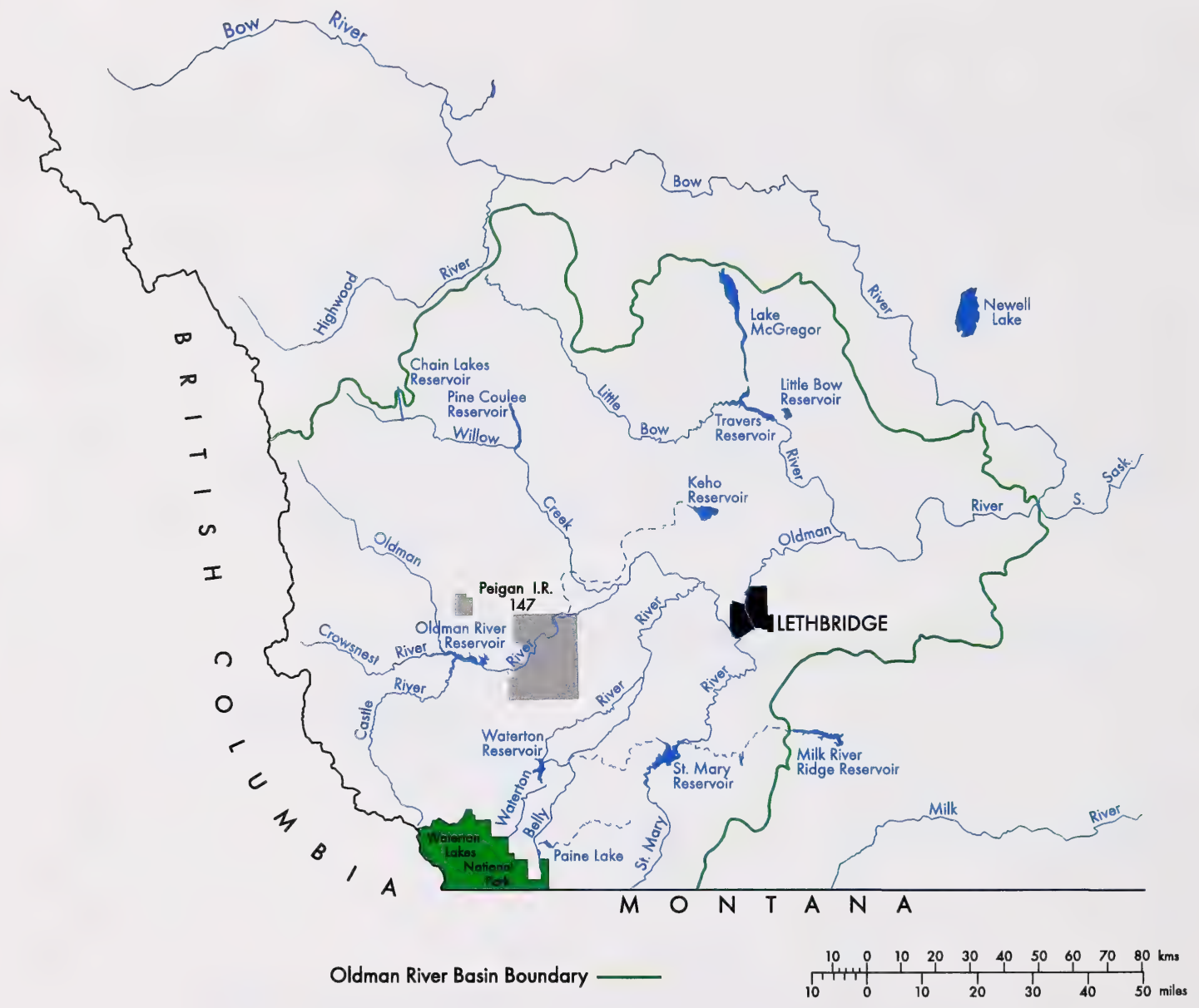




\section{Background}

\section{Initial Concerns}

Southwestern Alberta is richly endowed with historic and prehistoric sites. The flooding of the river valleys within the reservoir's boundaries would result in an irretrievable loss of information about the history of the region. There was also a possibility of damage to historical resources just above the full supply level (FSL) of the reservoir.

\section{Full supply level (FSL)}

the elevation of the water surface when the reservoir is considered full for operational needs

\section{Mitigative Action}

An Historical Resources Impact Assessment and Mitigation Program was undertaken in compliance with the Historical Resources Act and with the advice and involvement of the Historical and Archaeological Subcommittee of the Local Advisory Committee. The assessment and mitigation program dealt with three subjects: palaeontology, prehistory (archaeology), and history.

Palaeontology: The entire future reservoir area was surveyed by palaeontologists. Bedrock was mapped and samples of all fossils found were taken. There were no significant fossil discoveries.

Prehistory (archaeology): The archaeological program for the 0ldman River Dam project was the largest historic resource information recovery program ever undertaken in western Canada. Initial inventories identified some 314 prehistoric sites of which 170 were in the reservoir area. The sites were prehistoric camps, bison kills, and stone feature sites (e.g. tipi rings). No burials or sacred sites were discovered. Mitigative studies, ranging from mapping of surface features to intensive archaeological excavation at the more significant locations, were conducted on all affected sites. The results of these studies have been documented in several reports, and the work has been the subject of many academic papers and public presentations. Public and school tours were conducted while the excavations were taking place and a volunteer program was organized to allow and encourage public involvement in the study of heritage resources.

History: Forty-six historic period sites were identified in the project area. These included occupied and abandoned buildings and sites representing ranches, farms, homesteads, sawmills, roads, bridges and railway grades. Several approaches were used in the mitigation of impacts to these resources. These included:

$\llcorner$ detailed photography and architectural recording of several of the most significant buildings

$\llcorner$ relocation of four of the most significant historic buildings, two to a local museum, and two to "Heritage Acres," an antique equipment club site. Another historic building was protected and preserved in its original location

$\llcorner$ archaeological investigations at some of the most significant historic sites to add to our knowledge of early European settlers in the area 
- detailed research into the history of the area, involving interviews with local residents, resulting in a popular history book, "Where the Rivers Meet"

$\llcorner\quad$ a video record of the natural and cultural history of the area prior to the project

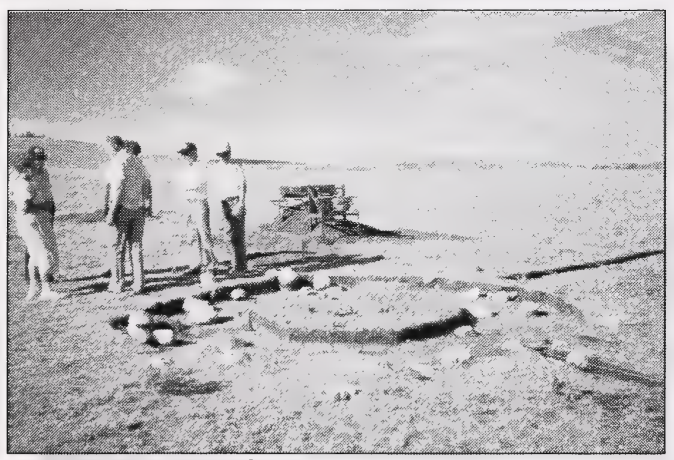

Historical Resources Subcommittee at an excavated tipi ring

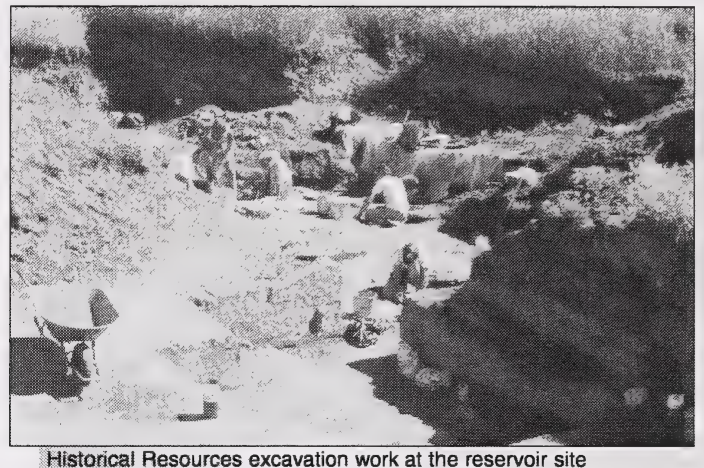

Historical Resources excavation work at the reservoir site

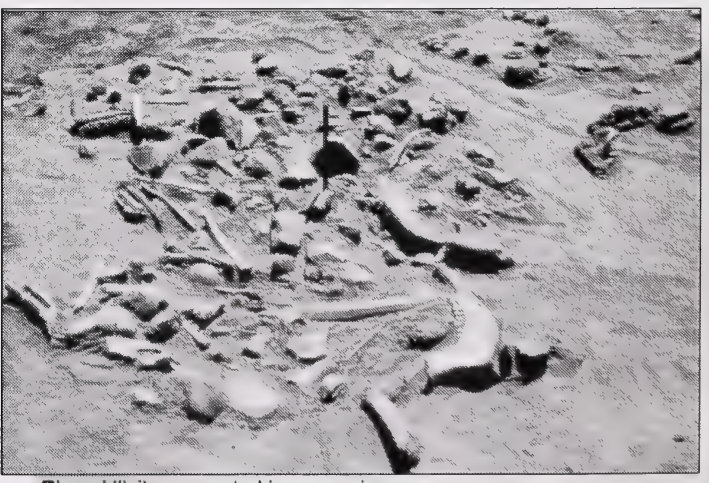

Bison killsite excavated in reservoir area 


\section{Monitoring}

Once the reservoir began to fill, attention turned to resources around the reservoir's edge. Some sites were considered to be in danger of being lost due to wave erosion or slumping of the sedimentary rock around the reservoir.

\section{What Was Done}

Bedrock palaeontology: Although the baseline survey of bedrock outcrops in the reservoir area did not yield any significant fossil discoveries, fossil-bearing outcrops could still become exposed by erosion or slumping of material in the reservoir. Bedrock outcrops along the reservoir shoreline were examined in 1992 and a more detailed inspection of the potential sites identified was conducted in 1996.

Historical resources monitoring: A professional archaeologist examined and described the contents of 59 previously identified sites above FSL, rating each according to the degree of physical threat to its existence. The sites were mapped in preparation for the Archaeological Site Warden Monitoring Program.

Archaeological Site Warden Program: This novel volunteer warden monitoring program was designed by the Archaeological Survey of the Provincial Museum of Alberta in 1994 in an attempt to involve local amateur archaeologists in helping to preserve heritage sites. The reservoir shoreline was divided into 32 segments based on the Historical Resources Monitoring Program and volunteer participants were sought from within the region to take responsibility for these shoreline stretches. Participants were found for 28 of the 32 segments. After attending training sessions, each participant was given an Archaeological Site Warden's Manual and assigned a segment of the reservoir shoreline. Along this segment the warden inspects known sites periodically (at least annually), records any new sites which have become exposed, and makes recommendations about site preservation.

This program, unique to Alberta, was considered a pilot program that might prove useful elsewhere in the province. It was evaluated in 1997 by means of questionnaires sent to the volunteer wardens and a review of wardens' reports.

Underwater preserved sites: These sites were monitored by the Alberta Underwater Archaeological Society in 1992 and 1993.

\section{What Was Found}

Historical resources: Six sites around the reservoir were rated as high priority for further monitoring based on the likelihood of damage from erosion. Nineteen additional sites were rated as moderate and 34 as low priority. These endangered sites are being revisited and documented in 1998.

Archaeological Site Warden Program: The Archaeological Site Warden Program proved to be very useful for providing notification about physical threats to the sites. Several possible new sites have also been identified by wardens. Certain aspects of the program were found to be in need of modification, including the reporting system, communication between the wardens and professional archaeologists, and warden access to equipment.

Reapportionment of certain assigned reservoir segments was also recommended. These adjustments to the program are being made and the site disturbance problems reported by wardens are being resolved. 
Underwater preserved sites: Underwater investigations found no obvious damage from flooding to large features such as tipi rings. Some buried features were disturbed; however, this may be the result of continued recreational and agricultural use of the land following site preparation and before inundation. It is too early to study what effects chemical changes in the soil and water may have on these materials. These effects may be investigated in the future.

\section{Monitoring Timeline and Budget}

From 1992/93 through 1997/98 the historical resources component received $\$ 55,500$.

\begin{tabular}{|c|c|c|c|c|c|c|c|c|}
\hline & $90 / 91$ & $91 / 92$ & $92 / 93$ & $93 / 94$ & $94 / 95$ & $95 / 96$ & $96 / 97$ & $97 / 98$ \\
\hline $\begin{array}{l}\text { Historical Resources } \\
\text { Monitoring Program }\end{array}$ & & & $\mathrm{D} / \mathrm{R}$ & & & & & \\
\hline Warden Program & & & & $\mathrm{D}$ & $\mathrm{D}$ & D & $\begin{array}{c}\mathrm{D} \\
\mathrm{R}^{*}\end{array}$ & \\
\hline Underwater Arch. & $\mathrm{D} / \mathrm{R}$ & & $\mathrm{D} / \mathrm{R}$ & $\mathrm{D} / \mathrm{R}$ & & & & \\
\hline Bedrock Paleontology & & $\mathrm{D} / \mathrm{R}$ & & & $\mathrm{D} / \mathrm{R}$ & & & \\
\hline
\end{tabular}

\section{Monitoring Reports}

Archaeological Survey, 1994. Oldman River Reservoir Historical Resources Monitoring Program. Archaeological Site Warden Manual. Alberta Community Development, Provincial Museum of Alberta, Edmonton. 22 pp. + App.

Fedirchuk McCullough \& Associates Ltd. 1994. Oldman River Reservoir Historical Resources Monitoring Program (ASA Permit 93-53). Prep. for Alberta Environment, Edmonton. 20 pp. + App.

Godfrey, S. 1996. Palaeontological and Erosional Review of Bedrock Exposures within the Periphery of the Oldman River Reservoir. 29 pp.+ App.

Langley, S.B.M. 1993. Oldman River Dam AUAS Monitoring Project: First Year Monitoring. Prep. for Alberta Public Works, Supply and Services, Edmonton. 26 pp.+App.

Langley, S.B.M. 1994. Oldman River Dam AUAS monitoring project: Second year monitoring report. Prep. for Alberta Environment, Edmonton. 26 pp.+ App.

Peck, T.R. 1997. Oldman River Reservoir Historical Resources Monitoring Program Summary and Assessment 1997. 34 pp.+ App. 


\section{References and Other Selected Reports ${ }^{1}$}

Bison Historical Services Ltd. 1990. Section 3.0, 1989 Oldman River Dam Prehistoric Archaeology Mitigation Program. Campsites Component. ASA Permit 89-25. Final Report. Vols. I, II and III. Prep. for Alberta Public Works, Supply and Services, Edmonton.

Carbex Geological Services Ltd. 1987. Paleontological Assessment for the Oldman River Dam, Mitigation/Opportunities Plan. Vols A, B, and C. Prep. for Alberta Public Works, Supply and Services, Edmonton.

Dau, B.J. 1997. Oldman River Dam Prehistoric Archaeology Mitigation Programme, Technical series No. 3. Stone Features Study. Prep. for Alberta Public Works, Supply and Services, Edmonton. 473 pp.

Environmental Management Associates. 1991. 1990 Oldman River Dam Historic Resources Impact Mitigation. Historic Sites Component. ASA Permit 89-44. Final Report. Vols 1 and 2. Prep. for Alberta Public Works, Supply and Services, Edmonton.

Environmental Management Associates. 1991. 1990 0ldman River Dam Prehistoric Archaeology Mitigation Program. Killsites Component. ASA Permit 90-27. Final Rept. Vols I and II. Prep. for Alberta Public Works, Supply and Services, Edmonton.

Ethos Consultants Ltd. 1989. 1988 0ldman River Dam Prehistoric Archaeology Mitigation Program. Stone Features Component . ASA Permit 88-34. Final Report. Prep. for Alberta Public Works, Supply and Services, Edmonton. 367 pp.

Kennedy, M. 1986. Phase II Archaeological and Historical Resources Study Oldman River Dam Vol. I: Historic Period Resources Impact Assessment.

Kennedy M. and B.0.K. Reeves. 1986. Archaeological and Historical Resources Study Oldman River Dam. Vol. I Part I, Historic Period Resources Inventory and Impact Assessment. Prep. for Alberta Public Works, Supply and Services, Edmonton. 326 pp.

Landals, A. 1993. Oldman River Dam Prehistoric Archaeology Mitigation Programme, Technical series No. 2. Killsites Study. Prep. for Alberta Public Works, Supply and Services, Edmonton. 287 pp.+App.

Langley, S.B.M. 1991. Oldman River Dam AUAS Monitoring Project: Final Report (ASA Permit 90-58). Prep. for Alberta Public Works, Supply and Services, Edmonton. 43 pp.+App.

Potyondi, B. 1992. Where the Rivers Meet. Robins Southern Printing (1990) Ltd., Lethbridge, AB. 217 pp.

Reeves, B.0.K. 1987. Oldman River Dam Phase II Archaeological and Historical Resources Inventory and Assessment. Vol. II. Prehistoric Sites Part 1. Prep. for Alberta Public Works, Supply and Services, Edmonton. Van Dyke, S. 1994. Oldman River Dam Prehistoric Archaeology Mitigation Programme, Technical series No. 1. Campsites Study. Prep. for Alberta Public Works, Supply and Services, Edmonton. 349 pp.

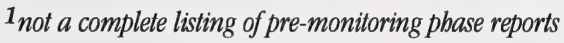




\section{Geophysical and Hydrological Resources}

\section{Background}

\section{Initial Concerns}

A large reservoir may have a number of geophysical and hydrological impacts. As the velocity of a river flowing into a reservoir decreases, the sediment load carried by the water is dropped and eventually forms a delta. In some instances, such deltas may block fish movement into and out of the reservoir. Finer suspended sediments are carried into the reservoir and deposited against the face of the dam. The reservoir gradually infills to the point where it is no longer useful. Having lost its sediment load in the reservoir, the river downstream of the dam picks up new material from the river bed. Degradation of the river channel occurs until a new stable river profile is achieved.

A large reservoir may affect groundwater in the surrounding area and may cause seismic activity. Earthquakes occurring from natural causes may cause damage to the dam.

The following predictions were made for the Oldman River Dam and Reservoir:

$L$ The effective lifespan of the reservoir is in the hundreds of years.

$L$ The Oldman River bed would be degraded to a depth of about $0.5 \mathrm{~m}$ for a distance of less than $2 \mathrm{~km}$ downstream of the dam. This process was expected to take approximately 25 years.

$L$ Deltas would form in the Castle and North Fork Oldman arms of the reservoir but not in the Crowsnest Arm, as the Crowsnest River carries little sediment. It was assumed that delta formation would not block fish movement into any of the three rivers.

$\llcorner$ It is possible, but unlikely, that reservoir-induced seismic events would occur at the reservoir.

\section{Mitigative Action}

Reservoir sedimentation and downstream degradation: Cross sections of each inflowing tributary were surveyed in 1985 to provide a baseline for further monitoring of sediment deposition. Cross sections of the river channel over the first 7 kilometres downstream of the dam were also surveyed at this time; however, dam construction and realignment of the river channel made it necessary to resurvey this reach.

Groundwater: Beginning in 1985, an extensive system of piezometers was installed around the perimeter of the reservoir and downstream. These have been used for taking groundwater measurements at regular intervals.

piesometer open-ended test well

Seismic activity: Two seismic systems were put in place for monitoring seismic activity near the Oldman River Dam

$\llcorner$ two strong motion accelerometers to monitor ground accelerations at the dam site and the response of the dam structure to those motions during potentially damaging earthquakes

$\llcorner$ a three-station seismic array deployed around the reservoir to detect reservoir-induced seismicity. 


\section{Monitoring}

\section{What Was Done}

Groundwater: The main objective of the groundwater monitoring program is to determine what, if any, effects the dam and reservoir have on the groundwater regime adjacent to and upstream of the dam. Water levels in 40 observation wells are monitored on a monthly basis and one on a daily basis.

Reservoir sedimentation: Long-term monitoring of reservoir sedimentation is done in order to obtain an accurate estimate of the effective lifespan of the reservoir. Monitoring of the progress, rate and volume of sediment deposition in the reservoir near the entrance of the three major tributaries is accomplished by comparison of cross sectional surveys over the years. In 1997/98 river cross-sections were surveyed on the Castle River Arm of the reservoir. Cross sections on the north fork of the Oldman River are planned for 1998/99.

Downstream channel: Monitoring of the river channel downstream of the dam is done to identify any changes that have taken place in the river channel bed. In 1995 and 1996 cross sections downstream of the dam were resurveyed to allow comparisons to a 1987 survey.

Monitoring seismic activity: The seismic systems are monitored by Alberta Environmental Protection. The strong motion monitoring system is accessed remotely by a computer in Edmonton at one- to two-week intervals throughout the year.

\section{What Was Found}

\section{Reservoir deposition}

Deposition at the entrance of the tributaries to the reservoir is proceeding as predicted. The deposition that has occurred in the Castle Arm of the reservoir is shown in Figure 4.

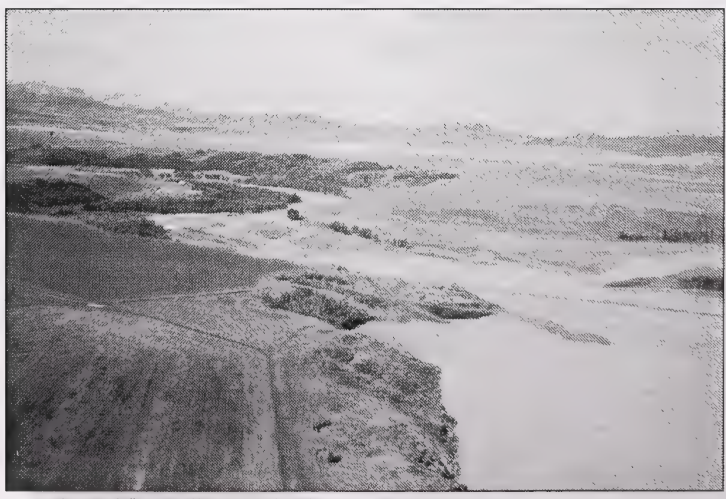

Inflow of Castle River to the Oldman River Reservoir 


\section{Figure 4}

Cross sectional view of the Castle River channel just upstream of the Reservoir

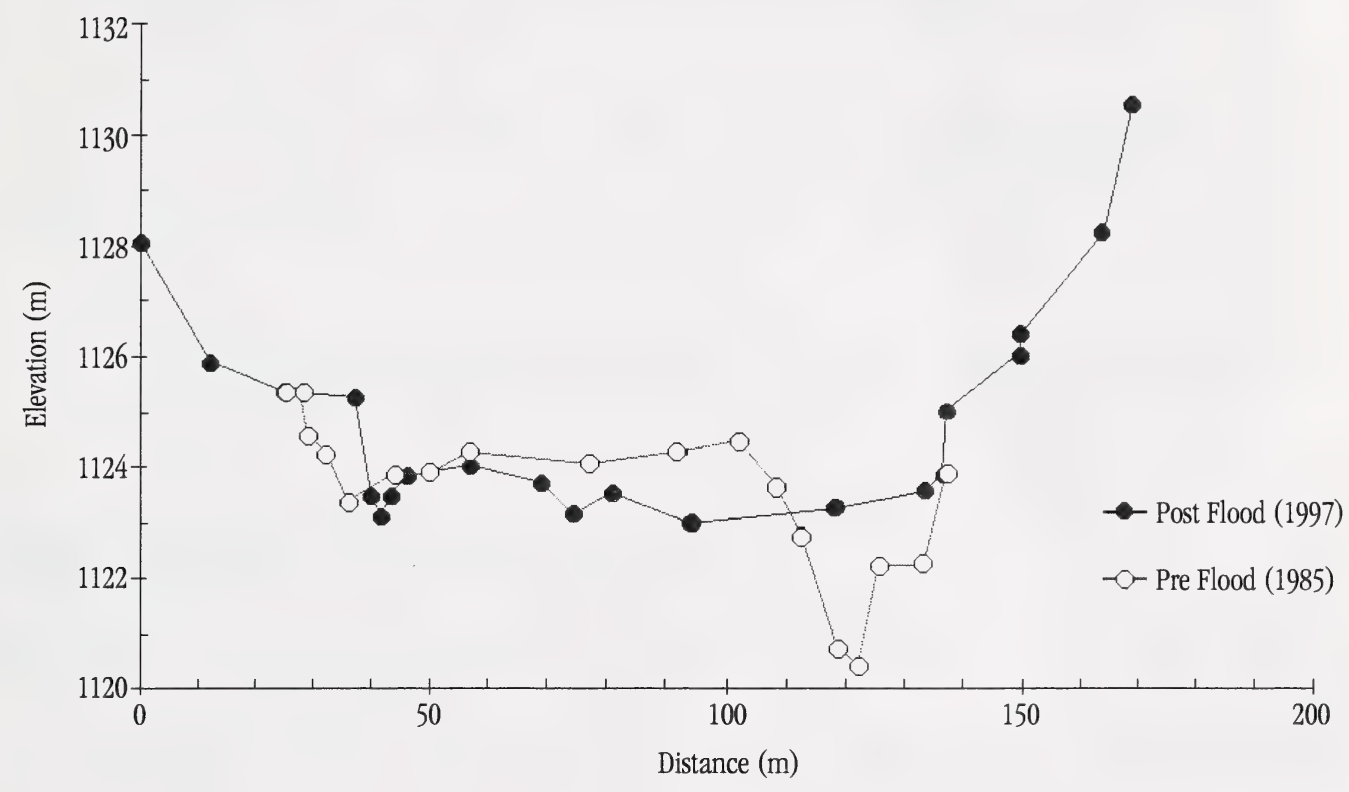


Downstream channel: Although the Oldman River bed has been going through aggradation/degradation since 1987, most of the degradation occurred during or as a result of the 1995 flood. In one area the erosion is over three metres deep (Figure 5). In general the river channel downstream of the dam is expected to continue to degrade until sediment load, flow velocities and river gradient balance out.

\section{Figure 5}

Oldman River thalweg profiles between Cottonwood and Summerview bridges, 1987,1995 and 1996

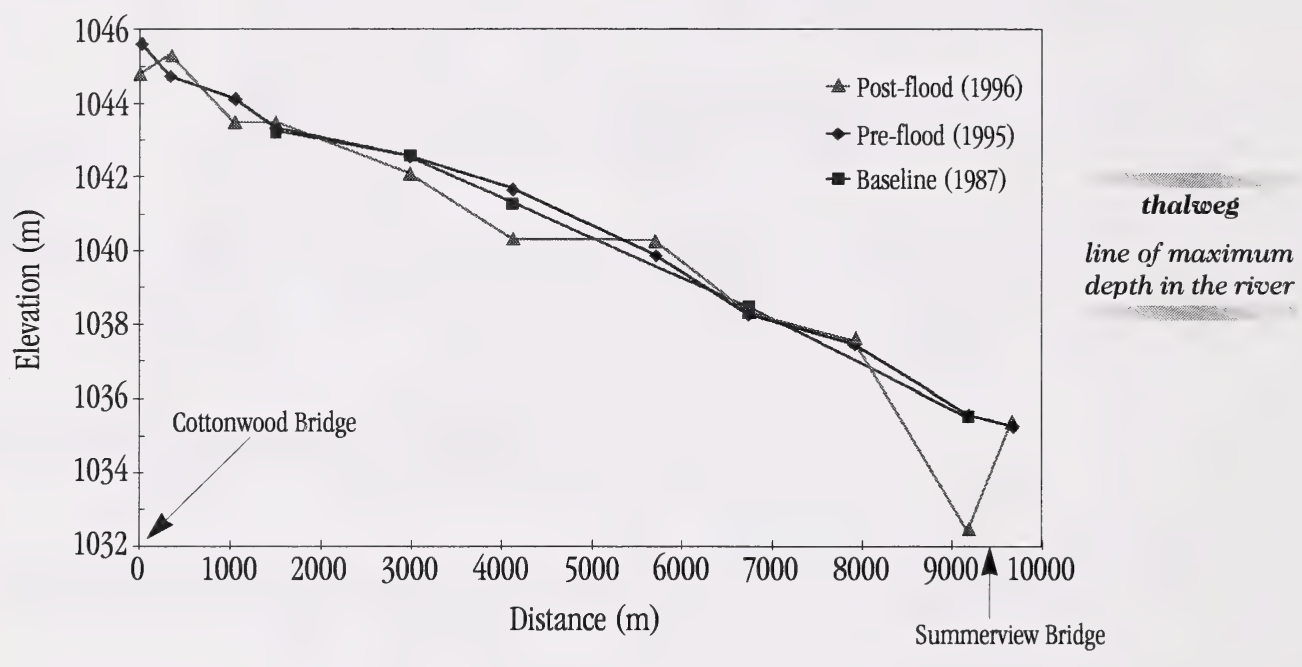

Groundwater: The hydraulic conductivity of the surficial deposits and bedrock aquifers in the vicinity of the reservoir is low. Only six out of 40 wells have demonstrated a direct hydraulic connection between the aquifers in which the wells were completed and the Oldman River Reservoir.

Seismic activity: As of 1995, no earthquake events large enough to trigger the strong motion accelerometers had occurred in the region nor had any reservoir-induced seismic events occurred. As reservoir-induced seismic events are most likely to happen during the few years immediately after impoundment, and in the interest of reducing costs, the equipment to detect reservoir-induced events was dismantled in 1995. The strong motion accelerometers are still being monitored. 


\section{Monitoring Timeline and Budget}

From 1992/93 through 1997/98 this component received $\$ 10,000$.

\begin{tabular}{|l|c|c|c|c|c|c|c|c|}
\hline & $91 / 92$ & $92 / 93$ & $93 / 94$ & $94 / 95$ & $95 / 96$ & $96 / 97$ & $97 / 98$ & $98 / 99$ \\
\hline Groundwater & $\mathrm{D} / \mathrm{R}$ & $\mathrm{D} / \mathrm{R}$ & $\mathrm{D} / \mathrm{R}$ & $\mathrm{D} / \mathrm{R}$ & $\mathrm{D} / \mathrm{R}$ & $\mathrm{D}$ & $\mathrm{D}$ & \\
\hline Reservoir sedimentatn & & & & & & $\mathrm{D}$ & & $\mathrm{D}$ \\
\hline Downstream channel & & & & $\mathrm{D} / \mathrm{R}$ & $\mathrm{D} / \mathrm{R}$ & & & \\
\hline Seismicity & $\mathrm{D} / \mathrm{R}$ & $\mathrm{D} / \mathrm{R}$ & $\mathrm{D} / \mathrm{R}$ & $\mathrm{D} / \mathrm{R}$ & $\mathrm{D} / \mathrm{R}$ & $\mathrm{D} / \mathrm{R}$ & & $\mathrm{P}$ \\
\hline
\end{tabular}

D - data collected $\quad \mathrm{R}$ - report completed $\quad \mathrm{P}$ - Proposed monitoring

\section{Monitoring Reports}

Bingham, D.K. 1994. Seismic Monitoring near Oldman River Dam: Progress Report 1991-1993. Hydrogeology Br, Alberta Environmental Protection. 9 pp.

Bingham, D.K. 1995. Seismic Monitoring near Oldman River Dam: Progress Report 1994. Hydrogeology Br, Alberta Environmental Protection. 8 pp.

Bingham, D.K. 1996. Seismic Monitoring near Oldman River Dam: Progress Report 1995. Hydrogeology Br, Alberta Environmental Protection. 4 pp.

Persram, A.S. 1996. Groundwater Monitoring Program and Reservoir Effects on the Groundwater Regime at the Oldman River Damsite - 1995. Alberta Environmental Protection, Water Sciences Branch, Calgary. 3 pp + charts.

\section{References and Other Selected Reports ${ }^{1}$}

Northwest Hydraulic Consultants Ltd. 1987. Oldman River Dam. Preliminary Engineering Report. Appendix C. River morphology and sedimentation. Prep. for Alberta Environment. $24 \mathrm{pp}$.

Northwest Hydraulic Consultants Ltd. 1988. Oldman River Dam: Potential Downstream Effects on Sediment Regime of Oldman River and Tributaries. Prep. for Alberta Environment. 19 pp.+ App.

$1_{\text {not a complete listing of pre-monitoring phase reports }}$ 


\section{Background}

\section{Initial Concerns}

The impoundment of a river may greatly alter its water quality. Within the newly formed reservoir, sediments previously suspended by river currents settle, nutrients and chemicals from inundated soils and plants may be released into the water, dissolved oxygen levels may change, and plankton populations may increase. An environmental instability results that may persist for many years until a new ecological balance develops. These conditions may affect development of a reservoir fishery and recreational use of the reservoir.

Impoundment may also affect downstream water quality. For example, when water is released from the hypolimnion, as in the case of the Oldman River Dam, downstream river temperatures may be altered: spring warming and fall cooling may be delayed, and temperatures may be lower in summer and higher in winter than

hypolimnion

bottom layer of a body of water normal. Another influence is the quantity of water released, i.e. the regulated flow volume. This affects levels of dissolved oxygen, nutrients and contaminants. All of these changes may exert impacts on the river's biotic communities. Water temperature, dissolved oxygen and ammonia levels are critical to the survival of fish.

\section{Mitigative Action}

There are no feasible means of mitigating the effects of the presence of the Oldman River Dam and Reservoir on downstream water quality. However, water quality requirements played an important role in the design of an operational plan for the dam. To define these requirements, the preliminary (1989) operating plan for the dam was evaluated using computer simulation modelling. The output predicted the resulting water temperatures and circulation in the reservoir. This information was then used to simulate downstream water quality. The major downstream factors examined were temperature, dissolved oxygen, and ammonia levels. Low flows and effluents from municipalities and industry were also taken into account. Increased flows from the operation of the reservoir were also simulated. Based on these studies, water quality instream needs estimates were revised and are now part of the current operating guidelines for the dam (see 0peration section).

A number of predictions about the reservoir and downstream water quality emerged from this process:

$\llcorner$ The reservoir will undergo a minor trophic upsurge of 2-4 years' duration, after which it will stabilize in the oligotrophic to oligomesotrophic range of productivity.

$\llcorner$ The reservoir will trap $96 \%$ of inflowing sediment.

\section{instream needs}

the water quality and quantity required to protect aquatic and riparian environments and meet the ecological needs within the river

\section{dissolved oxygen (DO)}

the amount of oxygen dissolved in water

DO levels affect the distribution of fish and other aquatic organisms. Normally, DO is high in rivers in the headwaters of the eastern slopes because of the turbulence of the streams, their low productivity, and their cold temperatures. As these rivers flow eastward, the water temperature increases and they become more productive. In summer, DO levels in downstream reaches show dramatic diurnal cycling, rising during the day and falling after dark. 
$k$ Suspended sediment in the reservoir may be elevated slightly during the initial filling due to shoreline erosion.

$\llcorner$ Temperatures at the outlet will depend on water levels in the reservoir and will therefore vary between years.

$\llcorner$ There will be no significant oxygen depletion in the hypolimnion.

$\llcorner$ The dam will result in improved overall water quality downstream through its ability to augment low flows.

$\llcorner$ River temperatures downstream as far as the Belly River confluence will be lower than normal in spring and summer and warmer in fall and winter.

$L$ Temperature differences between upper and lower reaches of the river below the dam will be as great as $15^{\circ} \mathrm{C}$ (as compared with historical differences of $4^{\circ} \mathrm{C}$ ).

$\llcorner$ Despite the loading of organic material from the Lethbridge sewage treatment plant (which causes plant growth and reduced oxygen levels at night due to plant respiration), dissolved oxygen will not go below $5 \mathrm{mg} / \mathrm{L}$ downstream of Lethbridge if minimum flows are maintained at or above $20 \mathrm{~m}^{3} / \mathrm{s}$ in summer. In winter, the minimum flow required downstream of Lethbridge to protect water quality is $11.5 \mathrm{~m}^{3} / \mathrm{s}$.

$\llcorner$ Under stratified reservoir conditions, a slight increase in dissolved phosphorus, ammonia, nitrate and organic carbon directly downstream from the dam may occur due to release from the hypolimnion.

$\llcorner$ Benthic algae will become more abundant downstream of the dam due to higher winter temperatures and more stable flows.

$\llcorner$ Increased irrigation return flow could increase levels of pesticides, nutrients, salinity and suspended sediment in the Oldman River.

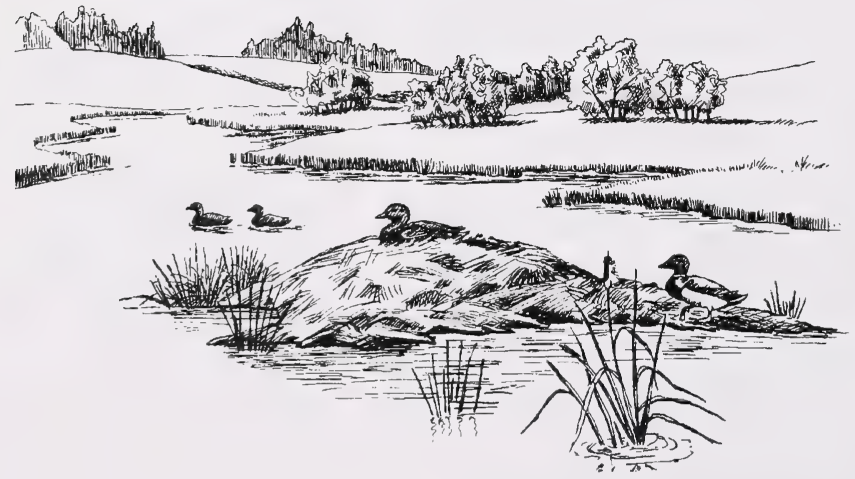

\section{productivity}

the capacity of a waterbody to support the growth of aquatic plants and animals.

Oligotrophic waterbodies have low productivity; mesotrophic, moderate productivity and eutrophic, high productivity.

trophic upsurge

increase in productivity of a newly formed waterbody such as a reservoir due to nutrient release from inundated soils and plants. This is followed by a decline in productivity as nutrients are used up. 


\section{Monitoring}

The water quality of the reservoir and downstream river has been monitored to obtain data for testing the accuracy of predictions made with water quality models. These models can then be refined to yield better predictions of the water quality that would result from altered flow regimes or other conditions within the watershed. Water quality is also being monitored to identify any changes that might be of concern for fisheries or human use and to obtain information on how tributaries and point source discharges are affecting the river water quality during low flow conditions. Much of this information is required under the Navigable Waters Protection Act authorization and Fisheries and Oceans Canada authorization (Appendices D and E).

\section{What Was Done}

Reservoir monitoring: Water quality in the 0ldman Reservoir was monitored after the reservoir began filling in 1991 through 1996 to determine whether water in the reservoir was suitable for its intended uses and whether trophic upsurge was occurring. Composite samples were collected from an area near the dam (Cell I) and from the main part of the reservoir further west (Cell II; Figure 6) for major ions, hardness, alkalinity, nutrients, carbon and residues. Water was sampled monthly between May and October each year from both cells. Temperature, dissolved oxygen, $\mathrm{pH}$ and conductivity were measured at $1 \mathrm{~m}$ or $5 \mathrm{~m}$ depth intervals from the surface to the bottom. As well, nutrient samples were taken at the subsurface, middle and bottom depths. Sediment samples were also collected from the bottom at several locations in 1991-3 and 1996 to determine sediment chemistry, including levels of mercury. Phytoplankton and zooplankton samples were collected from the two basins on each sampling trip.

Starting in 1994, the three inflowing rivers were sampled monthly during the open-water season to assess their water quality and potential impact on the reservoir and to calculate a nutrient budget for the reservoir. Total phosphorus was also sampled in these rivers in 1992 to enable a preliminary phosphorus budget to be calculated for the reservoir.

Downstream monitoring: Sampling of downstream river quality began at the same time as the reservoir water sampling program. During the first few years, data were collected on river flows, water temperature, suspended solids, total gas pressure, dissolved oxygen, dissolved phosphorus, ammonia, benthic algae and major ions. Following this, the frequency and duration of sampling were revised as needed. The monitoring sites for water temperature and dissolved oxygen are shown in Table 2 and Figure 7. 
$\geq$
\pm
0
3
0
$\frac{1}{0}$
3
3

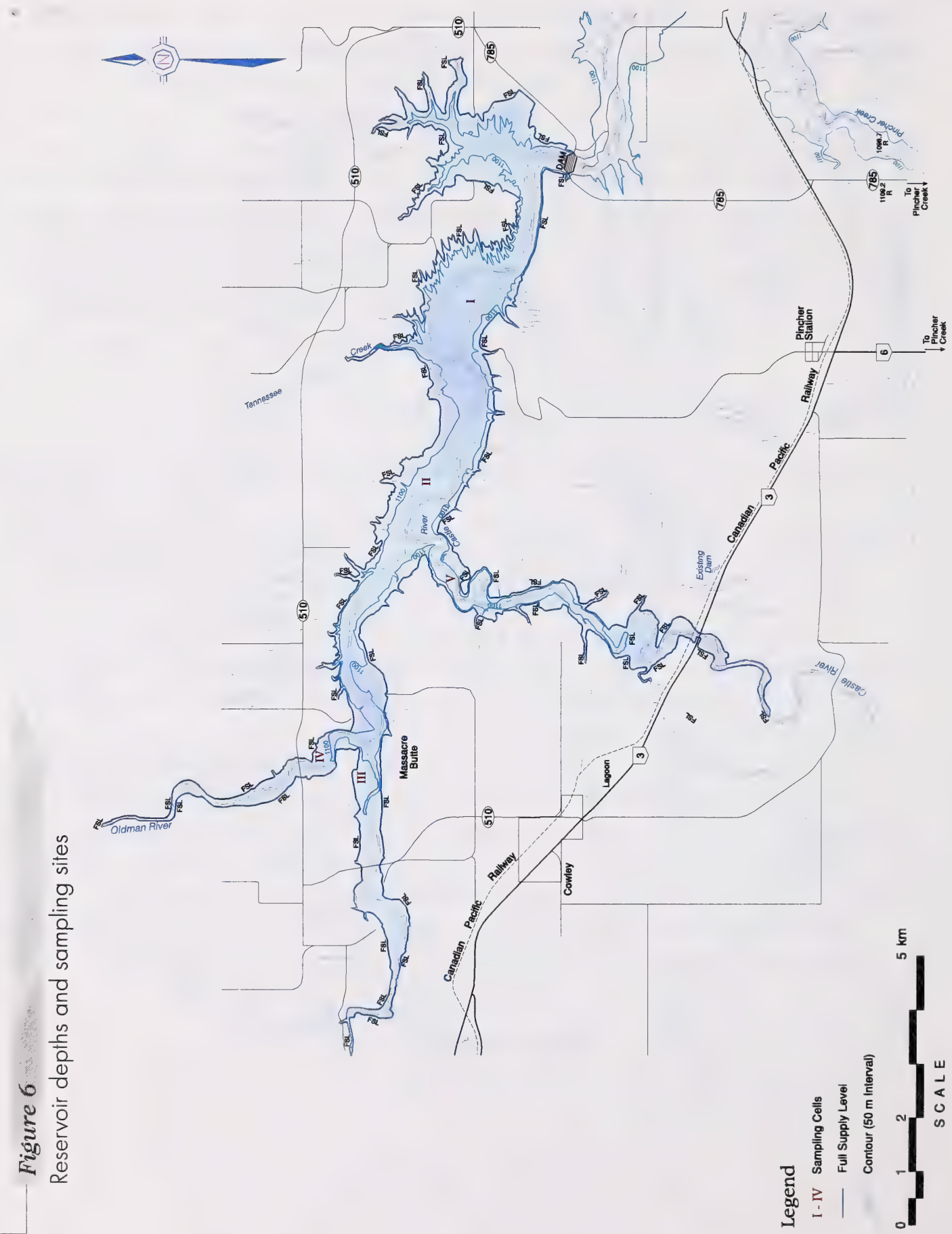




\section{Table 2}

Oldman River temperature and dissolved oxygen monitoring

\begin{tabular}{|c|c|c|c|c|c|c|c|c|}
\hline \multirow[t]{2}{*}{ Oldman River site } & \multicolumn{8}{|c|}{ Years } \\
\hline & 1991 & 1992 & 1993 & 1994 & 1995 & 1996 & 1997 & 1998 \\
\hline $\begin{array}{l}100 \mathrm{~m} \text { downstream of dam } \\
\text { (bottom release) }\end{array}$ & & & & & $\mathrm{T}$ & $\mathrm{T}$ & $\mathrm{T}$ & $\mathrm{T}$ \\
\hline Brocket & $\mathrm{D}$ & $\mathrm{D}$ & & $\mathrm{T}$ & $\mathrm{T}$ & $\mathrm{T}$ & $\mathrm{T}$ & $\mathrm{T}$ \\
\hline Downstream of LNID Weir & & & & $\mathrm{T}$ & $\mathrm{T}$ & $\mathrm{T}$ & $\mathrm{T}$ & $\mathrm{T}$ \\
\hline Downstream of Fort Macleod & $\mathrm{D}$ & $\mathrm{D}$ & & $\mathrm{T}$ & $\mathrm{T}$ & $\mathrm{T}$ & $\mathrm{T}$ & $\mathrm{T}$ \\
\hline Rocky Coulee & & & & & & $\mathrm{T}$ & $\mathrm{T}$ & $\mathrm{T}$ \\
\hline Monarch & & $\mathrm{D}$ & $\mathrm{D}$ & $\mathrm{D} / \mathrm{T}$ & $\mathrm{D} / \mathrm{T}$ & $\mathrm{D} / \mathrm{T}$ & $\mathrm{D} / \mathrm{T}$ & $\mathrm{D} / \mathrm{T}$ \\
\hline Downstream of Belly River & & & & $\mathrm{T}$ & $\mathrm{T}$ & $\mathrm{T}$ & $\mathrm{T}$ & $\mathrm{T}$ \\
\hline Upstream of Lethbridge & & & $\mathrm{D}$ & $\mathrm{D} / \mathrm{T}$ & $\mathrm{D}$ & $\mathrm{D} / \mathrm{T}$ & $\mathrm{D} / \mathrm{T}$ & $\mathrm{D} / \mathrm{T}$ \\
\hline Downstream of Lethbridge & $\mathrm{D}$ & $\mathrm{D}$ & $\mathrm{D}$ & $\mathrm{D}$ & $\mathrm{D} / \mathrm{T}$ & $\mathrm{D} / \mathrm{T}$ & D & $\mathrm{D}$ \\
\hline Highway 845 & & & $\mathrm{D}$ & $\mathrm{D}$ & & & & \\
\hline $\begin{array}{l}\text { Upstream of mouth at } \\
\text { Fincastle }\end{array}$ & $\mathrm{D}$ & $\mathrm{D}$ & $\mathrm{D}$ & $\mathrm{D}$ & & $\mathrm{D} / \mathrm{T}$ & $\mathrm{T}$ & $\mathrm{T}$ \\
\hline
\end{tabular}

\section{What Was Found}

Reservoir: The 0ldman Reservoir has excellent water quality compared with many natural Alberta lakes and contributes high quality water to the Oldman River. It is very low in nutrients and algae (oligotrophic). Levels of phosphorus and chlorophyll $a$ (a measure of the algal population) have not changed significantly since the reservoir began filling in 1991, although there is natural variability from year to year (Table 3). 
$\geq$
\pm 0
0
3
0
1
$\frac{1}{0}$
3

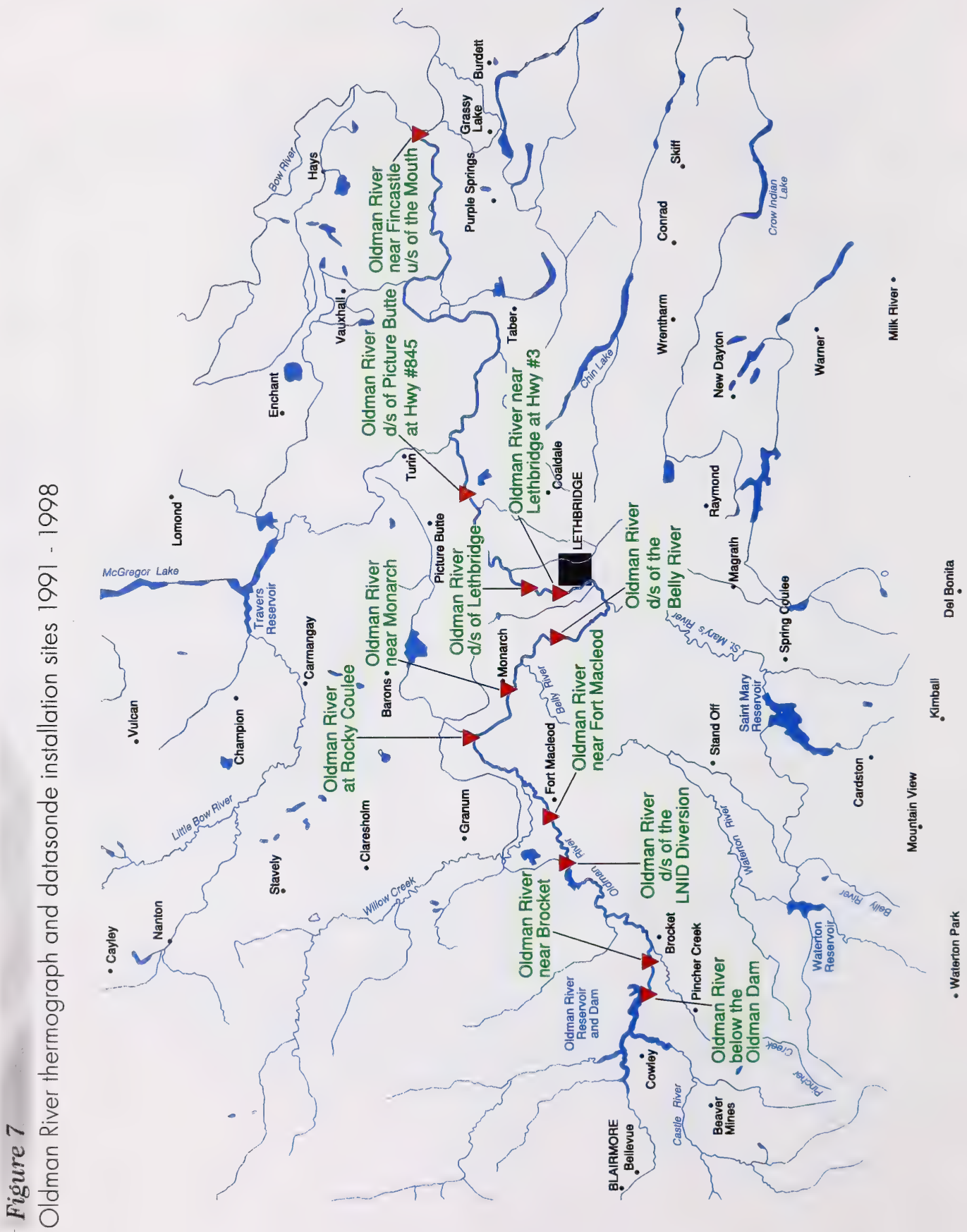




\section{Table 3}

Average concentrations of chlorophyll $a$ and total phosphorus in the Oldman Reservoir 1991 - 1996, May - October euphotic zone composite samples

\begin{tabular}{|l|l|l|l|l|}
\hline Year & \multicolumn{2}{|l|}{ Chlorophyll $a\left(\mathrm{mg} / \mathrm{m}^{3}\right)$} & \multicolumn{2}{l|}{ Total Phosphorus $\left(\mathrm{mg} / \mathrm{m}^{3}\right)$} \\
\hline & Cell I & Cell II & Cell I & Cell II \\
\hline 1991 & 1.44 & 2.98 & 22.4 & 17.6 \\
\hline 1992 & 1.27 & 1.40 & 17.4 & 15.5 \\
\hline 1993 & 2.50 & 2.70 & 15.8 & 14.8 \\
\hline 1994 & 1.17 & 1.40 & 14.9 & 13.9 \\
\hline 1995 & 2.32 & 1.76 & 17.0 & 14.8 \\
\hline 1996 & 1.62 & 0.92 & 13.9 & 15.2 \\
\hline
\end{tabular}

Based on the amount of phosphorus carried by the inflowing tributaries and the river downstream and the amount calculated for other water sources in the reservoir watershed, it appears that release of phosphorus from reservoir bottom sediments (as occurs in many natural Alberta lakes) is not an important contributor to reservoir phosphorus levels. These levels are low and are controlled mainly by external loading from the three tributaries. The low phosphorus concentration is likely a major factor limiting the growth of algae in the reservoir.

There is no evidence of the predicted trophic upsurge. Clearing of topsoil and vegetation from the reservoir area prior to filling is probably one reason why this has not occurred. Also, the reservoir's flushing rate has been relatively high, particularly in 1995 and 1996.

Dissolved oxygen concentrations have remained at or above $6 \mathrm{mg} / \mathrm{L}$ during the open-water period, and as predicted, there is no oxygen depletion in the hypolimnion. Winter oxygen levels have not been measured but are not expected to be much lower as there is little evidence of sediment oxygen demand.
The reservoir shows only slight temperature gradients in the summer and is isothermal in spring and fall.

The reservoir retains about $70-80 \%$ of incoming suspended solids, which is somewhat low for a reservoir of its size and less than that predicted. Water clarity has generally increased over the years although it declines in late spring (as predicted) due to erosion as the reservoir fills.

A technical report on water quality of the reservoir is underway.

Downstream effects: The findings discussed below are based on data collected to 1994. These should be regarded as preliminary, as the reservoir was not completely filled until 1993 (Figure 8). Analyses of post-1994 data are in progress.

Water temperatures below the dam have been cooler in summer than historically as far downstream as Monarch, as predicted. Also as predicted, the water as far as Brocket ( $8 \mathrm{~km}$ downstream) has been warmer in the fall compared with historical conditions. Temperature differences between upper and lower reaches of the river below the dam have increased over historical conditions although not to the extent predicted. 


\section{Figure 8}

Reservoir elevations 1991 - 1993

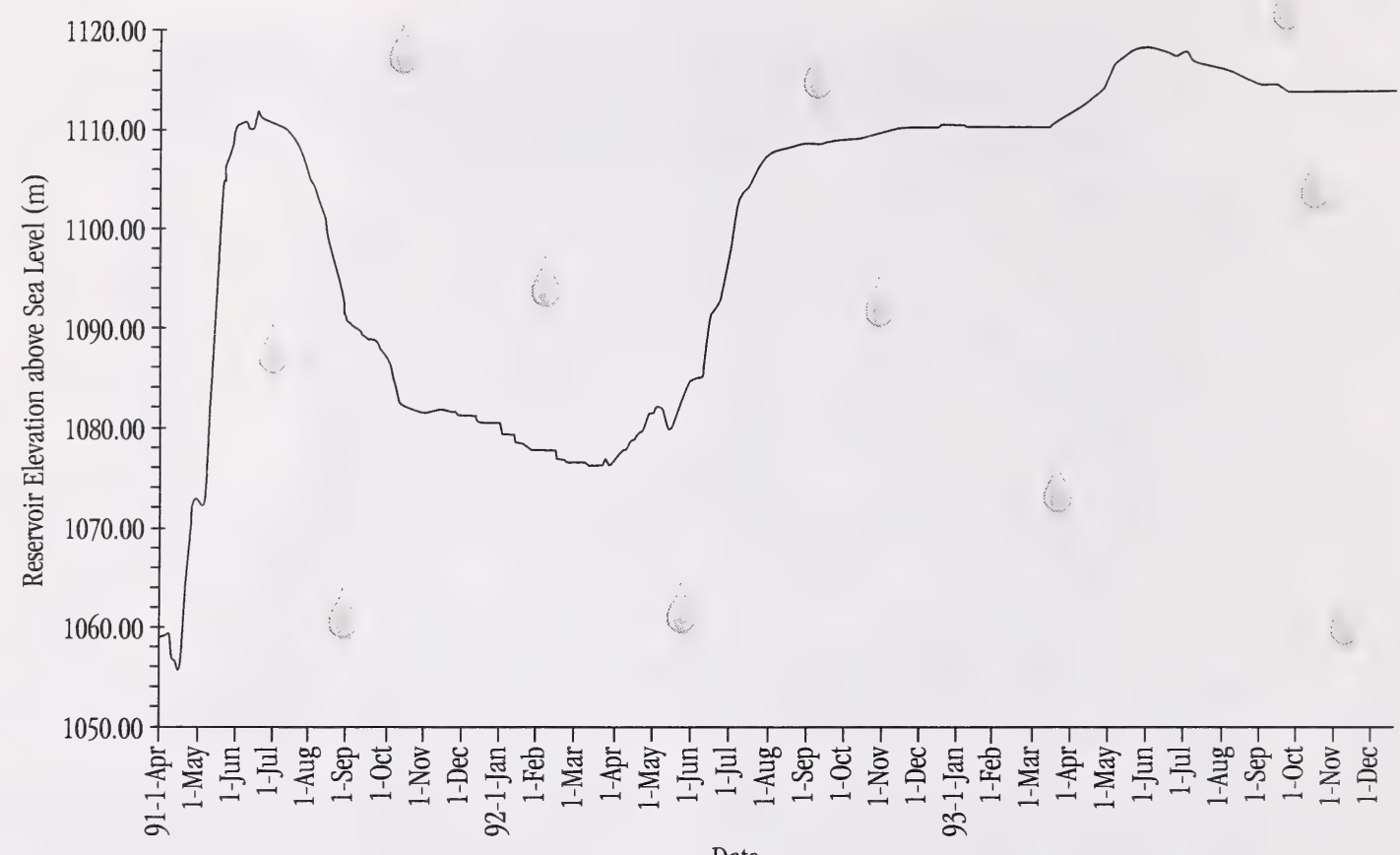

Data collected to 1994 support the prediction that the concentration of dissolved oxygen would remain above $5 \mathrm{mg} / \mathrm{L}$ during the critical warm summer period below Lethbridge if flows remain at or above $20 \mathrm{~m}^{3} / \mathrm{s}$. The requirements of all life stages of brown trout and walleye (the management target fish species) in the reaches of consideration for these species have been met, with the exception that fall spawning of brown trout in the reach near the dam may have been delayed due to the warm temperature of the water.

Suspended solids concentrations are reduced downstream at least as far as Brocket. At Lethbridge and further downstream, levels of suspended sediments have remained within historical ranges.
There appear to be no changes in nutrient levels as far downstream as Lethbridge. Levels of benthic algae at Brocket were substantially higher than historic levels during the summer of 1992. This does not necessarily confirm the predicted increase in algal biomass, as lower than average summer flows occurred in 1992.

Impacts of increased irrigation flows have not been addressed by the monitoring program. Other studies of the impact of irrigation returns in the Oldman River Basin are currently underway. 


\section{Monitoring Timeline and Budget}

From 1992/93 through 1997/98 the water quality monitoring component received $\$ 273,500$.

\begin{tabular}{|l|c|c|c|c|c|c|c|c|}
\hline & $91 / 92$ & $92 / 93$ & $93 / 94$ & $94 / 95$ & $95 / 96$ & $96 / 97$ & $97 / 98$ & $98 / 99$ \\
\hline Reservoir & $\mathrm{D} / \mathrm{R}$ & $\mathrm{D} / \mathrm{R}$ & $\mathrm{D}$ & $\mathrm{D}$ & $\mathrm{D}$ & $\mathrm{D}$ & & $\mathrm{Rp}$ \\
\hline Downstream Effects & $\mathrm{D}$ & $\mathrm{D}$ & $\mathrm{D}$ & $\mathrm{D}$ & $\mathrm{D}$ & $\mathrm{D}$ & $\mathrm{D}$ & $\mathrm{P} / \mathrm{Rp}$ \\
\hline
\end{tabular}

$\mathrm{D}$ - data collected $\mathrm{R}$ - report completed $\mathrm{P}$ - Proposed monitoring $\mathrm{Rp}$ - report in progress

\section{Monitoring Reports}

Golder Associates Ltd. 1995. Limnology of the Oldman Reservoir and Its Effects on Oldman River Water Quality (1991-1993) - Interim Rept. Prep. for Alberta Environmental Protection. 33 pp. + Tables and Figures.

Mitchell, P. 1998 (draft). Temperature and Dissolved Oxygen in the Oldman River, Summer 1991-1994. Alberta Environmental Protection, Edmonton.

\section{References and Other Selected Reports ${ }^{1}$}

HydroQual Canada Ltd. 1990. Data Summary on Oldman River Water Quality Projections. Prep. for Planning Division, Alberta Environment. 160 pp. + Appendices.

HydroQual Canada Ltd. 1990. Re-evaluation of the Dissolved 0xygen in the Lower Oldman River. Prep. for Planning Division, Alberta Environment. Briefing Note.

Northwest Hydraulic Consultants Ltd. 1987. Oldman River Dam. Preliminary Engineering Report. Appendix C. River morphology and sedimentation. Prep. for Alberta Environment. 24 pp.

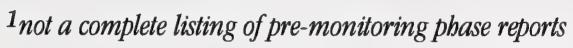


Background

\section{Initial Concerns}

Impoundment and regulation of river flows can cause changes to the distribution, composition and density of benthic invertebrates. Many invertebrate species such as mayflies and stoneflies depend on temperature "cues" for undergoing developmental stages. Changes in water temperature below the dam may cause these cues to disappear or be altered. Prior to impoundment the assemblage of aquatic invertebrates in the Oldman River upstream of Fort Macleod was characteristic of clear, coldwater foothill streams with fast currents, high dissolved oxygen, and cobble-boulder substrate. Immature mayflies and stoneflies predominated, and taxonomic diversity was higher than in the lower reaches (below Fort Macleod). The possibility that these important sportfish food species might disappear below the dam due to changes in water quality was a concern.

\section{Mitigative Action}

Three sites on the Oldman River were part of the Long-term Invertebrate Monitoring Program which monitored for benthic invertebrates in spring and fall on a 5 -year cycle beginning in 1983. Information from these sites was combined with forecasts about the water quality and productivity from computer modelling to predict downstream effects of the dam on the distribution and abundance of aquatic invertebrates. The major predictions were as follows:

\section{Dam to Lethbridge Northern Irrigation District (LNID) diversion}

$L$ overall reduction of density and diversity of benthic invertebrates due to a combination of abrupt changes in flow and temperature regime

$\llcorner$ few, if any mayfly, stonefly and caddisfly species

$\llcorner$ disappearance of upper Oldman River species assemblage

$\llcorner$ possible increase in blackfly larvae

$L$ increased densities of aquatic taxa (oligochaetes, Hydrozoa, gastropods) in summer

\section{LNID diversion to Lethbridge}

$\llcorner$ fluctuating temperatures with negative effects on some taxa

$L$ (downstream from the Belly River confluence): plant growth and benthic invertebrates more abundant

\section{Downstream from Lethbridge}

$L \quad$ increased dissolved oxygen levels from flow regulation, resulting in increased density and diversity of many taxa, including caddisflies and mayflies 


\section{Monitoring}

\section{What Was Done}

To assess the effects of the dam on downstream invertebrates, the river was sampled for invertebrates in the spring and fall of 1992, 1994 and 1997. The sampling sites include the three long-term monitoring sites established in the 1980s (Table 4 and Figure 9).

Table 4

Oldman River Invertebrate Monitoring Program

\begin{tabular}{|c|c|c|c|c|c|c|c|c|}
\hline Site & & & & & ars & & & \\
\hline & $\begin{array}{c}\text { Spring } \\
1984\end{array}$ & $\begin{array}{l}\text { Fall } \\
1984\end{array}$ & $\begin{array}{c}\text { Spring } \\
1992\end{array}$ & $\begin{array}{l}\text { Fall } \\
1992\end{array}$ & $\begin{array}{c}\text { Spring } \\
1994\end{array}$ & $\begin{array}{c}\text { Fall } \\
1994\end{array}$ & $\begin{array}{c}\text { Spring } \\
1997\end{array}$ & $\begin{array}{c}\text { Fall } \\
1997\end{array}$ \\
\hline Waldron's Corner & + & + & + & + & + & + & + & + \\
\hline Brocket & + & + & + & + & + & + & + & + \\
\hline Fort Macleod & + & + & + & + & + & + & + & + \\
\hline Monarch & + & + & + & + & + & + & + & + \\
\hline Lethbridge & + & + & + & + & & & & \\
\hline Highway 845 & + & + & + & + & + & + & + & + \\
\hline Upstream of Taber & + & + & + & + & & & & \\
\hline Hwy 36 & + & + & + & + & + & + & + & + \\
\hline at Mouth & + & + & + & + & & & & \\
\hline
\end{tabular}

+ - samples collected 
0
0
\pm
0
0
0
0
5
0
2
5
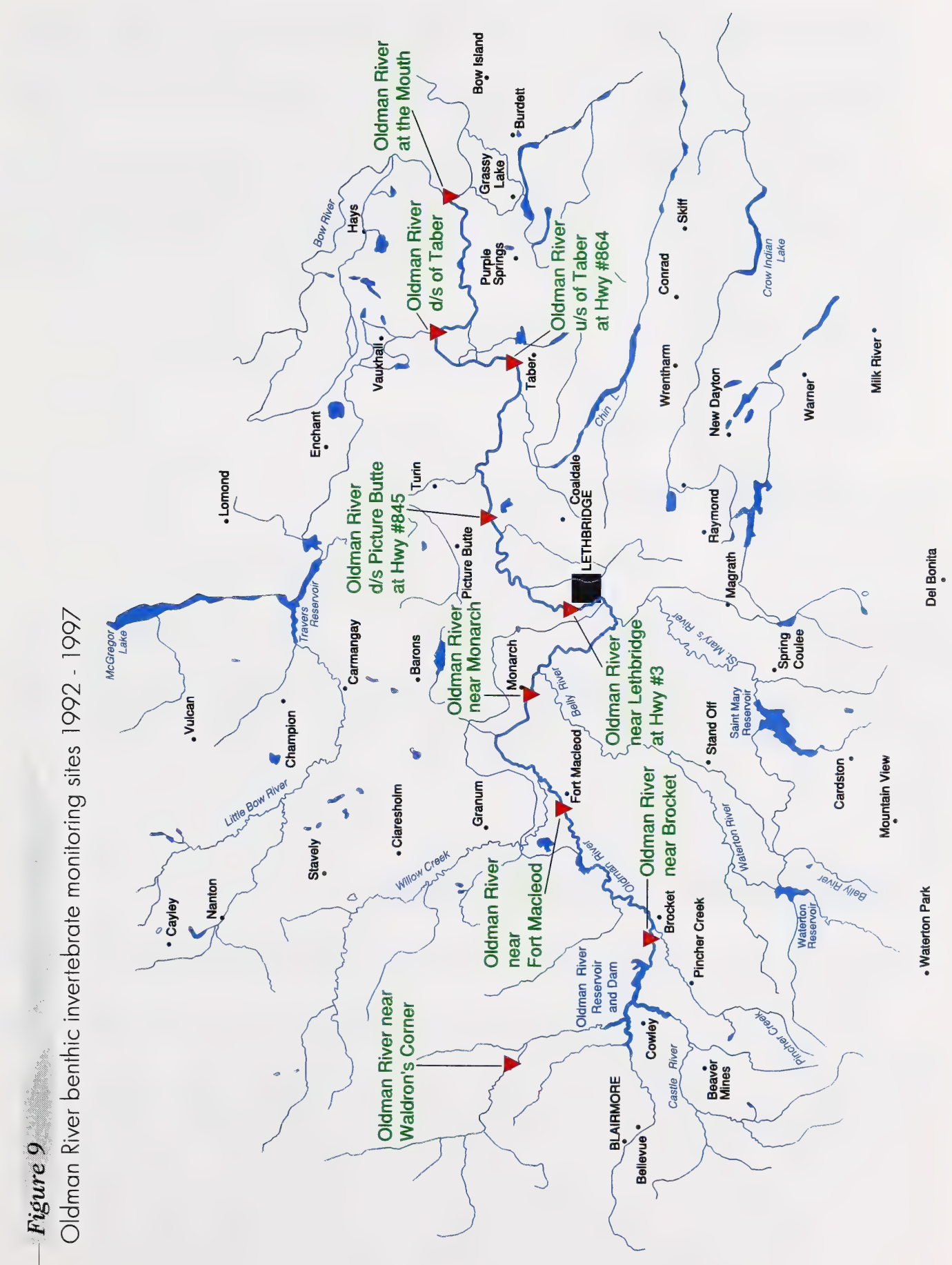


\section{What Was Found}

The results described below were obtained in 1992. As the reservoir was still filling at this time, they may not be representative of later years when streamflow and temperature would be more affected by the reservoir. Analysis of the data collected in subsequent years is currently underway.

The predicted decline in invertebrate numbers and diversity between the dam and LNID diversion had not occurred as of 1992. Instead, an increase in the relative abundance of some benthic invertebrates was found, particularly at the site nearest the dam (Brocket) and to a lesser degree at sites further downstream. Invertebrates of reservoir origin increased at Brocket and blackfly larvae increased in the fall, as predicted. The predicted decline in abundance of mayflies and stoneflies was not seen.

Downstream from Brocket, no impacts attributable to reservoir effects were seen in 1992. Stoneflies declined gradually in number with distance in spring and fall, probably as a result of organic enrichment.

\section{Monitoring Timeline and Budget}

From 1992/93 through 1997/98 the invertebrate monitoring component received $\$ 23,250$.

\begin{tabular}{|l|c|c|c|c|c|c|c|c|}
\hline Sampling Location & $91 / 92$ & $92 / 93$ & $93 / 94$ & $94 / 95$ & $95 / 96$ & $96 / 97$ & $97 / 98$ & $98 / 99$ \\
\hline Downstream of Dam & & $\mathrm{D}$ & & $\mathrm{D}$ & & $\mathrm{D}$ & & $\mathrm{Rp}$ \\
\hline
\end{tabular}
D - data collected Rp - report in progress

\section{Monitoring Reports}

Anderson, W.J. 1993 (draft). Results from the Benthic Invertebrate Survey of the Old Man River, 1992. Data report. Alberta Environmental Protection, Edmonton.

Anderson, W.J. 1997 (draft). Benthic Invertebrate Survey Data from the Old Man River, Spring 1994 and Fall 1994. Data report. Alberta Environmental Protection, Edmonton.

Golder Associates Ltd. 1995. Limnology of the Oldman Reservoir and Its Effects on Oldman River Water Quality (1991-1993) - Interim Rept. Prep. for Alberta Environmental Protection. 33 pp. + Tables and Figures. 


\section{References and Other Selected Reports ${ }^{1}$}

Anderson, A.M. 1989. Predicted Effects of Flow Regulation on the Oldman River Zoobenthos. Environmental Quality Monitoring Branch, Alberta Environment, Edmonton. 27 pp.

Anderson, A.M. 1991. An Overview of Long-Term Zoobenthic Monitoring in Alberta Rivers (1983-1987).

Environmental Quality Monitoring Branch, Alberta Environment, Edmonton. 115 pp.

Cross, P.M. and A.M. Anderson. 1986. Oldman River Dam - Assessment of Downstream Water Quality Effects and Conditions. Water Quality Control Branch, Alberta Environment, Calgary. 137 pp.

$\mathbf{1}_{\text {not a complete listing of pre-monitoring phase reports }}$

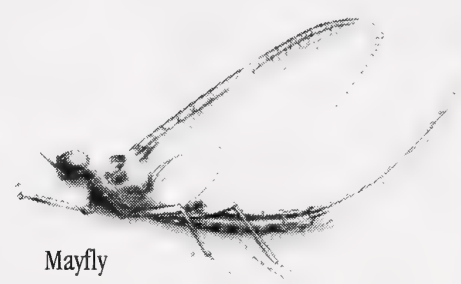




\section{Background}

\section{Initial Concerns}

Inundation of the lower Crowsnest, Castle and Oldman rivers would mean loss of a trout fishery enjoyed by many anglers. Surveys of these river reaches showed that there would be significant loss of some of the highest quality trout habitat in the province, namely, holding habitat for rainbow trout on all three rivers and for brown trout on the Crowsnest River. The dam itself would block the migration of bull and rainbow trout that overwintered downstream and migrated into upstream tributaries to spawn. This was of particular

holding habitat

deep runs or pools providing refuge from currents and predators concern because bull trout populations were declining in Alberta and throughout the species' range.

\section{Mitigative Action}

The Government of Alberta made a commitment that there will be "no net loss of recreational fishing opportunities" as the result of the Oldman River Dam. To achieve this, a fisheries mitigation strategy with two main goals was developed:

1. Enhance trout habitat in river reaches upstream and downstream of the Oldman River Reservoir to replace high quality fish habitat lost due to reservoir filling. The habitat type targeted for replacement was high quality holding or resting habitat (runs and pools). It was replaced by upgrading fisheries habitat of a lower quality through the installation of instream features such as rock weirs, flow deflectors, groynes, boulder gardens, and overhanging cover. The target amount of

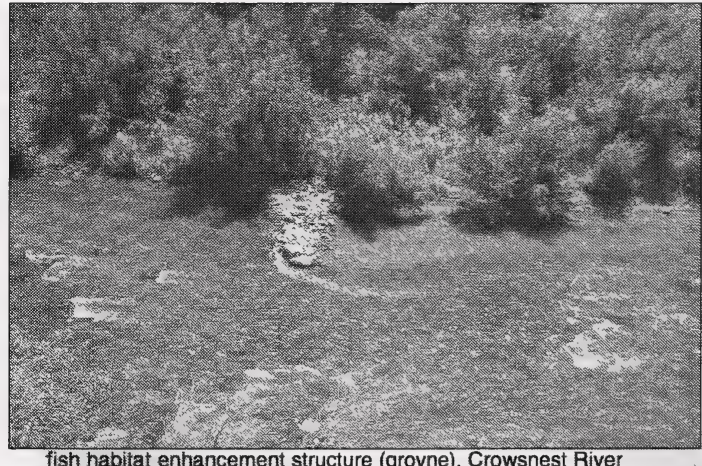

fish habitat enhancement structure (groyne), Crowsnest River riverine habitat to be replaced was $225,000 \mathrm{~m}^{2}$, which was equivalent to the total amount of highest quality and moderately high quality habitat lost. Upstream habitat enhancement projects were implemented on the Crowsnest, Castle and north fork 0ldman rivers and on Todd Creek. Downstream of the dam, lack of instream cover was thought to be the major limiting factor for trout production. Large boulders were added to existing deep runs and pools to produce high quality holding habitat.

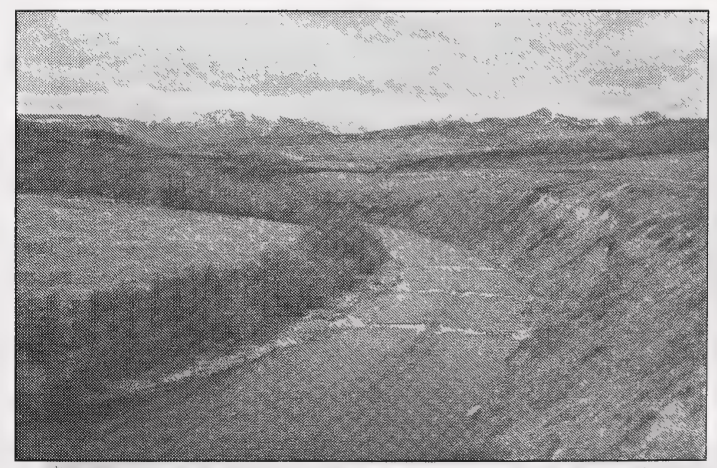

fish habitat enhancement structures (V-weirs), Crowsnest River) 
2. Develop a self-sustaining (naturally reproducing) trout fishery in the Oldman River downstream of the reservoir to compensate for the blockage of fish movements at the dam. Prior to construction of the dam, water temperatures were unsuitable for trout spawning and egg incubation. However, flow regulation was expected to improve these conditions by eliminating extreme low flows. Trout as well as cool-water sportish in the river such as walleye, sauger, northern pike, lake whitefish, sturgeon and goldeye were expected to benefit from this.

Based on assessments of fish habitat and water quality and following public consultation, it was decided that the river would be managed for brown and rainbow trout from the dam downstream to Rocky Coulee. In the cool water zone, which was expected to extend from Rocky Coulee to the confluence with the Little Bow River, the river would be managed for brown trout, walleye and sauger. It was assumed that conditions for brown trout would also be suitable for mountain whitefish.

The flow volumes that would provide suitable temperatures and dissolved oxygen for all life stages of the species to be managed were calculated, as shown in Figure 10. These were then used in developing monthly operating guidelines for the reservoir (see Operations section).

\section{habitat units}

To calculate the habitat equivalencies of different river reaches, a standardized habitat unit was adopted. This allowed various river reaches to be "mixed and matched" when comparing habitat losses and gains. The standard unit is based on the lower Crowsnest River, a highly productive reach. In terms of these units, the amount of habitat targeted for replacement was $98,365 \mathrm{~m}^{2}$ of high quality and 9,865 $\mathrm{m}^{2}$ of moderately high quality habitat.

\section{Figure 10}

Estimation of habitat flow requirements: brown trout in the Oldman River Reservoir April - October, 1994

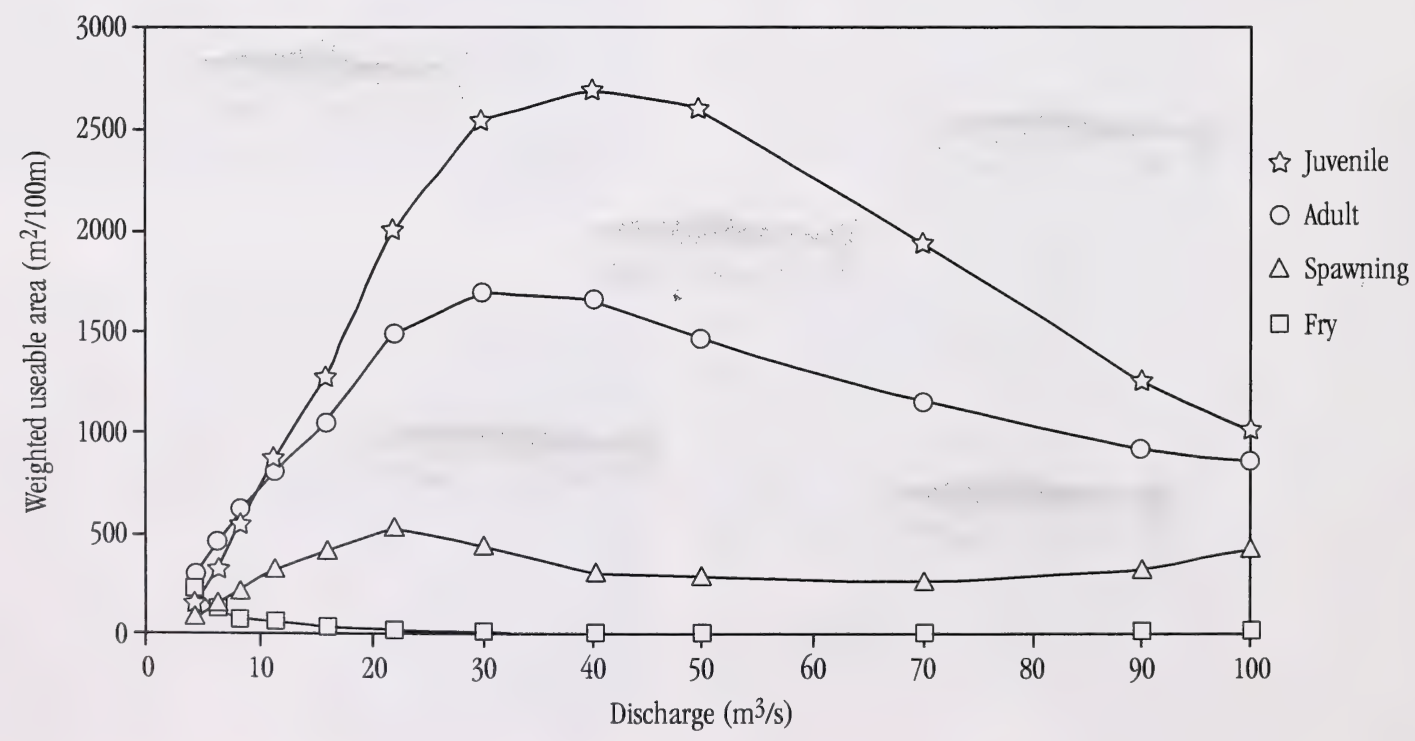


Water temperatures below the dam were expected to be unsuitable for spawning of rainbow trout in most years but suitable for spawning of brown trout. Approximately 700,000 brown trout fingerlings were stocked between Fort Macleod and Monarch between 1992 and 1997.

Other mitigative measures taken include the transport of sportfish around the dam from 1989 through 1992 and the transplant of bull trout into Pincher Creek in 1996 and 1997 in an attempt to establish a population that would spawn in a tributary of the Oldman River downstream of the dam. In the transport program, 161 bull trout, 1,995 rainbow trout, and 8,512 mountain whitefish were captured below the dam and released several kilometres upstream.

The public consultation process had given highest mitigation priority to river reaches upstream of the reservoir, followed by downstream reaches. The reservoir itself was placed third in priority because of predictions that reservoir conditions would not be productive for sportfish year-round. The unfavourable conditions expected included lack of nutrients, low temperatures, high flushing rates and a poorly vegetated littoral zone due to water level fluctuations. However, the reservoir was expected to serve as an overwintering area for rainbow trout, bull trout and mountain whitefish. An abundance of coarse fish species such as suckers was also expected.

Mitigation Evaluations: The Fisheries Mitigation Program has been the responsibility of Alberta Public Works, Supply and Services. The Alberta Government made a commitment to evaluate the effectiveness of the habitat enhancement techniques from both a fisheries and engineering perspective over a ten-year implementation period. A regular program of structure evaluations has been conducted since 1987. This program also monitors the integrity of individual structures. The data collected will be used to determine operation and maintenance procedures and schedules.
By 1994, habitat enhancement on the Crowsnest, Castle and north fork Oldman rivers as well as downstream of the reservoir was completed. In 1995, the largest flood ever recorded in the 0ldman River Basin damaged about $44 \%$ of the enhanced habitat and left unstable channels in the Castle and north fork 0ldman rivers. Enhancement works in the Crowsnest River suffered relatively minor damage and were repaired in 1996-97. Replacement work for the Castle and Oldman rivers had to be done mainly on the Oldman River downstream of the dam. By 1998 the target amount of habitat works had been met and surpassed.

Evaluation of the response of fish populations to the mitigation work has been complicated by several factors including the 1995 flood, changes in fishing regulations on the Crowsnest River in 1992 and 1995, and a decrease in nutrient inputs to the upper Crowsnest River due to upgrading of a sewage treatment plant in 1988. However, the following generalizations can be made:

$\llcorner$ Enhanced sites generally attracted trout in similar numbers to nearby natural (control) high quality sites.

$\llcorner$ Although it is too soon to conclude whether a stable population of brown trout has developed downstream of the dam, signs are encouraging. In 1997, one of the first years in which the stocked fish would have been mature enough to spawn, brown trout redds were found in the vicinity of Fort Macleod.

$L$ No spawning sites associated with the transplanted bull trout have been found in Pincher Creek. 


\section{Monitoring}

The Fisheries Monitoring Program was designed to determine:

$\llcorner$ whether the Oldman River Dam has been detrimental to the sportfish populations that were present in the river system before impoundment;

$\llcorner$ the extent to which various fish species use the reservoir;

$L$ whether predictions of benefit to cool-water species downstream of the dam were correct;

$L$ whether post-impoundment levels of sportfishing opportunities are the same as pre-impoundment levels.

This information is required not only for fish management purposes but also as a condition of the Navigable Waters Protection Act approval and authorization by Fisheries and Oceans Canada (Appendices D and E).

\section{What Was Done}

Radio telemetry surveys of trout movements and habitat use: Radiotelemetry was used to determine how the seasonal movements, habitat use and spawning of rainbow and bull trout were affected by the reservoir. From 1993 through 1996, bull and rainbow trout were implanted with radio transmitters in spring and relocated by aerial survey throughout the rest of the year. Various capture and release sites were used so that an overall picture of trout movements could be obtained. A total of 75 bull trout and 23 rainbow trout were radio-tagged during the course of this study.

Bull trout redd surveys (upstream): Ground-based surveys of redds were carried out after the fall spawning season in 1996 at sites where radio-tagged bull trout had been located in late summer and fall. Redd surveys were also carried out by Alberta Environmental Protection in headwater streams of the Oldman River Basin from 1995-1997.

Fish population studies: The fisheries mitigation studies described above have provided useful information about riverine fish populations. Data were also obtained on species composition, age distribution, growth rates, and diet composition of fish in the reservoir during the sampling of fish for mercury each fall from 1991 through 1995. Future fisheries studies will be conducted through the monitoring program, with the exception of those mitigation studies already underway.

Creel surveys: Creel surveys were conducted at the reservoir in 1994 and downstream in the Oldman River in 1996 and 1997 to determine catch rates and angler satisfaction. Alberta Environmental Protection conducted creel surveys on the Crowsnest River in 1990 and 1994. 


\section{What Was Found}

Fish distribution and movement upstream of the Dam

Bull Trout: The radiotelemetry studies indicate that most bull trout overwinter in the reservoir. A large percentage of the juvenile trout and small percentage of the adults appear to reside in the reservoir year-round. During the spring and summer most adult bull trout move into the tributary streams, primarily the Castle River and, to a lesser extent, the north fork Oldman and Crowsnest rivers (Figure 11). In early fall further movement upstream takes place in preparation for spawning. Evidence from radiotracking suggests that adults do not spawn every year.

\section{Figure 11}

Example of bull trout movement (from Golder Associates Ltd. 1996c)

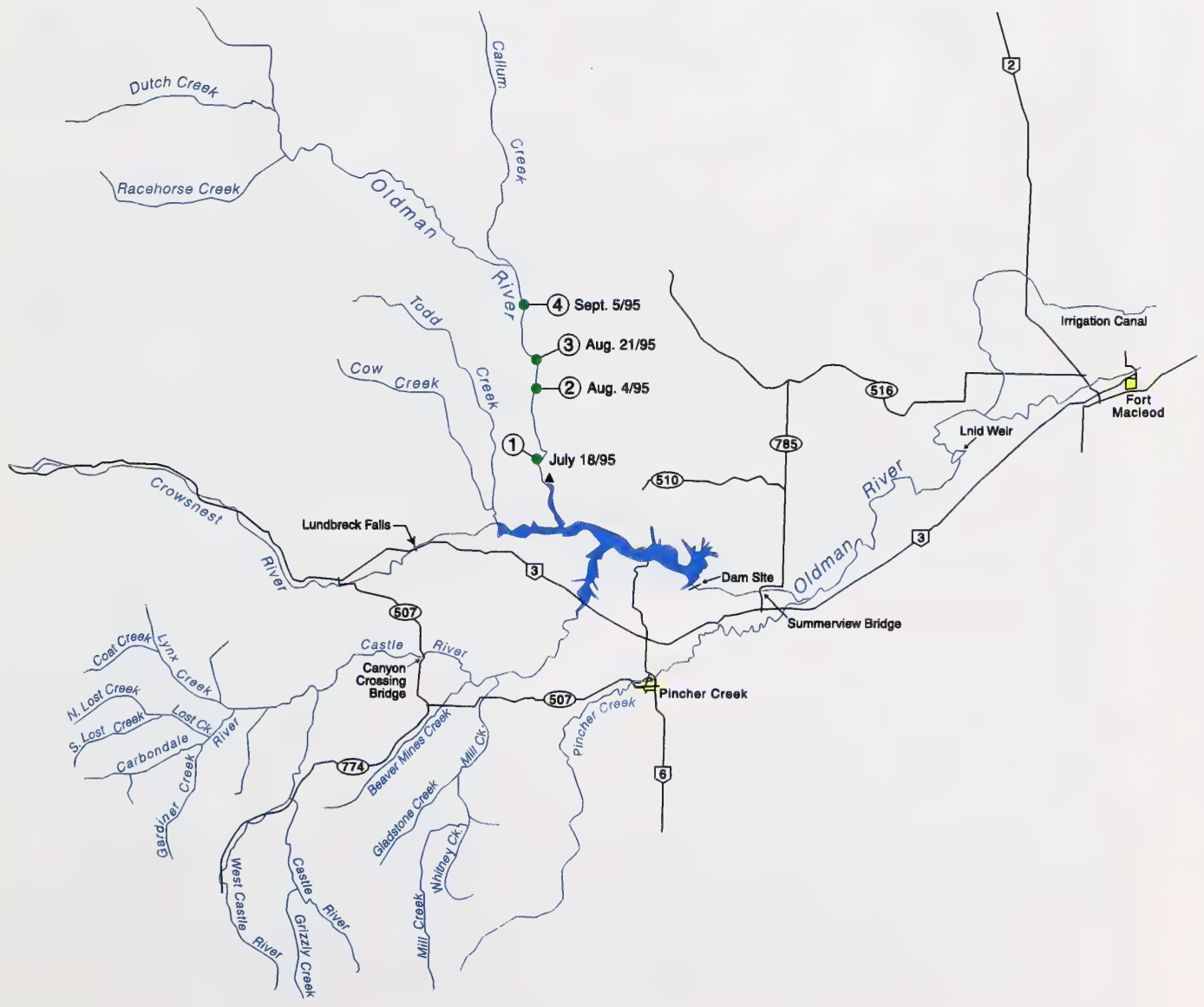


Bull trout redds were found in the Crowsnest River a short distance from the reservoir in 1996. It is not known whether this is a traditional or new spawning site.

Three of 11 bull trout released upstream of the dam were found downstream in 1993.

Movement over the dam was not found in the other years.

Rainbow trout: Radio-tagged rainbow trout tended to remain in the reservoir longer than did bull trout, using it for feeding, rearing and overwintering. The months of highest angler catch rates per unit effort were April and October while the lowest were May and August. This suggests that the trout remain in the reservoir until May, travel upstream to spawn, and then migrate downstream to the reservoir again in the fall. Most of the fish caught by anglers were 3-4 years of age. A similar age category predominated in the gill-net samples obtained in the fall.

Reservoir fish productivity: The three major sportfish species present in the Oldman River system before impoundment (mountain whitefish, rainbow trout and bull trout) are relatively abundant in the reservoir, as are longnose and white suckers. Brown trout are present in smaller numbers, while lake trout and cutthroat trout are fairly scarce.

Fish populations in the Oldman River Reservoir were assessed from data collected during the sampling of fish for mercury analysis during midSeptember to midOctober from 1991 through 1995. Fish abundance appears to be relatively high compared to that reported for other coldwater reservoirs. Overall gill-net catch rates were higher than those at Glennifer Lake (Dickson Dam) during its initial years of operation. Likewise, angler catch rates for rainbow trout exceeded those at Glennifer Lake and a similar coldwater reservoir in Wyoming. Over 6000 rainbow trout were harvested from the reservoir between April and November 1994 as estimated by creel survey. No significant changes occurred in gill-net catch rates for various species over the five years of sampling, with the exception of longnose sucker, which first declined (in 1991 to 1993) and then increased to preproject levels in 1994 and 1995.

Bull trout in the reservoir feed mainly on fish while rainbow trout and mountain whitefish feed mainly on zooplankton Daphnia spp. Rainbow trout in the reservoir were found to have higher growth rates than rainbow trout upstream and downstream of the reservoir, where Daphnia comprises less of the diet. On the other hand, mountain whitefish in the reservoir were found to be growing and attaining maturity more slowly than those in the river. This may reflect a scarcity of benthic invertebrates, their usual food source, in the reservoir.

Downstream fisheries: Rainbow trout are now abundant in the tailwater area immediately below the dam, and rainbow trout redds were found in this vicinity in 1995 . The results of brown trout stocking are described in Mitigation Evaluations above.

Angling opportunity: Part of the evaluation of whether the commitment to "no net loss of recreational fishing opportunities" has been met involves examining catch rates and angler satisfaction with fishing conditions. Results of creel surveys conducted to date are summarized briefly below.

$\llcorner$ Crowsnest River, 1990: The majority of anglers found the habitat enhancement structures aesthetically acceptable and felt that catch rates for trout were satisfactory.

$\llcorner$ Crowsnest River, 1994 (following institution of more restrictive regulation changes on the lower Crowsnest River in 1992): Angling success was greater than in 1986, despite increased angling pressure. Catches of rainbow trout had doubled and catch rates increased by more than $50 \%$. In 1994 approximately $75 \%$ of anglers used flies and $98 \%$ of anglers released their catches.

$\llcorner$ Reservoir, January through March 1994: Angler satisfaction with size of fish and overall fishing experience started at a high of over $50 \%$ and declined over the course of the ice-fishing season. Satisfaction with number of fish caught was low. 
$\llcorner$ Reservoir, April to October 1994: Approximately $70 \%$ of anglers interviewed were satisfied with their overall fishing experience. Less than half were satisfied with the size or number of fish caught except during the fall, when this increased to $60 \%$. The mean monthly catch rates for rainbow trout during this period are shown in Figure 12.

L Downstream of the Oldman River Dam midjuly to midAugust 1996: Of eleven sites surveyed, the most popular were those immediately downstream of the dam. Rainbow trout was the most abundant species caught within the PRA, while brown trout was the most abundant species downstream of the Peigan Reserve. The mean catch rate (all sites) was 0.8 fish per angler hour.

\section{Figure 12}

Mean monthly catch rates for rainbow trout in the Oldman River Reservoir, April - October, 1994 (from Ripley 1995a)

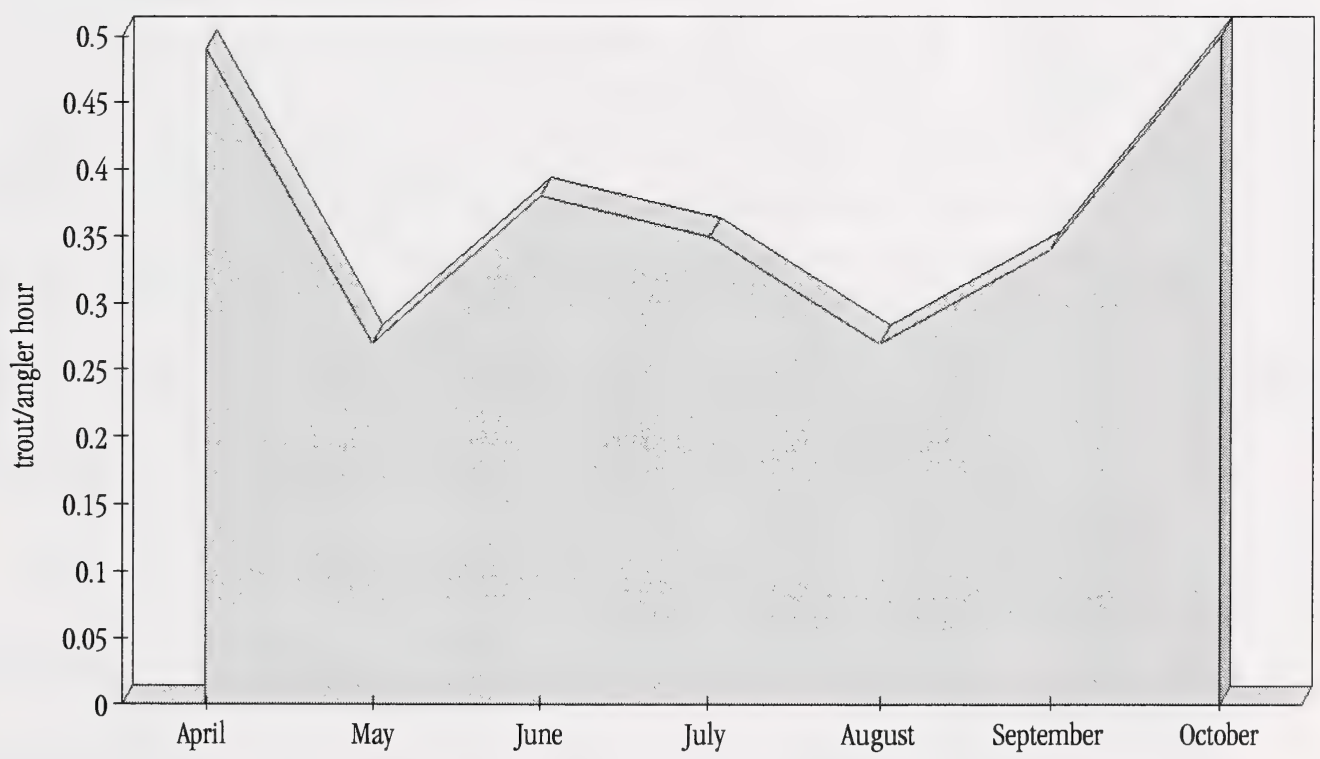




\section{Monitoring Timeline and Budget}

From 1992/93 through $1997 / 98$ the fisheries component received a total of $\$ 306,250$.

\begin{tabular}{|l|c|c|c|c|c|c|c|c|}
\hline & $91 / 92$ & $92 / 93$ & $93 / 94$ & $94 / 95$ & $95 / 96$ & $96 / 97$ & $97 / 98$ & $98 / 99$ \\
\hline Trout Telemetry & & & $\mathrm{D} / \mathrm{R}$ & $\mathrm{D} / \mathrm{R}$ & $\mathrm{D} / \mathrm{R}$ & $\mathrm{D} / \mathrm{R}$ & & \\
\hline Reservoir fish & $\mathrm{D} / \mathrm{R}$ & $\mathrm{D} / \mathrm{R}$ & $\mathrm{D} / \mathrm{R}$ & $\mathrm{D} / \mathrm{R}$ & $\mathrm{D} / \mathrm{R}$ & & & \\
\hline $\begin{array}{l}\text { Downstream Creel } \\
\text { Survey }\end{array}$ & & & & & & $\mathrm{D} / \mathrm{R}$ & $\mathrm{D} / \mathrm{Rp}$ & $\mathrm{P}$ \\
\hline
\end{tabular}

D - data collected $\quad \mathrm{R}$ - report completed $\mathrm{P}$ - Proposed monitoring $\mathrm{Rp}$ - report in progress

\section{Monitoring Reports}

Carlson, L. and M.Quinn. 1998. The Oldman River Dam Fisheries Mitigation Program - Annotated Bibliography of Completed Fisheries Reports. Prep. for Alberta Environmental Protection. 18 pp.

Golder Associates Ltd. 1998 (draft). The Oldman River Bull Trout Radio Telemetry Study, 1993-1996. Prep. for Alberta Environmental Protection, Lethbridge. $31 \mathrm{pp}$.

Golder Associates Ltd. 1996a. The 1993 0ldman River Bull Trout and Rainbow Trout Radio Telemetry Study. Prep. for Alberta Environmental Protection. 29 pp.+ App.

Golder Associates Ltd. 1996b. The Oldman River Bull Trout and Rainbow Trout Radio Telemetry Study, 1994. Prep. for Alberta Environmental Protection, Edmonton. 27 pp.+ App.

Golder Associates Ltd. 1996c. The Oldman River Bull Trout Radio Telemetry Study, 1995. Prep. for Alberta Environmental Protection, Edmonton. 21 pp. + App.

Meller, B.D. 1995. Assessment of the Hydraulic Regime of Fish Habitat Enhancement Structures - Castle River at Rodeo Grounds. 23 pp. + App.

Ripley, T. 1995a. Oldman Reservoir Summer Creel Survey, 1994. Alberta Environmental Protection, Lethbridge. 67 pp. Ripley, T. 1995b. Oldman Reservoir Winter Creel Survey January-March, 1994. Alberta Environmental Protection, Lethbridge. $44 \mathrm{pp}$.

Wainman, J. 1997. Downstream Creel Census - Oldman River Dam Provincial Recreation Area. Prep. for Alberta Environmental Protection. $33 \mathrm{pp}$. 


\section{References and Other Selected Reports ${ }^{1}$}

Council, T. 1995. Crowsnest River Angler Survey 1994. Alberta Environment, Fish and Wildlife Service, Lethbridge. $62 \mathrm{pp}$.

Dominion Ecological Consulting Ltd. and J N Mackenzie Engineering Ltd. 1988. A Strategy for Fisheries Mitigation in the Oldman River Basin. Vol I. Upstream Component. Prep. for Alberta Environment and Alberta Forestry, Lands and Wildlife, Edmonton. 95 pp. + App.

Dominion Ecological Consulting Ltd. 1990. A Strategy for Fisheries Mitigation in the Oldman River Basin. Vol II. Downstream and Reservoir Components. Prep. for Alberta Public Works, Supply and Services, Edmonton. 178 pp + App.

Golder Associates Ltd. 1995. Fish Habitat Suitability in the Oldman River Based on Water Temperature and Species Life Stage Requirements. Prep. for Alberta Environmental Protection.

Golder Associates Ltd. 1998. Bull Trout (Salvelinus confluentus) Transfer from the Lower Oldman River and Pincher Creek Redd Surveys (1996 and 1997).

0'Callaghan, D. and J.H. Allan. 1994. Assessment of Potential Angler Access to Reaches 8 and 9 of the Lower Oldman River. Pisces Environmental Consulting Services Ltd.

R.L.and L. Environmental Services Ltd. Annual Reports (1989-97), Fisheries Evaluation Program.

R.L.and L. Environmental Services Ltd. 1992. Angler Creel and Opinion Survey. Crowsnest River, 1990.

R.L.and L. Environmental Services Ltd. 1993. Fish Population Responses in Crowsnest River to OMRD Mitigation Program, 1987-1991.

Schwalme, K. and K. Smiley. 1997. A Five-year Post-impoundment Study of Fish Biology in Alberta's Oldman River Reservoir and Adjoining Streams. Alberta Research Council, Vegreville. 65 pp.

$1_{\text {not a complete listing of pre-monitoring phase reports }}$

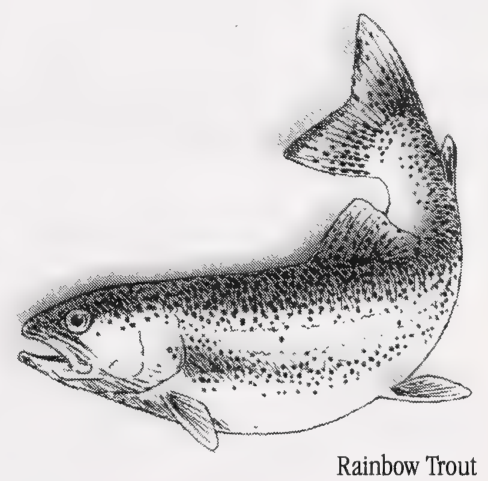




\section{Background}

\section{Initial Concerns}

When a reservoir is filled, inorganic mercury in the soil and vegetation is converted by bacteria to methyl mercury. This form of mercury is taken up by plants, zooplankton, and benthic invertebrates and passed along to fish and fisheating animals. It is deposited in the muscle tissue of fish where it accumulates, being only slowly metabolized. Methyl mercury is damaging to the human nervous system. Health and Welfare Canada has prescribed a guideline of 0.5 milligrams of total mercury per kilogram of consumable fish to protect human health. If concentrations of mercury in fish exceed this level, the public is warned and consumption of the fish is generally restricted.

\section{the methylation process}

Many kinds of bacteria and other microorganisms in the soil are capable of methylating inorganic mercury. The methylation process can occur under both aerobic (oxygen-containing) and anaerobic conditions. It can also take place as an abiotic chemical transformation under certain conditions. The rate of methylation depends on the amount of mercury available and on many factors affecting bacterial activity. Oligotrophic reservoirs often have relatively high available mercury; however, bacterial processes in such reservoirs may be slow. Methyl mercury does not readily decompose but can be degraded by some microorganisms in aquatic environments. Thus the rate of methyl mercury formation in a waterbody is the net balance between methyl mercury production and degradation.

\section{Mitigative Action}

Two steps were taken to reduce the potential of increasing mercury concentrations in fish due to the construction of the Oldman River Dam. Both of these steps consisted of removing mercury from the reservoir before it could enter the food chain:

L Approximately 440 hectares of trees and shrubs, including all plants more than three metres tall, were cleared from the area to be flooded. This eliminated the mercury that would have been released as the wood decomposed in the reservoir.

$\llcorner$ Most of the high quality topsoil (ca. 150,000 cubic meters) was salvaged from the area to be flooded. 


\section{Monitoring}

The monitoring program for mercury in fish is designed to assess changes in the mercury content of fish muscle tissue that may have resulted from the 0ldman River Reservoir. This research represents the most extensive reservoir-fish mercury study ever conducted in Alberta. Monitoring of mercury levels in fish was one of the conditions imposed by Fisheries and Oceans Canada in its authorization of the Oldman River Dam.

\section{What Was Done}

Fish were sampled in the reservoir, upstream and downstream each fall from 1991 through 1995 and also in 1997. Fish collected at a site upstream of Lundbreck Falls on the Crowsnest River served as controls, as the falls are a barrier to upstream movement by fish. An additional upstream site on the north fork of the Oldman River also was sampled during the 1991 to 1994 study period. Fish were also collected in the main part of the reservoir, immediately downstream of the reservoir, and near Fort Macleod. In order to obtain more data from the reservoir in 1995 and 1997, additional sites within the reservoir were sampled. The north fork Oldman and Fort Macleod sites were not sampled in 1997.

The main species sampled were mountain whitefish, rainbow trout, bull trout, longnose sucker, and white sucker. Muscle tissues were extracted and analyzed for total mercury concentration. Data from all six years of sampling were then combined and analyzed

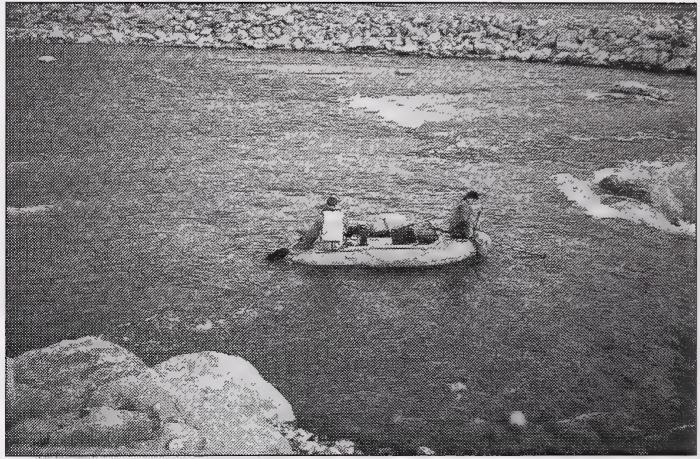

Obtaining fish for mercury sampling

\section{relationship of total mercury to methyl mercury concentration}

Human consumption guidelines are based on methyl mercury concentrations. It is believed that over $90 \%$ of total mercury in fish tissue is in the form of methyl mercury. for trends.

\section{What Was Found}

Mercury levels in fish from the control site were below $0.5 \mathrm{mg} / \mathrm{kg}$ and showed no trend over the course of the study. At the downstream site no trend was apparent in some species, such as white sucker, while a small but significant decrease in mercury was found in other species, such as rainbow trout and mountain whitefish. Within the reservoir small but statistically significant increases in mercury levels were seen in all species from 1991 to 1995. In 1997, mercury levels in fish from the reservoir were lower, suggesting that mercury concentrations may have reached a plateau and begun to stabilize (Figure 13). 


\section{Fiğure 13}

Adjusted mean total mercury concentrations in muscle of bull trout from the Oldman River Reservoir, 1991 - 1997 (from Wu et al. 1998)

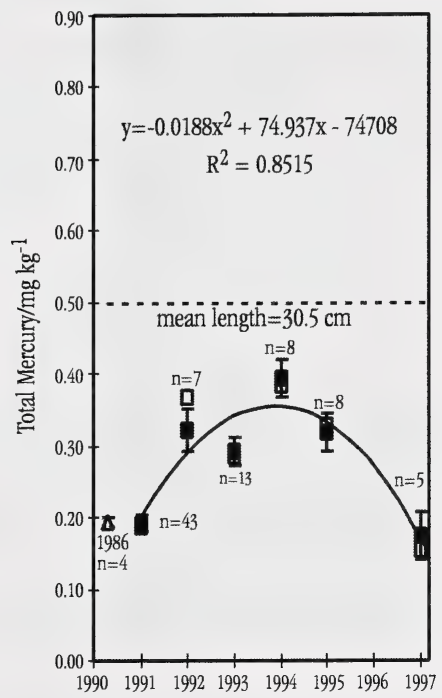

Over the course of the entire study a total of 22 out of 1,484 fish sampled (including controls; $1.3 \%$ ) exceeded the $0.5 \mathrm{mg} / \mathrm{kg}$ guideline for consumption. Yearly mean mercury levels did not exceed the Canadian guidelines for safe human consumption in any species, with the exception of two species for which only a single specimen was obtained (lake trout and burbot).

The highest mercury concentration encountered in the study was $0.869 \mathrm{mg} / \mathrm{kg}$. This was found in a large bull trout taken downstream of the reservoir in 1997. The piscivorous nature of this species and the size of the individual suggests that it accumulated mercury through the consumption of numerous fish. It is conceivable that some of these fish came from the reservoir via the spillway.
The dotted lines represent the $0.5 \mathrm{mg} / \mathrm{kg}$ guideline level. The solid curve represents a significant (at 95\% confidence level) trend. Adjusted mean ( $\square$ ). The arithmetic mean THg concentrations in 1991-1997 ( $\square$ ) and in 1986 $(\triangle)$ are plotted for reference. piscivorous

\section{fish-eating}

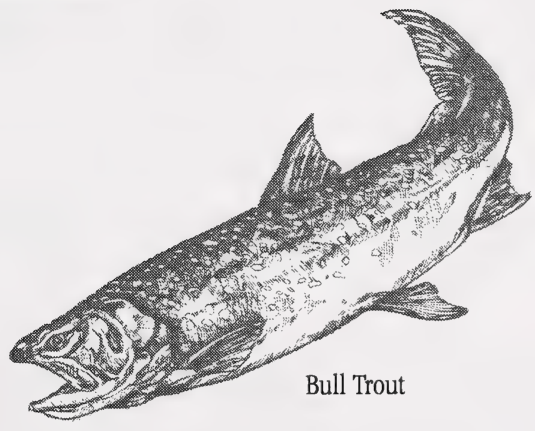




\section{Monitoring Timeline and Budget}

From 1992/93 through 1997/98 this monitoring program component received $\$ 104,500$. Monitoring is planned to continue through 2001 (10 years).

\begin{tabular}{|l|c|c|c|c|c|c|c|}
\hline $91 / 92$ & $92 / 93$ & $93 / 94$ & $94 / 95$ & $95 / 96$ & $96 / 97$ & $97 / 98$ & $98 / 99$ \\
\hline $\mathrm{D} / \mathrm{R}$ & $\mathrm{D} / \mathrm{R}$ & $\mathrm{D} / \mathrm{R}$ & $\mathrm{D} / \mathrm{R}$ & $\mathrm{D} / \mathrm{R}$ & & $\mathrm{D} / \mathrm{R}$ & \\
\hline
\end{tabular}

D - data collected $\quad R$ - report completed

\section{Monitoring Reports}

Moore, J.W., S. Wu, L.Z. Florence. 1993. Oldman River Dam: Mercury in Fish - Interim Report 1991. Alberta Environmental Centre. AECV93-R7. Vegreville. $68 \mathrm{pp}$.

Moore, J.W., S. Wu, L.Z. Florence. 1994. Oldman River Dam: Mercury in Fish - Interim Report 1992. Alberta Environmental Centre. AECV94-R1. Vegreville. 14 pp.

Wu, S., D. Lucyk and H. Adams. 1993. Oldman River Dam Project: 1992 Mercury in Fish Analytical Report. Alberta Environmental Centre, Vegreville. $17 \mathrm{pp}$.

Wu, S., L.Z. Florence, K.L. Smiley and J.W. Moore. 1994. Oldman River Dam: Mercury in Fish Interim Report 1993. Alberta Environmental Centre. AECV94-R9. Vegreville. 13 pp.

Wu, S., Y. Zhao and D.S. Lucyk. 1994. Oldman River Dam Project: 1993 Mercury in Fish Analytical Report. Alberta Environmental Centre, Vegreville. $10 \mathrm{pp}$.

Wu, S., L.Z. Florence, H.V. Nguyen, K.L. Smiley and K. Schwalme. 1996. Oldman River Dam: Mercury in Fish Interim report 1994. Alberta Environmental Centre. AECV96-R3. Vegreville. 22 pp.

Wu, S., L.Z. Florence, H.V. Nguyen, and K.L. Smiley. 1997. Oldman River Dam: Mercury in Fish - Final Report 19911995. Alberta Research Council, Vegreville. 47 pp.

Wu, S., L.Z. Florence, H.V. Nguyen, K.L. Smiley and A. Wharmby. 1998. Oldman River Dam: Mercury in Fish, 1997. Alberta Research Council, Vegreville. 43 pp.

\section{References}

Beijer, K and A. Jernelov. 1979. Methylation of mercury in aquatic environments. Pp. 203-209 in: Nriagu, J.0., ed. The Biogeochemistry of Mercury in the Environment. Elsevier/North-Holland Biomedical Press, N.Y. 


\section{Background}

\section{Initial Concerns}

The Oldman River Valley and its tributary valleys support a variety of vegetation communities - cottonwood and Douglas fir forests, aspen-dominated shrublands, native grasslands and wetlands. Most wildlife species that inhabit this semi-arid region use these riparian habitats for food, water and shelter. The Oldman River Reservoir eliminated approximately $2000 \mathrm{ha}$ of these habitats, thus affecting many wildlife species. The major impacts on wildlife were expected to be:

$\llcorner$ Several hundred mule deer that inhabited the vicinity of the proposed reservoir would be displaced. The reservoir was expected to usurp their fawning and wintering habitat and block their traditional movement patterns.

$\llcorner$ A significant concentration of prairie falcons and other raptors that nested along the river valley cliffs in the vicinity of the proposed reservoir would lose their nesting sites and would probably abandon the area. With only 235 pairs of prairie falcons province-wide, this represented a significant loss.

$\llcorner$ Songbird numbers would decline, as the river valley forest was inhabited by many species that are sensitive to habitat change.

$\llcorner$ Waterfowl would be attracted to the reservoir; however, riparian waterfowl nesting sites would be inundated.

$\llcorner$ Two colonies of yellow-bellied marmots would lose their territories within the reservoir area.

raptor

bird of prey

\section{Mitigative Action}

The Wildlife Habitat Mitigation program began in 1987. Its objectives were to minimize the potential negative impacts of the Oldman River Dam on wildlife and to take advantage of mitigation opportunities arising from the development of the dam and reservoir. This was to be achieved through habitat protection, habitat enhancement and the creation of new habitat.

Wildlife habitat mitigation was defined as compensation for losses of wildlife habitat through the provision of alternate cover habitat and/or cover/food habitat. Mule deer habitat was used as the basis of calculating habitat gains and losses, as mule deer were the most abundant of the large mammals that used the river valley area and had been studied more intensively than other species present. A computer habitat modelling program was used in which vegetation, aspect and land form were assumed to be important variables influencing the distribution of mule deer. Vegetation surveys for this purpose were conducted throughout the development phase of the program.

A wildlife habitat mitigation land base of approximately 2800 ha was acquired and established as a Provincial Recreation Area (Figure 2). This winding, continuous strip of land surrounding the reservoir contains coulees and hills covered with the same grassland, forest and shrub communities that were present in the reservoir area (Figure 14). Many projects were undertaken within the Provincial Recreation Area to protect and enhance natural habitat and increase habitat types that were in short supply in the vicinity. These projects included planning of reservoir clearing so as to protect existing tree and shrub areas that would not be inundated; placement of fences for grazing control, reseeding, planting of tree and shrub seedlings for habitat, installation of snow fences to retain soil moisture, and construction of wetlands. 


\section{Figure 14}

Habitat types before and after construction of the Oldman River Reservoir (adapted from Hornbeck 1998).

pre-development landbase (5239 ha)

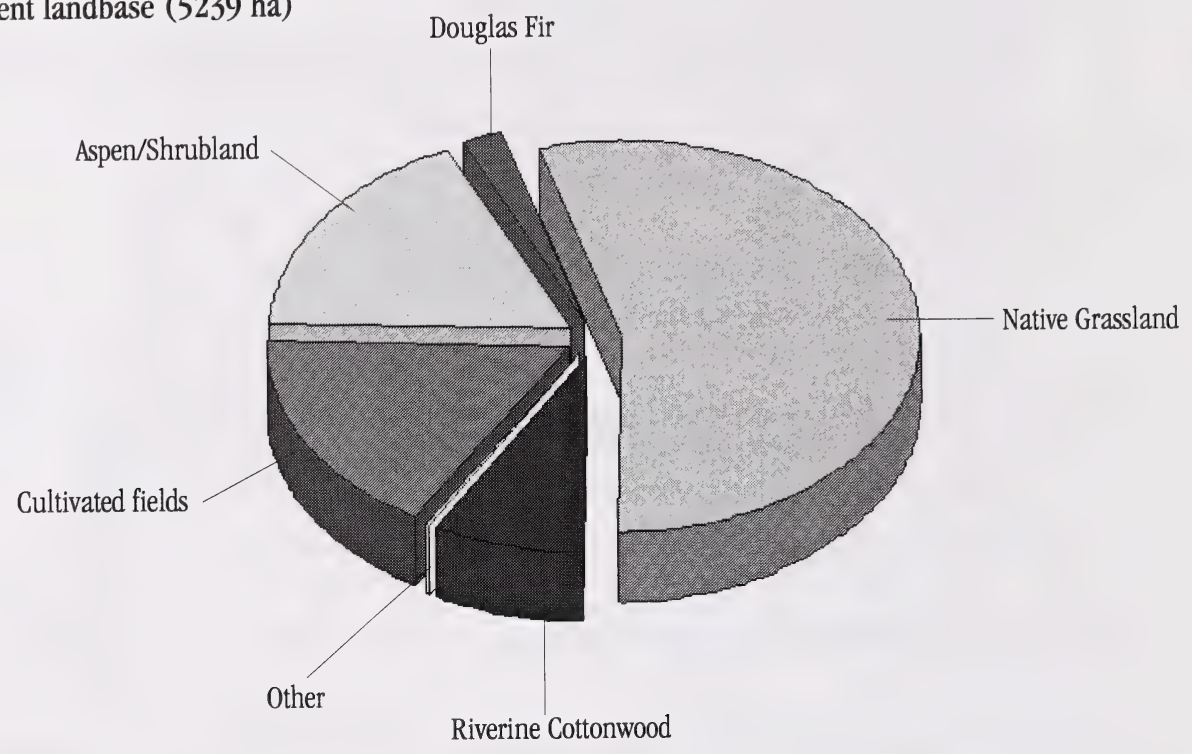

post-development landbase, incl. reservoir (5239 ha)

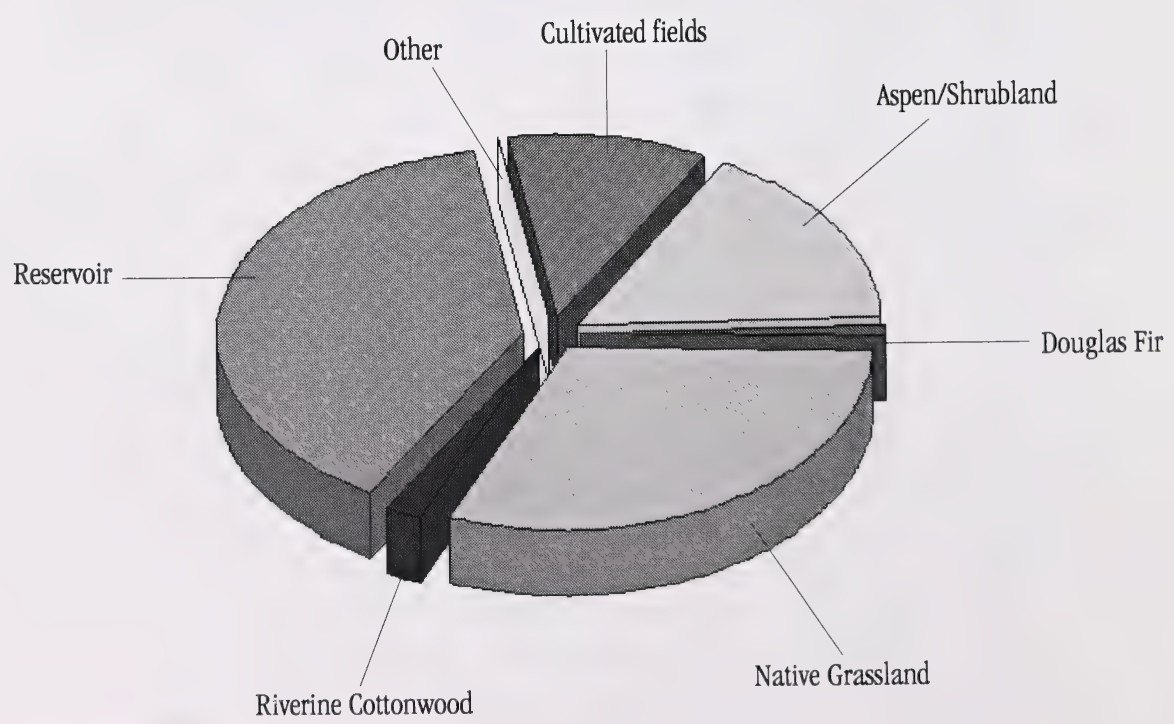




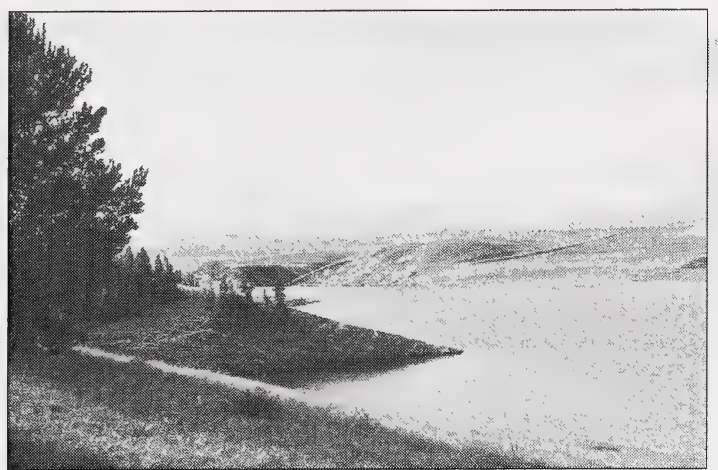

Conifer and grassland habitats within the Oldman River Provincial Recreation Area

The habitat projects were distributed in all areas around the reservoir and travel corridors for wildlife were provided between core habitat areas. Through development of grazing management plans (see Vegetation Section), habitat projects were designed to be compatible with existing agricultural uses.

Habitat needs of species not associated with forest, shrublands, or grasslands were addressed in site-

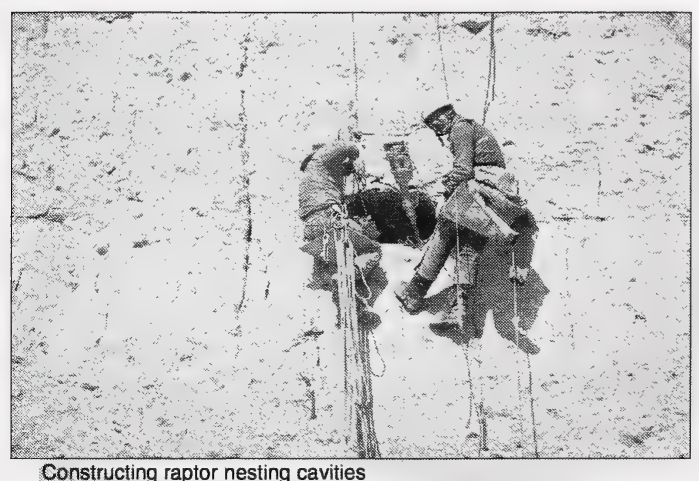
specific ways. To maintain the presence of prairie falcons in the area, cliff nesting sites that would be inundated were replaced with newly excavated nesting cavities or ledges nearby. Between 1989 and 1993, 51 nesting cavities were constructed. Nesting platforms for osprey were also erected. Rock piles for marmots were constructed along the Castle Arm of the reservoir.

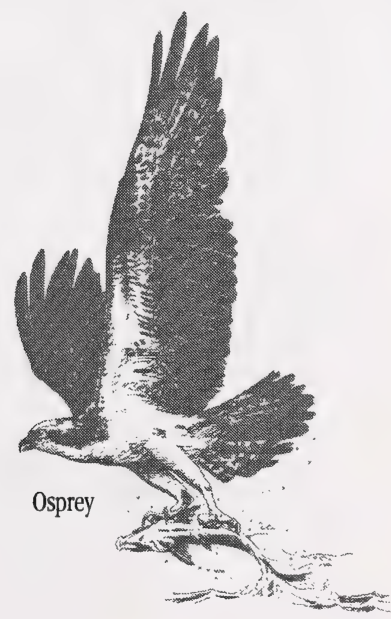




\section{Monitoring}

The monitoring program was designed to evaluate the success of the wildlife mitigation projects and assess the wellbeing of the indicator species. The mule deer was chosen as an indicator species for riparian habitat on the assumption that the well-being of this species would indicate the well-being of a variety of forest and shrublanddependent species. Waterfowl were used as indicators of the success of wetlands, and songbirds were used as indicators of the success of establishing native vegetation communities.

\section{What Was Done}

Mule deer studies: The productivity of the mule deer population in the vicinity of the reservoir, its movements and habitat use have been monitored to determine what effects the dam is having on this species. Winter aerial surveys were carried out four times from 1989/90 through 1993/94. Another aerial survey is planned for 1998/99. Between 1992 and 1996, 31 deer (mostly females) were radio-collared and subsequently followed with radiotelemetry. These radiotelemetry studies provided information on home range sizes and habitat use, particularly during fawning, when intensive radio-tracking was conducted.

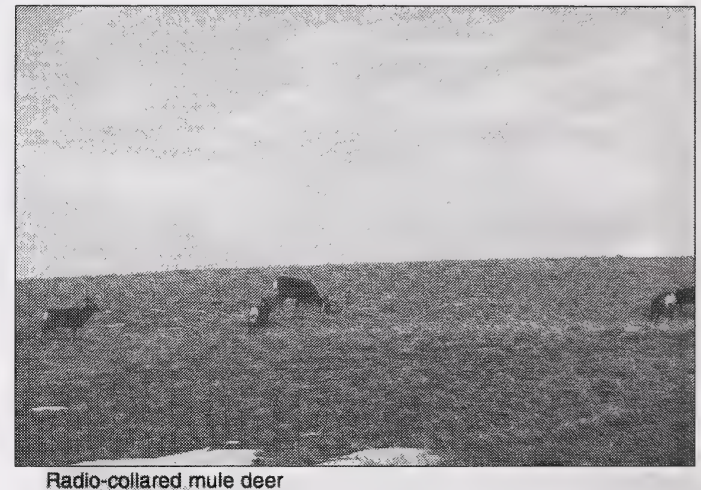

Radio-collared mule deer They also enabled fawning and mortality rates to be estimated. The aerial surveys combined with radiotelemetry provided more accurate population estimates. The capture program to install radio collars also permitted assessment of the condition of the deer.

Raptor studies: Intensive inventories and behavioral studies of the raptors in the vicinity began in 1989 to answer the following questions:

$\llcorner$ Are the raptors nesting successfully around the reservoir?

$\llcorner$ Are the artificial and improved cliff nesting sites and nesting platforms being used successfully?

$\llcorner$ Are nesting raptors being disturbed by human activities?

In 1993, the impact of recreationists on nesting raptors became a concern when anglers were seen boating under raptor nests, unaware of the stress this was causing the birds. The Environmental Monitoring Committee proposed the designation of Wildlife Control Areas in 1993 to provide additional protection to these nesting raptors. At the time, there were few such areas in the province. The Alberta Government acted on the recommendation in 1994, creating six Wildlife Control Areas under The Wildlife Act to protect nesting territories around the reservoir from disturbance. Bright orange buoys with signs now mark the areas, which vary in size from $100 \mathrm{~m} \times 350 \mathrm{~m}$ to $650 \mathrm{~m} \mathrm{x}$ $750 \mathrm{~m}$. The effectiveness of these control areas was subsequently monitored. 
Waterfowl/wetland studies: Early studies were directed at identifying waterfowl response to the filling of the reservoir. Later studies in 1995 and 1997 evaluated the use of the artificial wetlands by waterfowl and vegetative development in and around the artificial wetlands. The vegetation study examined approximately one-half of the wetlands by means of field survey and aerial photographs (Figure 15).

Breeding songbird survey: Many species have particular requirements and can therefore be used as indicators of the type and quality of habitat within a region. An assessment of bird populations in the various habitats surrounding the Oldman River Reservoir was carried out from 1990 to 1992. In 1997, more detailed surveys using the point count method were conducted to describe resident bird species composition, abundance and use of available habitats. Due to the difference in study methods, direct comparisons with the earlier study could not be made.

\section{What Was Found}

Mule deer: The mule deer population in the reservoir vicinity is productive and faring better than expected. Consisting of several herds that intermingle during the winter, the total population was estimated at 1000 in 1994 with an annual rate of growth of $11 \%$. Annual fawning rates have varied from 1.08 to 1.46 . From 1992 to 1996 an average of 1.33 fawns were produced per doe, a value similar to that found in a prairie environment in Montana. Fawn mortality in 1992 was 46\%. Doe mortality from 1992 to 1996 (including legal harvest during the hunting season) was $18 \%$.

The mule deer population is clearly non-migratory. Females occupy small multi-annual home ranges averaging $14 \mathrm{~km}^{2}$ and winter ranges averaging $8.2 \mathrm{~km}^{2}$. During the fawning season, does use the river valley cottonwood forests, coulee shrublands and grasslands on adjacent benchlands. They tend to return to the same general area for fawning each year.
To date only one radio-collared deer has left the 0ldman River Dam area. About $25 \%$ of the radio collars are still transmitting and these individuals are being monitored.

A total of 83 mule deer were captured and assessed during the radio-collaring program. All were in good to medium body condition. Evidence of hybridization with white-tailed deer was found in three of 66 blood samples taken. The significance of this for the local population is not clear at the present time.

Overall, these findings suggest that mule deer are highly adaptable to changing conditions and are thus not a good indicator species for the well-being of other terrestrial wildlife species in an altered environment.

Raptors: All of the raptorial species that nested in the vicinity of the reservoir before the dam was built have continued to nest there. The trend in number of nesting prairie falcons around the reservoir since 1968 is shown in Table 5. More intensive sampling beginning in 1989 is responsible for the rise in numbers beginning in that year. This level of nesting has been maintained in part because of the man-made cliff nesting sites. Use of these sites by prairie falcons peaked at a high of $10 \%$. (As several artificial nest sites were usually created within each falcon territory, a high occupancy rate was not expected).

Falcon productivity in the area has been good. 0ver 200 nestling prairie falcons have been banded since 1989. No returns have been received to date. In 1997, successful pairs produced an average of 4.0 young. 


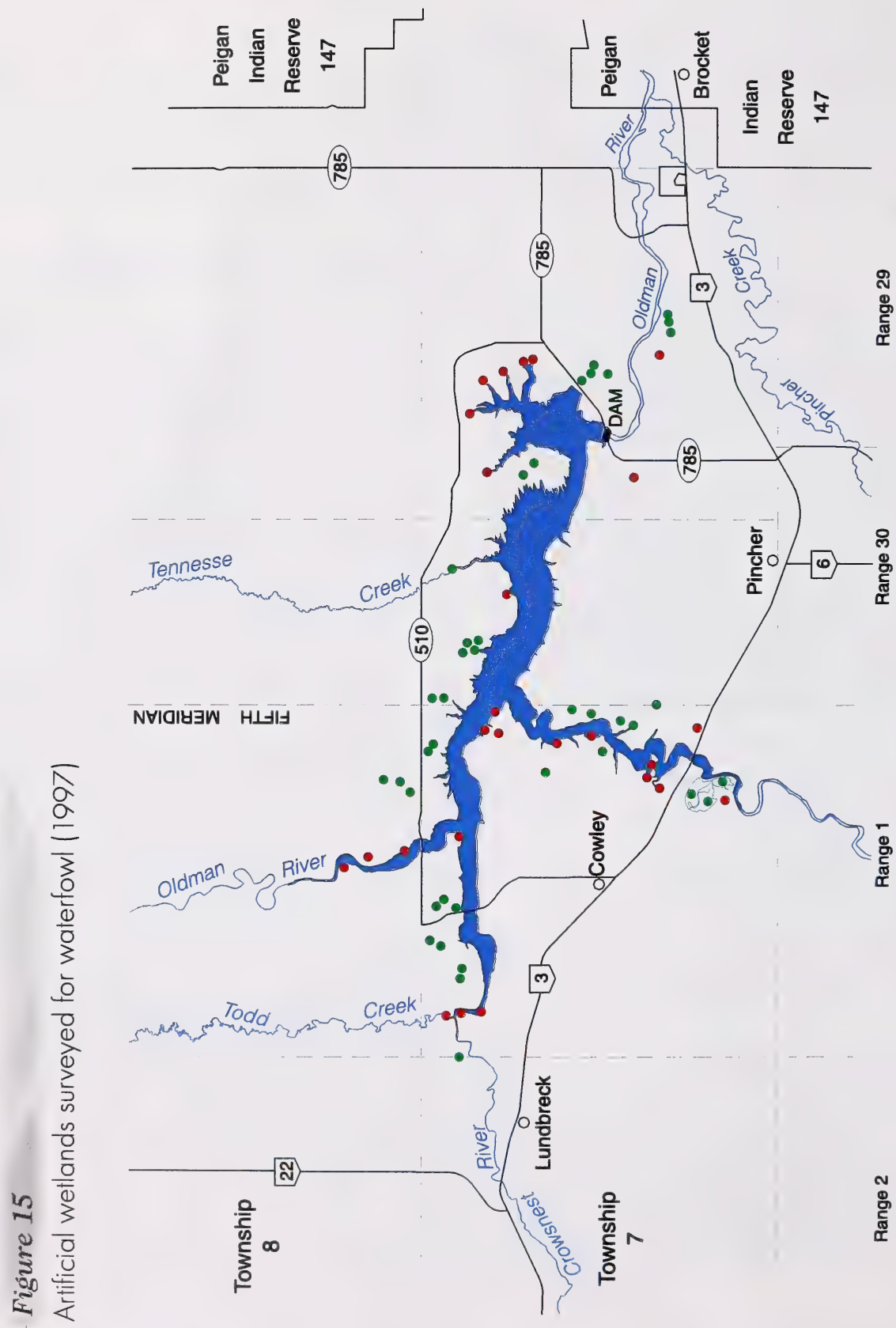

일 


\section{Table 5}

Prairie falcon nest occupancy 1968 - 1996

\begin{tabular}{|c|c|c|c|c|c|c|c|c|c|c|c|c|c|c|c|c|c|c|c|c|c|c|c|}
\hline Site & 68 & 69 & 70 & 71 & 72 & 73 & 74 & 75 & 76 & 77 & 78 & 80 & 85 & 86 & 87 & 89 & 90 & 91 & 92. & 93 & 94 & 95 & 96 \\
\hline 1 & $\mathrm{~F}$ & $\mathrm{~F}$ & 0 & $\mathrm{~F}$ & $\mathrm{~F}$ & $\mathrm{~F}$ & & & & & & & $\mathrm{~F}$ & $\mathrm{~F}$ & $\mathrm{~F}$ & $S$ & $\mathrm{~F}$ & $\mathrm{~F}$ & $\mathrm{~F}$ & $\mathrm{~F}$ & $\mathrm{~F}$ & $\mathrm{~F}$ & \\
\hline 2 & $\mathrm{~F}$ & $\mathrm{~F}$ & $\mathrm{~F}$ & S & & $\mathrm{F}$ & & $\mathrm{F}$ & $\mathrm{F}$ & $\mathrm{F}$ & $\mathrm{F}$ & $\mathrm{F}$ & $\mathrm{F}$ & $\mathrm{F}$ & $\mathrm{F}$ & $\mathrm{F}$ & $\mathrm{F}$ & $\mathrm{F}$ & & $\mathrm{F}$ & & & \\
\hline 3 & & & $\mathrm{~F}$ & $\mathrm{~F}$ & & & $\mathrm{~F}$ & & & & $\mathrm{~F}$ & $\mathrm{~F}$ & $S$ & $S$ & & $\mathrm{~F}$ & & 0 & & $S$ & & & $\mathrm{~F}$ \\
\hline 4 & $\mathrm{~F}$ & $\mathrm{~F}$ & & & & & $\mathrm{~F}$ & & $\mathrm{~F}$ & $\mathrm{~F}$ & $\mathrm{~F}$ & $S$ & $\mathrm{~F}$ & $\mathrm{~F}$ & $\mathrm{~F}$ & $\mathrm{~F}$ & $\mathrm{~F}$ & $\mathrm{~F}$ & $\mathrm{~F}$ & $\mathrm{~F}$ & $\mathrm{~F}$ & $\mathrm{~F}$ & $\mathrm{~F}$ \\
\hline 5 & & & & & & & & & & & & & & $\mathrm{U}$ & $\mathrm{U}$ & $\mathrm{F}$ & $\mathrm{F}$ & $\mathrm{F}$ & $\mathrm{F}$ & $\mathrm{F}$ & & & \\
\hline 6 & & & & & & & & & & & & & $\mathrm{~F}$ & $\mathrm{~F}$ & $\mathrm{~F}$ & $\mathrm{~F}$ & $\mathrm{~F}$ & 0 & & & & & \\
\hline 7 & & & & & & & & & & & & & & $\mathrm{U}$ & $\mathrm{U}$ & & $\mathrm{F}$ & & & & & & \\
\hline 8 & & & & & & & & & & & & & & $\mathrm{U}$ & $\mathrm{U}$ & $S$ & $\mathrm{~F}$ & $\mathrm{~F}$ & $\mathrm{~F}$ & & & & \\
\hline 9 & & & & & $\mathrm{~F}$ & $\mathrm{~F}$ & 0 & $\mathrm{~F}$ & 0 & $\mathrm{~F}$ & $\mathrm{~F}$ & & $\mathrm{~F}$ & $\mathrm{U}$ & $\mathrm{U}$ & $\mathrm{F}$ & $\mathrm{F}$ & $\mathrm{F}$ & $S$ & & & & \\
\hline 10 & & & & & & & $\mathrm{~F}$ & $\mathrm{~F}$ & $\mathrm{~F}$ & $\mathrm{~F}$ & $S$ & & $\mathrm{~F}$ & $\mathrm{U}$ & $\mathrm{U}$ & $\mathrm{F}$ & $\mathrm{F}$ & $\mathrm{F}$ & $\mathrm{F}$ & & & & \\
\hline 11 & & & & & & & & & & & & & & & & & $\mathrm{~F}$ & & & & & & \\
\hline 12 & $\mathrm{~F}$ & $\mathrm{~F}$ & 0 & 0 & 0 & 0 & 0 & 0 & 0 & 0 & 0 & & & $\mathrm{U}$ & $\mathrm{U}$ & $\mathrm{F}$ & $\mathrm{F}$ & $\mathrm{F}$ & $S$ & $\mathrm{~F}$ & $\mathrm{~F}$ & $\mathrm{~F}$ & $\mathrm{~F}$ \\
\hline 13 & & & & & & & $\mathrm{~F}$ & $\mathrm{~F}$ & $\mathrm{~F}$ & $\mathrm{~F}$ & & & $\mathrm{~F}$ & $\mathrm{U}$ & $\mathrm{U}$ & $\mathrm{F}$ & $\mathrm{F}$ & $\mathrm{F}$ & $\mathrm{F}$ & $\mathrm{F}$ & $\mathrm{F}$ & & $\mathrm{F}$ \\
\hline 14 & & & & & & & & & & & & & & & & $\mathrm{~F}$ & $\mathrm{~F}$ & $\mathrm{~F}$ & 0 & 0 & $\mathrm{~F} / 0$ & $\mathrm{~F}$ & \\
\hline 15 & & & & & & & & & & & & & & & & & $S$ & $S$ & $\mathrm{~F}$ & $\mathrm{~F}$ & 0 & 0 & $\mathrm{R}$ \\
\hline 16 & & & & & & & & & & & & & & & & $\mathrm{~F}$ & & & & $\mathrm{~F}$ & $\mathrm{~F}$ & $\mathrm{~F}$ & $\mathrm{~F}$ \\
\hline 17 & & & & & & & & & & & & & & & & & $\mathrm{~F}$ & $\mathrm{~F}$ & $\mathrm{~F}$ & $\mathrm{~F}$ & $\mathrm{~F}$ & & $\mathrm{~F}$ \\
\hline 18 & & & & & & & & & & & & & $\mathrm{~F}$ & & & $\mathrm{~F}$ & & $\mathrm{~F}$ & $S$ & & & & \\
\hline 19 & & $\mathrm{~F}$ & $\mathrm{~F}$ & $\mathrm{~F}$ & $\mathrm{~F}$ & $\mathrm{~F}$ & $\mathrm{~F}$ & $\mathrm{~F}$ & $\mathrm{~F}$ & $\mathrm{~F}$ & $\mathrm{~F}$ & $\mathrm{~F}$ & $\mathrm{U}$ & & & $\mathrm{F}$ & $\mathrm{F}$ & $\mathrm{F}$ & $\mathrm{F}$ & $\mathrm{F}$ & $\mathrm{F}$ & $\mathrm{F}$ & $\mathrm{F}$ \\
\hline Total F & 4 & 5 & 3 & 3 & 3 & 4 & 5 & 5 & 5 & 6 & 5 & 3 & 8 & 4 & 4 & 13 & 15 & 13 & 9 & 10 & 7 & 6 & 7 \\
\hline Total S & & & & 1 & & & & & & & 1 & 1 & 1 & 1 & & 2 & 1 & 1 & 3 & 1 & & & \\
\hline Total 0 & & & 2 & 1 & 1 & 1 & 2 & 1 & 2 & 1 & 1 & & & & & & & 2 & 1 & 1 & 2 & & \\
\hline \multicolumn{8}{|c|}{ No. of artificial nesting sites available } & & & & & & & & & 15 & 47 & 50 & 50 & 51 & 51 & 51 & 51 \\
\hline \multicolumn{8}{|c|}{ No. of artificial nesting sites used by falcons } & & & & & & & & & 1 & 5 & 4 & 3 & 5 & 4 & 3 & 3 \\
\hline
\end{tabular}

F - Pair of Prairie Falcons on territory

S - Single Prairie Falcon on territory

0 - Pair of Great Horned 0wls nesting in the territory

A small percentage of the artificial and improved cliff nesting sites have been used by other birds, including great horned owls, ferruginous hawks, Canada geese, and ravens. Nesting platforms have been used by osprey, ferruginous and red-tailed hawks and Canada geese.

\section{R - Ravens}

U - Unknown

Shading - Prairie Falcon territories flooded by the reservoir
The number of nesting pairs of ferruginous hawks increased to three in 1997. One pair of golden eagles has nested in the Provincial Recreation Area each year. Fledging of young eagles has been inconsistent; natural predation of eggs and young is suspected. 
Monitoring of the Wildlife Control Areas has shown that these areas have been respected by the public. Prairie falcons, golden eagles and waterfowl continue to nest successfully within or near these areas. On the other hand, human activity in the reservoir vicinity outside of the Provincial Recreation Area still poses a potential danger to nesting raptors. The future of the raptors in this area remains uncertain as subdivisions and other developments adjacent to the perimeter lands continue apace, eliminating the feeding grounds of these birds and increasing human encroachment around their nesting territories.

Waterfowl: As expected, the Oldman River Reservoir has attracted many waterfowl and other waterbirds. Numbers of geese, ducks, and colonial species increased dramatically soon after the reservoir was filled. The reservoir is used as a stop-over by migrating waterfowl on both northward and southward flights. It has also attracted white pelicans, double-crested cormorants, common loons, mergansers, western grebes, common and black terns, and California and ring-billed gulls during spring migration. Only the loons and cormorants remain to nest in the vicinity.

The reservoir does not provide good nesting habitat because of annual fluctuations in water level. To provide this habitat, artificial and enhanced wetlands were created, including check dams in coulees and depressions, riparian dams and dikes within the upper flood zone of the reservoir, and dugouts. A study of wetland use by waterfowl in the spring of 1995 and 1997 found 22 and 20 species using the artificial wetlands, respectively. Dabbling ducks (particularly mallard and blue-winged teal) comprised the large majority of the breeding pairs. The species assemblage of dabbling ducks observed was typical of prairie potholes, while that of diving ducks was more typical of parkland ponds. All of the 8 dabbling species observed stayed as breeding residents, while 5 of the 9 diving duck species remained. Pelicans, cormorants and seven species of shorebird were also observed on some ponds.
The wetlands most heavily used by breeding ducks were those created by check dams in shallow basins and gently sloping depressions. They ranged in size from 0.23 to 0.40 ha. After hatching, broods moved to shallow ponds that were larger than $0.40 \mathrm{ha}$. The greatest brood species richness was found on wetlands larger than 0.8 ha.

By the time of the 1995 vegetation survey, most artificial wetlands had developed beneficial submergent aquatic vegetation. However, many wetlands-particularly those in narrow coulees-lacked significant stands of emergent vegetation, thus limiting their use as hiding cover for moulting waterfowl. The riparian dike wetlands had lost water through the bottom substrate and thus provided only limited nesting habitat. Many wetland shorelines had been invaded by agricultural species typical of disturbed wetlands.

A variety of aquatic and wetland-associated wildlife species such as muskrat, frogs, shorebirds and wading birds were observed at the wetlands, as were terrestrial species such as deer, coyotes and raptors. However, it appears that many of the wetlands were too small to be of optimum wildlife value. Providing larger protected areas around the wetlands may increase the value for nesting waterfowl.

Songbirds: A total of 26 species of breeding resident songbirds was counted. Highest numbers and diversity were found in aspen and grassland habitats. Songbird assemblages for each habitat type were consistent with the scientific literature; however, the cottonwood forest habitat had fewer species than expected. This was probably due to habitat disturbances such as campgrounds and fragmentation of the forest. To restore bird diversity and abundance, controlling grazing and allowing shrub regrowth in these stands were recommended. The use of songbird species as long-term indicators of environmental health is being considered.

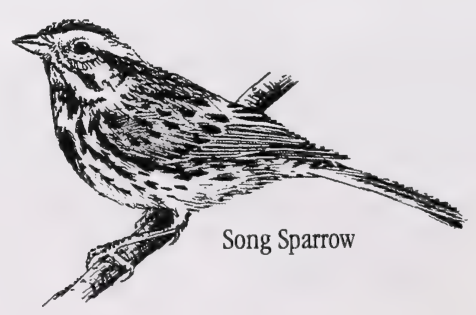




\section{Monitoring Timeline and Budget}

From 1992/93 through 1997/98 the wildlife component received \$239,800.

\begin{tabular}{|l|c|c|c|c|c|c|c|c|}
\hline & $91 / 92$ & $92 / 93$ & $93 / 94$ & $94 / 95$ & $95 / 96$ & $96 / 97$ & $97 / 98$ & $98 / 99$ \\
\hline Mule deer population & & $\mathrm{D} / \mathrm{R}$ & $\mathrm{D} / \mathrm{R}$ & & & & & $\mathrm{P}$ \\
\hline Mule deer fawning & & $\mathrm{D} / \mathrm{R}$ & & $\mathrm{D} / \mathrm{R}$ & $\mathrm{D} / \mathrm{R}$ & $\mathrm{D} / \mathrm{R}$ & $\mathrm{D} / \mathrm{R}$ & \\
\hline Mule deer movement & $\mathrm{D} / \mathrm{R}$ & $\mathrm{D} / \mathrm{R}$ & & $\mathrm{D} / \mathrm{R}$ & $\mathrm{D} / \mathrm{R}$ & $\mathrm{D} / \mathrm{R}$ & $\mathrm{R}$ & \\
\hline Mule deer habitat use & & $\mathrm{D} / \mathrm{R}$ & & & & & $\mathrm{R}$ & \\
\hline Raptors & $\mathrm{D} / \mathrm{R}$ & $\mathrm{D} / \mathrm{R}$ & $\mathrm{D} / \mathrm{R}$ & $\mathrm{D} / \mathrm{R}$ & $\mathrm{D} / \mathrm{R}$ & $\mathrm{D} / \mathrm{R}$ & $\mathrm{D} / \mathrm{R}$ & \\
\hline Waterfowl & $\mathrm{D} / \mathrm{R}$ & $\mathrm{D} / \mathrm{R}$ & & & $\mathrm{D} / \mathrm{R}$ & & $\mathrm{D} / \mathrm{R}$ & $\mathrm{P}$ \\
\hline Songbirds & $\mathrm{D} / \mathrm{R}$ & $\mathrm{D} / \mathrm{R}$ & $\mathrm{D} / \mathrm{R}$ & & & & $\mathrm{D} / \mathrm{R}$ & \\
\hline Colonial bird spp & & & & & $\mathrm{D} / \mathrm{R}$ & & & \\
\hline
\end{tabular}

D - data collected $\quad \mathrm{R}$ - report completed $\quad \mathrm{P}$ - Proposed monitoring

\section{Monitoring Reports}

Fyfe, R.W. 1994 (draft). Oldman River Dam Wildlife Control Area Monitoring Report. Prep. for Alberta Environmental Protection. 8 pp.

Fyfe, R.W. 1995. Raptor and Waterfowl Monitoring on the Oldman River Reservoir. Prep. for Alberta Environmental Protection. 21 pp.

Fyfe, R.W. 1997 (draft). 1997 Raptor Monitoring on the Oldman River Reservoir. Prep. for Alberta Environmental Protection. $16 \mathrm{pp}$.

Herzog, P.W. 1998 (draft). Bird Community Structure and Habitat Use in the Oldman River Reservoir Region MayJune 1997. Prep. for Alberta Environmental Protection. 29 pp.

Herzog, P.W. 1998. Waterfowl Use of Wetland Mitigation Projects at the Oldman River Reservoir May - August 1997. Prep. for Alberta Environmental Protection. 77 pp.

Hornbeck, G.E. 1994. Aerial Survey of the Oldman Reservoir, Southwestern Alberta, 28 February to 1 March. Prep. by Axys Environmental Consulting Ltd. for Alberta Environmental Protection. 29 pp.

Hornbeck, G.E. 1994. Oldman Reservoir Mule Deer Studies - Capture and Radio-collaring, Winter 1993-94. Prep. by Axys Environmental Consulting Ltd. for Alberta Environmental Protection. 21 pp.

Hornbeck, G.E. 1995. Oldman Reservoir Mule Deer - Report on Fawn Studies, 1992 to 1995. Prep. by Axys Environmental Consulting Ltd. for Alberta Environmental Protection. 43 pp. 
Hornbeck, G.E. 1996. Oldman Reservoir Mule Deer, Procedures for Continued Monitoring of Herd Productivity. Prep. by Axys Environmental Consulting Ltd. for Alberta Environmental Protection. 13 pp.

Hornbeck, G.E. 1998. The Oldman River Dam Mule Deer. Prep. by Wildlife \& Company Ltd. in assoc. with Axys Environmental Consulting Ltd. for Alberta Environmental Protection. 53 pp. + App.

Pichlyk, M. 1996. Oldman River Dam Wildlife Habitat Mitigation Program. Preliminary Survey of Wetland Habitat Projects, 1995. Prep. for Alberta Environmental Protection. 63 pp.

\section{References and Other Selected Reports ${ }^{1}$}

Green, J.E. and T.R. Eccles. 1989. A Strategy for Wildlife Habitat Mitigation for the Oldman River Dam. Prep. by Delta Environmental Management Group Ltd. for Alberta Public Works, Supply and Services. 36 pp.

Green, J.E., P. Jalkotzy, R. Berger and T. Van Egmond. 1990. A Monitoring Program for the Oldman River Wildlife Habitat Mitigation Program. Prep. by Delta Environmental Management Group Ltd. for Alberta Public Works, Supply and Services. 76 pp. + App.

Green, J.E., T. Van Egmond and R. Berger. 1991. The Oldman River Dam Wildlife Evaluation and Monitoring Program. Prep. by Delta Environmental Management Group Ltd. for Alberta Public Works, Supply and Services. 71 pp.

Hornbeck, G.E. and R.D. Lauzon. 1991. Wildlife Surveys of the Oldman Reservoir and Its Perimeter during Initial Filling, Spring 1991. Prep. by Delta Environmental Management Group Ltd. for Alberta Public Works, Supplies and Services. 35 pp. + App.

Hornbeck, G.E. and P. Balagus. 1992. Aerial Surveys of the Oldman Reservoir, Southwestern Alberta, 1990 and 1991. Prep. by Delta Environmental Management Group Ltd. for Alberta Public Works, Supplies and Services. 37 pp.

Hornbeck, G.E and P. Balagus. 1992. Oldman Reservoir Mule Deer Studies - Progress Report on Capture and Radiocollaring, Winter 1991-92. Prep by the Delta Environmental Management Group Ltd. for Alberta Public Works, Supply and Services. 15 pp. + App.

Hornbeck, G.E. and P. Balagus. 1992. Oldman Reservoir Mule Deer Studies - Progress Report on Fawn Studies, 1-12 June. Prep. by Delta Environmental Management Group for Alberta Public Works, Supply and Services. 29 pp.

Hornbeck, G.E., P. Balagus and G.M. Goulet. 1993. Mule Deer Browse and Pellet Group Surveys of the Oldman Reservoir, 1990-91. Progress Report. Prep. by Delta Environmental Management Group Ltd. for Alberta Public Works, Supplies and Services. $49 \mathrm{pp}$.

Hornbeck, G.E. and P. Balagus. 1993. Aerial Survey of the Oldman Reservoir, Southwestern Alberta, 1 to 3 February 1993. Prep. by the Delta Environmental Management Group for Alberta Public Works, Supply and Services. $36 \mathrm{pp}$.

Hornbeck, G.E., P. Balagus and R. Lauzon. 1993. Oldman Reservoir Mule Deer Studies - Progress Report on Fawn Studies, 4-8 June. Prep. by Delta Environmental Management Group for Alberta Public Works, Supply and Services. $26 \mathrm{pp}$.

Nilson, A.L. and J.E. Green. 1989. An Action Plan for Wildlife Habitat Mitigation for the Oldman River Dam Reservoir. Prep. for Alberta Public Works, Supplies and Services. 16 pp. + maps.

$1_{\text {not a complete listing of pre-monitoring phase reports }}$ 
Background

\section{Initial Concerns}

River valleys support the only forests present in the grassland region in which the Oldman River Dam is situated. These forests are essential to a diverse assemblage of wildlife species, and their loss in the reservoir area means a loss of wildlife. The predominant tree species in these forests are cottonwoods. These species are adapted to and dependent upon stream flow. Studies have shown that cottonwood forests downstream of some dams have suffered severe declines.

Much of the land set aside for wildlife around the reservoir was grassland that had been heavily grazed, and many of the native plant species there had been eliminated or suppressed. In addition to the need to restore this area, the construction zone around the dam required revegetation.

\section{cottonwoods}

The term "cottonwoods" refers to three poplar species - Populus deltoides ("prairie cottonwood"), Populus balsamifera ("balsam poplar"), and Populus angustifolia ("narrowleaf cottonwood") - and the hybrids which they form.
\end{abstract}

\section{Mitigative Action}

Projects were undertaken to protect and enhance existing habitat and to create new habitat on the mitigation land base around the reservoir as described below.

Snow fencing on uplands: To aid recovery of vegetation on areas that had been heavily grazed, snow fences were erected along perimeter fences in the expectation that they would increase soil moisture which in turn would encourage the recovery of native plant communities.

Tree and shrub planting: Approximately 250,000 tree and shrub seedlings and rooted cuttings were planted between 1989 and 1993. Some of these were planted next to checkdams so that trickle irrigation could be provided to the seedlings.

Revegetation of the dam: The steep slopes and south-facing aspect of the dam face create a harsh environment for revegetation, and methods for such an environment are not well documented in the literature. Native topsoil from a native grassland area within the reservoir site was placed on the face of the dam in the expectation that the seedbank within the soil would germinate and native plants would thus become established.

Grazing management plan: A major component of the wildlife mitigation program was the development of a grazing management plan. This plan, based on a grazing inventory completed in 1991, seeks to maintain rangelands at optimum condition for grassland and shrub-associated wildlife while allowing limited grazing opportunities for adjacent landowners. It is also expected to provide more residual cover for songbirds, small mammals and insects. The plan was implemented by Alberta Public Works, Supply and Services during 1991 and 1992. 


\section{Monitoring}

Monitoring of projects begun in the mitigation phase was done to ensure that the overall objective of wildlife habitat enhancement and replacement is being achieved and to evaluate the effectiveness of the various techniques used in revegetation.

\section{What Was Done}

Snow fencing evaluation: Soil moisture levels in snow-fenced and unfenced (control) areas were measured in 1990 and again in fall of 1993, 1994, and summer of 1995. It was expected that increased soil moisture from the snow fences would bring about a change in vegetation, either in species present or in productivity. Findings from the 1998 field season will be compared to baseline data gathered before the snow fences were erected.

Mitigation planting survival: A sample of planting project locations was examined in 1994 and 1995 to see how well the plantings had done. Data were collected on survival, planting technique used, and location of planting site.

Effect of exclosures on grassland recovery: Data were collected in 1994 from exclosures set up to eliminate browsing and grazing by deer as part of the habitat mitigation program. Baseline data had been collected in 1989 and 1990 when the exclosures were erected.

Vegetation establishment on the dam face: To determine the effectiveness of the technique used, vegetation surveys of plant species present are required at regular intervals. A resurvey was completed in

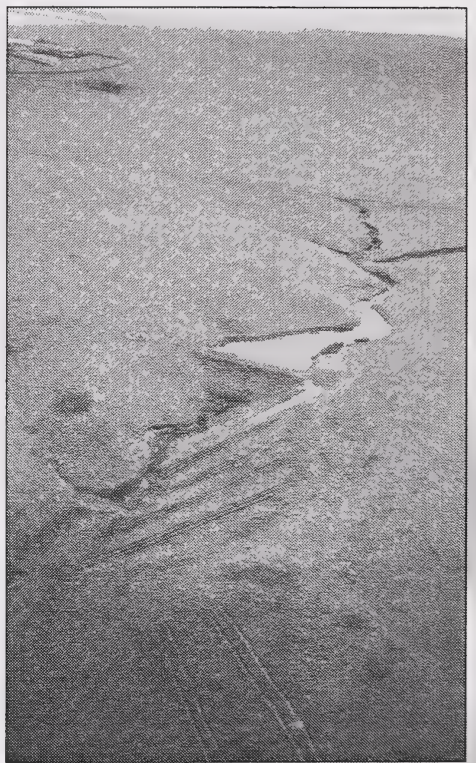

Mitigation planting (strips) adjacent to checkdam wetland 1994 following an initial survey in 1991.

Riparian cottonwoods: Monitoring of the production, germination and survival of riparian cottonwood seeds along various rivers in southern Alberta to determine natural rates of productivity began in 1989. Additional research has been conducted since then to determine the river flow needed to encourage the establishment of cottonwood seedlings and how river flows affect popular growth.

A unique opportunity to document the effects of large floods on riparian cottonwoods occurred in 1995. A detailed study was conducted throughout the Oldman River Basin to measure seedling establishment and growth after the June flood.

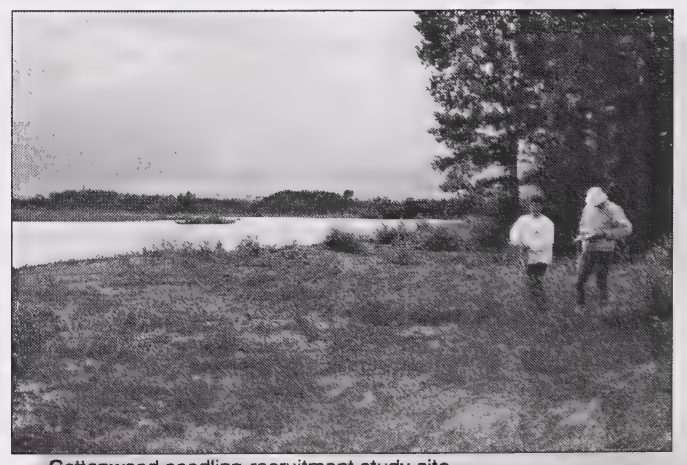

Cottonwood seedling recruitment study site 
Land management: Changes in vegetation, land condition, drainage patterns and soil condition are readily seen on airphotos. A program of acquiring airphotos on a regular basis allows the manager to evaluate changes in a large number of areas over a period of time. Airphotos were first taken in 1991 to provide baseline information on the perimeter lands. Four years later the same areas were photographed again so that changes in natural and planted vegetation could be determined. This program should be repeated in about the year 2000 .

A ground survey will also be needed to determine whether the grazing management program has had the desired effect. Monitoring of compliance with the grazing management plan and land use agreements and assessment of livestock damage to trees, shrubs and ground cover is done annually.

\section{What Was Found}

Snow fencing: A trend toward higher soil moisture to the lee of snow fences was seen, particularly at moderate depths in drier years. However, the retained moisture was not necessarily passed on from year to year; there was little difference in moisture levels at the end of a dry year.

Mitigation planting survival: The average survival of the planted seedlings was $45 \%$, with aspen, chokecherry and saskatoon showing the highest survival rate and Douglas fir and Northwest poplar the lowest. In spite of good growing conditions in 1994 through 1997, shrubs have shown little increase in size. The larger planting stock showed more vigorous growth than the smaller stock. The main factors affecting survival and growth were competing vegetation, deer browsing, and insufficient moisture. Irrigation was conducted after initial plantings but was mostly discontinued in 1994. Control of wildlife damage and competing vegetation will be necessary to ensure future survival of the plantings.

Vegetation establishment on the dam face: Vegetation became established on the dam face more rapidly than expected and density is approaching that of a natural grassland nearby. Diversity is also increasing: a survey in 1994 found 29 plant species as compared to 13 in 1991. Most of the increase was in early seral species. Invasion of weed or forage species is not a problem yet although some weed species are present. Monitoring will be needed to determine when weed control may be necessary.
Effect of exclosures on mitigation plantings: Exclosures did not appear to help native grassland species as the protected sites were dominated by invasive and highly competitive species. The survival of planted material did not appear to be improved by protection from deer herbivory. However, the plants that survived within the exclosures appear more vigorous than those outside.

Riparian cottonwoods: On average, favourable circumstances for germination and establishment of cottonwoods in the Oldman River Basin occur once in every ten years, although favourable years may be clustered together. In years when sufficient water is available, the instream needs for cottonwood seedling establishment are taken into consideration in the operation of the Oldman River Dam. Successful seedling establishment requires a gradual decline in river flows during the period of seed release until summer operating levels are reached. The opportunity to operate for the benefit of cottonwoods occurred each year between 1994 and 1997.

In Table 6 the rates of reduction in Oldman River flows during the critical period following seed release are compared to the recommended rates for seedling survival. In the summer of 1990, before the dam was operating, changes in flow were within acceptable levels $55 \%$ of the time and seedlings failed to establish. In contrast, from 1994 through 1997 flows were within acceptable limits over $85 \%$ of the time and seedlings established successfully each year. These were years of above-average flows and seedlings would probably have established naturally. Even so, these results indicate that operation of the dam is allowing for establishment of cottonwood seedlings in such years. 


\section{Table 6}

The percentage of time daily rates of change in stream flow of the Oldman River at Brocket met requirements for establishment of cottonwood seedlings during the critical period following seed release

\begin{tabular}{|l|c|c|c|c|c|}
\hline Rate of Flow Reduction & 1990 & 1994 & 1995 & 1996 & 1997 \\
\hline Acceptable & 55 & 90 & 80 & 95 & 75 \\
\hline Marginal & 26 & 10 & 17 & 5 & 15 \\
\hline Undesirable & 19 & 0 & 3 & 0 & 10 \\
\hline
\end{tabular}

The flood of 1995 produced a massive germination of cottonwood seedlings along the Oldman and South Saskatchewan rivers. During the following two years these underwent a natural thinning process, leaving a good number of live seedlings. The flood also promoted clonal replenishment of poplars. Growth and survival of the new trees will continue to be monitored.

The study of branch growth in cottonwoods showed that year-to-year variation in branch growth can be accounted for by spring stream flow and June evaporation. Water was the major factor in the growth of these trees, and the source of the water was shown to be the riparian water table.

\section{Monitoring Timeline and Budget}

From 1992/93 through 1997/98 this component received \$110,000.

\begin{tabular}{|l|c|c|c|c|c|c|c|c|}
\hline & $91 / 92$ & $92 / 93$ & $93 / 94$ & $94 / 95$ & $95 / 96$ & $96 / 97$ & $97 / 98$ & $98 / 99$ \\
\hline Cottonwoods & $\mathrm{D}$ & $\mathrm{D} / \mathrm{R}$ & $\mathrm{D}$ & $\mathrm{D} / \mathrm{R}$ & $\mathrm{D} / \mathrm{R}$ & $\mathrm{D} / \mathrm{R}$ & $\mathrm{D}$ & $\mathrm{P}$ \\
\hline Mitigation plantings & & & & $\mathrm{D} / \mathrm{R}$ & $\mathrm{D} / \mathrm{R}$ & & & \\
\hline Snow fence evaluation & & & $\mathrm{D} / \mathrm{R}$ & $\mathrm{D} / \mathrm{R}$ & $\mathrm{D} / \mathrm{R}$ & & $\mathrm{D}$ & $\mathrm{P}$ \\
\hline Dam revegetation & $\mathrm{D}$ & & & $\mathrm{D} / \mathrm{R}$ & & & & \\
\hline Grazing inventory & $\mathrm{D}$ & & & & & & & \\
\hline Wetland vegetation & & & & & $\mathrm{D} / \mathrm{R}$ & & & \\
\hline Airphotos & & $\mathrm{D} / \mathrm{R}$ & & & $\mathrm{D} / \mathrm{R}$ & & & \\
\hline
\end{tabular}

D - data collected $\quad$ R - report completed $\quad$ P - Proposed monitoring 


\section{Monitoring Reports}

Gom, L.A., A.R. Kalischuk, J. Willms, W. Willms, M. Tyree and S.B. Rood. 1997. Oldman River Basin - Riparian Cottonwoods. Prep. for Alberta Environmental Protection. 53 pp.

Pichlyk, M. 1996. Oldman River Dam Wildlife Habitat Mitigation Program - Assessment of Planted Tree and Shrub Seedlings, 1994-1995. Prep. for Alberta Environmental Protection. 87 pp.

Rood, S.B., L.A.Gom, A.R.Kalischuk and K.P. Zanewich. 1996. A River Ran Through It: Recruitment of Riparian Cottonwoods in the Oldman River Basin. Prep. for Alberta Environmental Protection. 34 pp.

Smreciu, A. and R. Yakimchuk. 1994. Native Plant Community Establishment on the Oldman River Dam - Progress Report 1994. Prep. by Wild Rose Consulting, Inc. for Alberta Environmental Protection. 14 pp. + App.

Smreciu, A. and R. Yakimchuk. 1996. Soil Moisture Levels - 1995 Oldman River Dam. Prep. by Wild Rose Consulting, Inc. for Alberta Environmental Protection. 12 pp.

\section{References and Other Selected Reports ${ }^{1}$}

Mahoney, J.M. and S.B. Rood. 1993. The Potential Effects of an Operating Plan for the Oldman River Dam on Riparian Cottonwood Forests. Oldman River Dam Mitigation Program. Project Rept. Vol II. Prep. for Alberta Public Works, Supply and Services.

Smreciu, A. and J. Hobden. 1992. Oldman River Dam, Wildlife Habitat Mitigation - Vegetation Studies and Surveys, 1989 - 1991. Prep. for Alberta Public Works, Supply and Services. 104 pp.

$\mathbf{1}_{\text {not a complete listing of pre-monitoring reports }}$

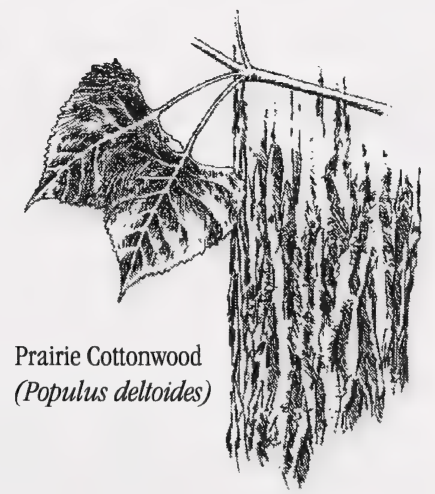




\section{Sociological and Recreation Aspects}

\section{Background}

\section{Initial Concerns}

The impact of the dam on local residents was one of the first concerns raised. A study in the late 1970s had predicted a significant amount of social costs and losses resulting from the construction of the Oldman River Dam at its present site. In addition to the obvious loss of land, it was predicted that there would be less tangible impacts on area residents such as loss of social relationships, uncertainty about the future, and increased travel time. Additionally, local residents would no longer have the river valley for fishing, hiking, wildlife viewing, camping, and other recreational activities.

\section{Mitigative Action}

The Local Advisory Committee and six subcommittees engaged in extensive public consultation in their work to mitigate the adverse impacts of the dam on the local community. The many issues handled and projects accomplished by these committees in co-operation with government staff are beyond the scope of this report. A few examples are the preservation of the area's history (as described in the Historical Resources section), design of a new system of local roads, and development of a grazing management plan for land surrounding the reservoir.

In 1985 the Oldman River Dam Local Advisory Committee and the M.D. of Pincher Creek initiated a survey of the effects of the dam on the population and land uses in the immediate vicinity of the damsite. Phase I of the survey, carried out in 1985 prior to dam construction, consisted of population and land use surveys. Phase II of the survey was carried out nine years later (see below).

A Recreation Mitigation Program was also developed by Alberta Public Works, Supply and Services in collaboration with the Local Advisory Committee, Recreation Subcommittee, several provincial government departments, the Oldman River Regional Planning Commission and various local groups. The purposes of the program were to replace lost recreation facilities, permit safe public access to the reservoir, and take advantage of recreation and tourism opportunities. After assessing the reservoir's recreational capability, consultants drew up draft plans and options which were reviewed by the Recreation Subcommittee in consultation with area residents and groups. The subcommittee reviewed the options, made recommendations and worked with project staff and consultants on detailed site plans.

A recreation facility was provided on each arm of the reservoir, as recommended by the Local Advisory Committee. Facilities developed in conjunction with the project include:

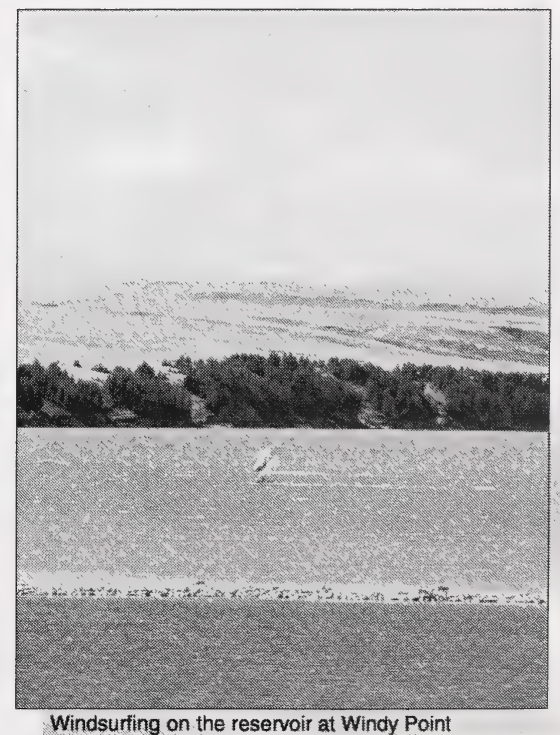

Windsurfing on the reservoir at Windy Point 
$\llcorner$ three campgrounds, including conversion of the construction camp to 160 -unit R.V. park

$\llcorner$ seven day use areas

$\llcorner$ six boat launches

$\llcorner$ a canoe and kayak slalom course

$\llcorner$ a beach area intended primarily for windsurfers.

\section{Monitoring}

\section{What Was Done}

Social impact survey: Phase II of the survey was commissioned in 1994 by the Alberta Government, the Environmental Advisory Committee, and the M.D. of Pincher Creek. An attempt was made to contact and interview all landowners who remained, emigrated from, or immigrated to the reservoir study area after the Phase I survey. Of 119 landowners contacted, 111 were interviewed.

Recreational facility use: Use of campgrounds has been recorded by Natural Resources Service, AEP.

\section{What Was Learned}

Social impact survey: The major findings of the Phase II study are summarized below:

$L$ The total number of landowners-mainly ranchers and farmers-who left the area between 1985 and 1994 was surpassed by the number of people who purchased land during that period. Most purchasers built or planned to build seasonal homes, second homes or retirement homes in newly created subdivisions and acreages.

$L$ In spite of the increase in landowners, the total year-round resident population decreased. This decrease occurred in all age brackets: adults, pre-school and school-aged children.

$L$ Remaining landowners varied in their assessment of the dam's impact on their lives. Approximately one-half indicated that there was no major impact . Others cited negative impacts such as stress/uncertainty during the project; altered lifestyle and social life; and altered road system or increased traffic affecting their farming operations.

$\llcorner$ of the 28 landowners who had moved from the area after the first survey, 18 cited dam construction as the reason for their move. Most of the latter group indicated that it had been a stressful time because of uncertainty about the future (including government procedures), loss of neighbours and loss of scenic environment. A few stated their new location was an improvement.

$\llcorner$ Many of those who had purchased land in the area since 1985 cited proximity to a variety of recreational opportunities as their chief reason for purchasing.

$\llcorner$ Most remaining and new landowners liked the new road system but had concerns about road maintenance and security problems resulting from increased access. Many also noted the current abundance of wildlife in the area. 
Recreational Facility Use: A total of 4,551 individual camper nights were recorded between April 1995 and March 1996 at the three camping facilities at the Oldman River Reservoir. Two of these facilities were damaged by the June flood and had to be repaired. The following year this total rose to 8,458 .

\section{References and Other Selected Reports ${ }^{1}$}

Boothroyd, P., Kupfer, G. and B. Lagin. 1978. Oldman River Basin Study: Phase 2 Social Impact Assessment. Alberta Environment.

Cerney, L. 1994. Oldman River Dam Social and Landuse Impact Study. Prep. for Oldman River Dam Environmental Advisory Committee and M.D. of Pincher Creek.

Christensen, M. 1985. Oldman River Dam Project Survey/Census.

Macklin, M., Monaghan Western Ltd. and Wood Bay Consulting Group Ltd.1987. Oldman River Reservoir: Recreation - Tourism Report. Phase I, Inventory and Assessment. Phase II, Recreation Development Opportunities, Concept Albernatives.

Wood Bay Consulting Group Ltd. 1987. Oldman River Reservoir: Recreation - Tourism Report. Phase III, A Recommended Development Opportunities Concept Plan.

$1_{\text {not a complete listing of pre-monitoring reports }}$

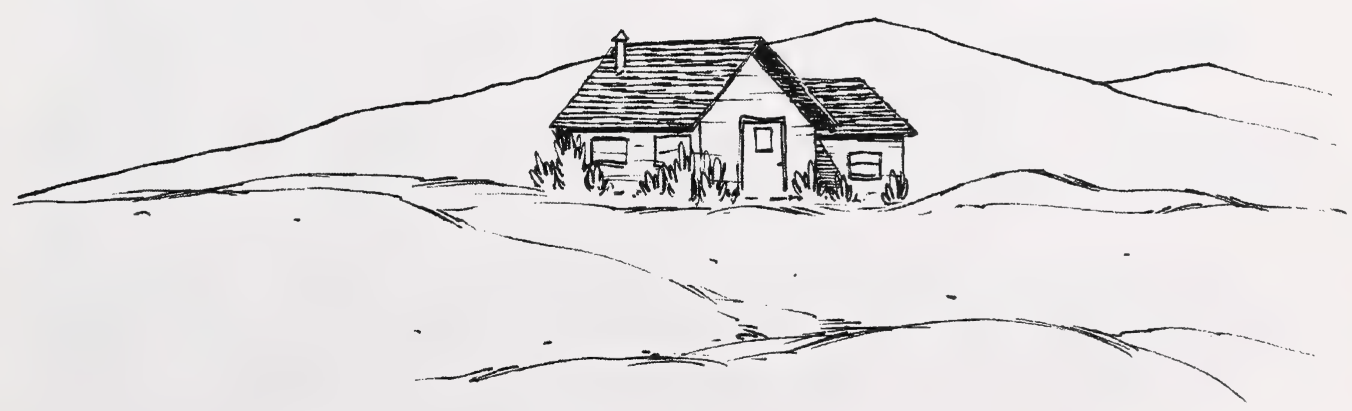




\section{Operation of the Oldman River Dam}

\section{Background}

The strategy and plan which govern the operation of the Oldman River Dam came into effect in June, 1994. The strategy ensures that the dam will supply existing and future consumptive water needs of municipalities, industries and agriculture and will provide downstream flows capable of maintaining water quality to ensure fish survival, enhancing downstream fish habitat and recreational opportunities, and sustaining riparian vegetation.

Existing policy and legislation influenced the development of the strategy in many ways. The Water Management Policy for the South Saskatchewan River Basin, adopted by the Alberta Government in 1990, states that river flows in the South Saskatchewan River Basin will be established on an individual river reach basis to protect aquatic life and ensure fish survival. Other instream flow needs, such as fish habitat, riparian vegetation and recreational use, can be included. The Water Resources Act (then in effect) set water use priority on a first in time, first in right basis. A regulation under this Act set limits for irrigation expansion. The Water Management Policy for the South Saskatchewan River Basin provides for a review of these limits in the year 2000.

In addition, an interprovincial agreement signed in 1969, the Master Agreement on Apportionment, allows Alberta to consume, divert, or store $50 \%$ of the natural annual flow in the South Saskatchewan River Basin or 2.59 million dam 3 , whichever is greater. A specified minimum flow must be maintained at the Alberta-Saskatchewan border. This requirement has priority over water rights licenced after 1969.

\section{How the Operating Guidelines Were Developed}

The operating guidelines for the Oldman River Dam incorporate the scientific knowledge acquired during the late 1980s and early 1990s as described previously in this report. The first step in developing the guidelines was to estimate the flow needs of all intended users of the water supply. This was done as follows:

L Municipal, domestic and industrial water needs were estimated and assumed to remain constant.

$\llcorner$ Estimates for irrigation were based on an irrigated land base equal to $90 \%$ of the prescribed limits (see below).

$\llcorner$ Water quality needs were developed for critical reaches (Table $7 \mathrm{a}$ ).

$L$ Estimates were developed for fish survival and fish habitat needs (Table $7 b$ ).

$\llcorner$ Recreational boating needs for different river reaches downstream of the dam were established for May through September (Table 7c).

$L$ Flow requirements for riparian vegetation were specified after the operating plan was in place and are currently implemented on a voluntary basis as the opportunities arise (see Vegetation section).

Reservoir level guidelines for safety and recreation purposes were also taken into account. Recreational facilities on the reservoir were assumed to be functional at reservoir levels ranging from full supply level to $8.6 \mathrm{~m}$ below FSL.

This assortment of flow requirements, reservoir level criteria and water supply priorities provided the input for a computer simulation of water supply and use in the South Saskatchewan River Basin. As this basin contains an extensive network of dams, diversions, canals, and water storage reservoirs, various scenarios representing different ways of operating the entire water management system were developed and tried in the simulation. The flow 
conditions used in the simulation consisted of all historical river flows occurring between 1928 and 1986. The simulation output showed what would have occurred during each of these years if the 0ldman River Dam and other water management infrastructure in the basin had been in place. The results of each simulation were evaluated and the scenarios refined in order to obtain the desired results as closely as possible.

The Environmental Advisory Committee was given the mandate of providing advice to the Minister of the Environment on how to operate the dam from 1994 to 2000. The Committee reviewed the proposed scenarios and instream needs studies and recommended the most desirable scenario. This scenario, with some refinements, became the basis for the present operating strategy. Computer simulation results for the scenario predict that, for any flow conditions between 1928 and 1986, water requirements would be met as follows:

$L$ apportionment - The Master Agreement on Apportionment is met each year. An average of $63 \%$ of the annual flow of the Oldman River is now passed to Saskatchewan, as compared to a pre-impoundment average of $80 \%$.

$L$ domestic and municipal - All needs are met.

$L$ water quality - Flow needs are met or exceeded (see Water Quality section).

$L$ irrigation - The occasional deficits that might occur in dry years meet the criteria for acceptable annual crop application deficits set by Alberta Agriculture, Food and Rural Development.

$\llcorner$ fish habitat - Flow needs are met on a statistical, not real time, basis by utilizing reservoir spills and modifying the reservoir operating guidelines to optimize spills for fish habitat in certain months.

$\llcorner$ recreation - The Oldman River Reservoir will reach full supply level in over $80 \%$ of the years and will be maintained above the minimum level for access to boat launches over $85 \%$ of the time from May through August. Downstream recreational opportunities will be improved over pre-dam conditions.

$\llcorner$ riparian vegetation - Large spring flows, when they occur, may still result in flood conditions downstream of the dam. After such occurrences, the rate of reduction of flow necessary for cottonwood seedling survival is sufficiently gradual to allow cottonwood seedlings to survive (see Vegetation section).

\section{How the Dam is Operated}

The operating guidelines for reservoir levels are shown in Figure 16. When the reservoir is at or above the spill line, excess water is released. If the reservoir is below the spill line, water is released according to downstream flow requirements. Abrupt changes between months in minimum flow requirements have been smoothed out. When the reservoir elevation is in one of the special flow release zones for fish habitat, the specified flow release is made during that month or until the reservoir elevation drops below the zone. 


\section{Figure 16}

Operating guidelines for Oldman River Reservoir levels ${ }^{1}$

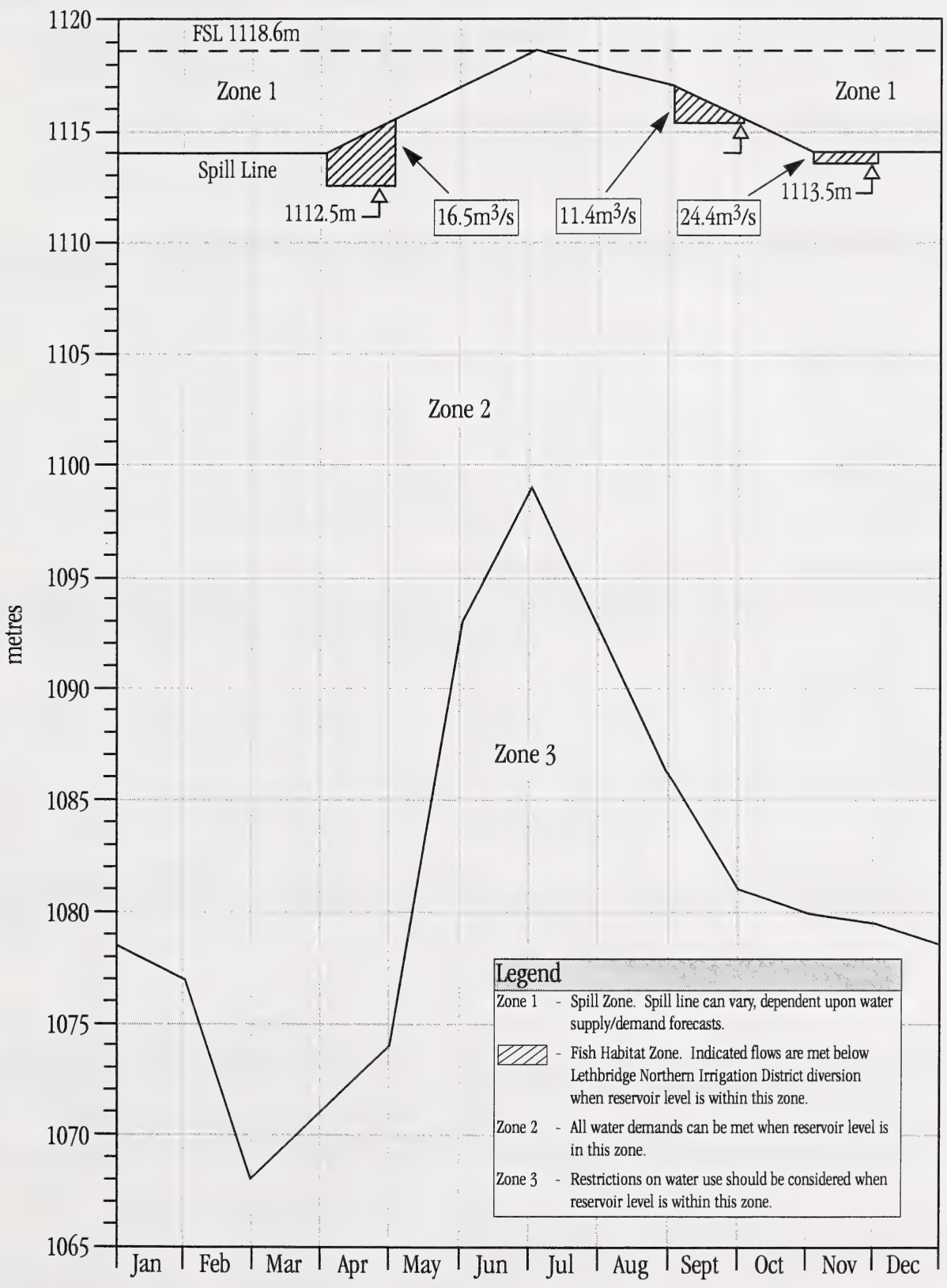

I These guidelines are applicable for the level of irrigation development assumed for scenario SS 2000 


\section{Future Operations}

The 1994 operating plan will be in effect until the year 2000, when it will be reviewed in conjunction with the review of irrigation expansion and the new Water Act. Findings of the present monitoring studies will be an important part of this review. Public involvement in preparing revisions to the operating plan will be solicited.

\section{Table 7}

Instream flow requirements used in developing operating plans for the Oldman River Dam a) Flow requirements for water quality $\left(\mathrm{m}^{3} / \mathrm{s}\right)$

\begin{tabular}{|l|c|c|c|c|c|c|c|c|c|c|c|c|}
\hline Reach & Jan & Feb & Mar & Apr & May & Jun & Jul & Aug & Sep & Oct & Nov & Dec \\
\hline $\begin{array}{l}\text { Downstream of } \\
\text { Lethbridge Northern } \\
\text { Irrigation Diversion }\end{array}$ & 6.5 & 6.5 & 6.5 & 8.5 & 8.5 & 8.5 & 8.5 & 8.5 & 8.5 & 8.5 & 6.5 & 6.5 \\
\hline $\begin{array}{l}\text { Downstream of } \\
\text { City of Lethbridge }\end{array}$ & 11.5 & 11.5 & 11.5 & 15.0 & 20.0 & 20.0 & 20.0 & 20.0 & 15.0 & 15.0 & 11.5 & 11.5 \\
\hline
\end{tabular}

b) Flow requirements for fish survival and habitat $\left(\mathrm{m}^{3} / \mathrm{s}\right)$

\begin{tabular}{|l|c|c|c|c|c|c|c|c|c|c|c|c|}
\hline Location & Jan & Feb & Mar & Apr & May & Jun & Jul & Aug & Sep & Oct & Nov & Dec \\
\hline $\begin{array}{l}\text { At Fort Macleod } \\
\text { (fish survival) }\end{array}$ & 6.5 & 6.5 & 6.5 & 8.5 & 8.5 & 9.0 & 8.5 & 8.5 & 8.5 & 8.5 & 6.5 & 6.5 \\
\hline $\begin{array}{l}\text { At Fort Macleod } \\
\text { (fish habitat)* }\end{array}$ & - & - & - & 10.0 & 10.0 & $\begin{array}{c}10.0 / \\
8.5^{* *}\end{array}$ & 8.5 & 8.5 & 8.5 & 9.5 & 8.5 & - \\
\hline $\begin{array}{l}\text { At Lethbridge } \\
\text { (fish survival) }\end{array}$ & 11.5 & 11.5 & 11.5 & 15.0 & 20.0 & 20.0 & 20.0 & 20.0 & 15.0 & 15.0 & 11.5 & 11.5 \\
\hline
\end{tabular}

* fish habitat minimum flows are minimum flow at Fort Macleod

** $10 \mathrm{~m} 3 / \mathrm{s} \mathrm{June} 1-15$ and $8.5 \mathrm{~m} 3 / \mathrm{s} \mathrm{June} 16-30$

*** fish habitat minimum flows are equal to fish survival at Lethbridge

c) Flow requirements for recreational boating downstream of the oldman river dam, May through September

\begin{tabular}{|l|l|l|l|l|}
\hline Location & Boulder run & Brocket & Fort Macleod & Lethbridge \\
\hline Flow $\left(\mathrm{m}^{3} / \mathrm{s}\right)$ & 25 to 80 & over 25 & over 20 & over 25 \\
\hline
\end{tabular}

\section{References}

Alberta Environmental Protection. 1994. Oldman River Dam and Reservoir Operational Strategy (June 1994). Water Resources Service. 23 pp. + Appendices. 


\section{Appendices}

\section{Appendix A}

Oldman River Dam Environmental Monitoring Committee: Objectives, Terms of Reference and Scope of Monitoring Program

Objectives of the Monitoring Committee

$L$ Evaluate performance of mitigation projects (post-implementation).

$L$ Report on environmental effects of the project including downstream conditions.

$L$ Make comparisons of recorded environmental effects to impact predictions made prior to the project.

Terms of Reference

$\llcorner$ Establish an annual monitoring program (i.e.: sampling sites, sampling frequencies, parameters analyzed, analytical methods).

$\llcorner\quad$ Establish implementation methods.

$\llcorner$ Verify monitoring results.

$\llcorner$ Prepare/review data interpretation reports.

$\llcorner$ Advise the Environmental Advisory Committee as requested.

$L$ Advise the Operations Committee on the environmental impacts of operations and predicted impacts of proposed revision to operations.

$\llcorner$ Provide direction to the 0ldman River Dam Biologist.

\section{Scope of Monitoring Program}

$L$ water quality within and downstream of the reservoir

$\llcorner\quad$ limnological conditions within the reservoir

$L$ mercury in fish above, within and downstream of the reservoir

$L$ riparian vegetation downstream of the reservoir

$L$ success of fisheries mitigation program in compensating for lost fish habitat

$L$ success of wildlife mitigation program in compensating for lost wildlife habitat

$L$ response of fish population to habitat mitigation and downstream flow regime

$L$ response of wildlife population to habitat mitigation

$\llcorner$ effects upon historical resources

$\llcorner$ effects upon other related components

$\llcorner$ groundwater level monitoring 
Appendix B

\section{Members of the Oldman River Dam Environmental Monitoring Committee}

Annette Trimbee*/Russ Lewis (Chairperson) - Alberta Environmental Protection

Denis Magowan - Alberta Environmental Protection

James Barlishen*/John Englert - Alberta Public Works, Supply and Services

John Mahoney - Alberta Environmental Protection

Lorne Fitch/Michael Bryski - Alberta Environmental Protection

Brian Ronaghan*/Roderick Vickers - Alberta Community Development (Provincial Museum of Alberta)

Jim Moore*/Shaole Wu*/Angela Wharmby - Alberta Research Council

David Trew*/Pat Mitchell*/Karen Saffran - Alberta Environmental Protection

Glen Hopky*/Garry Linsey - Fisheries and Oceans Canada (Winnipeg)

Martin Paetz*Barrie Rennick* - Alberta Environmental Protection

J.B. Kemper*- Alberta Environmental Protection

* - former member 


\section{Appendix C}

\section{Evaluation Criteria for Establishing Monitoring Priorities}

Each year, members of the Environmental Monitoring Committee (EMC) propose projects to be included in the general monitoring program for the following year. To date, the number of projects proposed has been more than could be reasonably completed in a year. The EMC has therefore established eleven criteria to determine the relative importance of each proposal. The evaluation criteria were selected to ensure that the importance of completing each project is identified. The final rankings of proposed projects are made by consensus within the Committee. The following is a brief explanation of each of the criteria adopted by the EMC on March 3, 1993.

\section{Implications of missing an opportunity}

Certain components of the monitoring program may need to be completed at particular times to ensure the validity of the program. For example, monitoring changes in levels of mercury in fish needs to be done early in the project because increases are normally found in the first few years. Failure to sample mercury levels at this time would seriously reduce the confidence of the study. In contrast, sedimentation in the reservoir proceeds much more slowly and may not be measurable for some years. Missing an opportunity to sample sediment deposition several times in the initial years would not greatly affect the integrity of this particular study.

\section{Importance of data collection for decision- making}

Data are needed to assist in the formation of decisions related to both the operation of the Oldman River Dam and the management of the mitigation program. It is best to ensure the information is available in a timely fashion to the decision makers. An example of this would be the monitoring of water quality downstream of the dam to help managers decide whether adjustments in the operational plan are needed to ensure water quality objectives are met.

Can the work be done through another program? Other provincial agencies might be able to collect and analyse data as part of their regular program thereby eliminating duplication of effort and possibly reducing program costs. An example would be collection of fish population data by Fish and Wildlife following stocking in the Oldman River downstream of the Oldman River Dam.

\section{Continuity of a monitoring project}

Monitoring programs may require data collection over several years. Premature termination of a program may reduce the value of data already collected or render it useless. This criterion was established to ensure that programs continue at an appropriate pace and interval to generate meaningful results.

\section{Links between components}

The data collected for one project may be useful in other components. These links need to be identified so that the greatest benefit is gained from each study. Information gained from a study on regeneration of grasslands can also be employed in establishing grazing management plans, monitoring changes in habitat abundances, or estimating shifts in bird and wildlife populations around the reservoir.

\section{Irreversibility of impacts}

The presence and operation of the Oldman River Dam can have irreversible effects on the environment. Some irreversible effects may be preventable whereas others may not. The reduction of sediment load downstream from the reservoir would be an example of the latter. 


\section{Relation to core objectives}

Proposed projects should meet at least one of the core objectives of the Environmental Monitoring Committee (see Appendix A).

\section{Adequacy of data}

The proposed project must collect sufficient and appropriate data to allow scientific analysis. The Committee looks for assurances that data collected for long term projects are compatible for the duration of the study.

\section{Science and public interest}

The EMC recognizes that public interest varies for each aspect of the monitoring program. The Committee works to ensure that all components of the monitoring program receive appropriate levels of support.

\section{Regional and provincial significance of} doing work

The EMC attempts to identify studies with a wide range of applicability. For example, monitoring of Wildlife Control Areas provides information on minimum size requirements and public compliance that can be used to establish other Control Areas in Alberta.

Costs

The Committee reviews costs to ensure that funding allocated to each proposal is appropriate. 


\section{Appendix D}

\section{Terms and Conditions of Approval under the Navigable Waters Protection Act}

Canada Department of Transport

Navigable Waters Protection Act, Part I

Section 5(1)

8200-86-370 (AMAP)

Approval

Applicant:

Alberta Department of Environmental Protection

10th Floor, Petroleum Plaza, South Tower

9915 - 108 Street

Edmonton, Alberta

Work: $\quad$ Dam

Site-Location: $\quad$ Oldman River, N1/2 Section 17, Township 7, Range 29, W4M, near Pincher Creek, Province of Alberta

Important Notice: This document authorizes the work pursuant to Section 5(1) of the Navigable Water

Protection Act.

Whereas the above-named applicant has made application to the Minister of Transport under the Navigable Waters Protection Act for approval of the above-described work at the above-referred to site in accordance with the attached plan(s);

Whereas it is considered advisable to approve the said work at the said site and plan(s) thereof for a period of 50 years, subject to the following term(s) and condition(s):

1. The proponent shall undertake the evaluation, management and monitoring of hydrological changes related to navigation and shall provide the Department of Transport with periodic reports.

2. The proponent shall, subject to the concurrence and/or participation of the Peigan First Nation, carry out the evaluation, management and monitoring of the cottonwood forests on the Peigan Reserve.

3. The proponent shall, subject to the concurrence and/or participation of the Peigan First Nation, carry out the evaluation, management and monitoring of wildlife and wildlife habitat including migratory birds that are on the Peigan Reserve.

4. The proponent shall in cooperation with the Minister of Fisheries and Oceans, develop a plan of monitoring, evaluating and managing all waterways affected by the Oldman River dam that will protect fish and fish habitat.

5. The proponent shall in cooperation with the Minister of Transport maintain a reserve of water in the reservoir for navigation. This reserve will be sufficient to ensure minimum flows downstream from the Lethbridge Northern Irrigation District weir to provide flexibility in flow regimes to manage for navigation and conservation.

6. The proponent shall provide a reserve of water for navigation and conservation purposes.

7. The proponent shall provide boat-launching facilities to allow for portaging around the dam. The position of structures for boat launching shall be discussed with the NWP Regional Officer with respect to navigation safety. 
8. The proponent shall install a permanent control boom across the reservoir at a safe distance upstream of the spillway for the safety of vessels. The boom shall be painted yellow, carry yellow retroreflective material and be marked with yellow flashing lights. The characteristics of the lights shall be: 15 flashes per minute, $0.5 \mathrm{sec}$ light, 3.5 sec dark.

9. The proponent shall demonstrate to the satisfaction of the Minister of Transport that the operating regime of the Oldman River Dam will not result in unsafe navigation conditions above or below the dam or near the Lethbridge Northern Irrigation District weir.

10. Fisheries mitigation works such as groynes shall not be constructed so as to become a danger to navigation.

11. The proponent shall at all times permit the Minister of Transport or his representatives to monitor the rate of discharge of water.

12. Public recreational facilities such as boat launching ramps, floats and bank protection shall be constructed in such a manner as to enhance public safety.

13. The proponent shall ensure that debris control and removal procedures are in place and that debris is removed from the waterway.

14. The proponent shall provide unimpeded access to the Minister of Transport or his/her representative for inspection purposes, specifically to monitor the establishment of mitigation measures and adherence to the conditions of the NWPA Approval document.

15. The proponent shall provide the Department of Transport with periodic environmental management progress reports.

Therefore, the Minister of Transport, pursuant to the provisions of the Navigable Water Protection Act, Revised Statues of Canada, 1985, chapter no. 22, hereby approves the said work at the said site and plan(s) thereof for the period of time aforesaid providing:

a) the construction of the work is commenced within six (6) months and completed with three (3) years of the date hereof;

b) the work is built, placed and maintained in accordance with the plan(s), the Navigable Waters Works Regulations and the aforesaid term(s) and condition(s).

Ottawa, Sept. 21993 


\section{Appendix $\mathrm{E}$}

\section{Conditions of Authorization - Canada Department of Fisheries and Oceans}

Authorization issued to:

Name:

Address:

Name of Water Body:

Description of Location:

Valid Authorization Period:

Description of Works:
Her Majesty the Queen in right of Alberta as represented by the Minister of Environmental Protection and the Minister of Public Works, Supply and Services ("Alberta")

Alberta Environmental Protection

10th Floor Petroleum Plaza

9915 - 108 Street.

Edmonton, AB T5K 2C9

Attention: Jacob W. Thiessen

Assistant Deputy Minister, Water Resources Services

Oldman River, Alberta

The dam is situated on the Oldman River a short distance downstream of the confluence of the Oldman, Crowsnest and Castle rivers, approximately 10 kilometres northeast of the town of Pincher Creek in southwest Alberta. More specifically, the site is positioned in Section 17, Township 7, Range 29, West of the fourth Meridian at approximately $113^{\circ} 34^{\prime}$ longitude and $49^{\circ} 34^{\prime}$ latitude.

From: $16 / 08 / 1994$ to $31 / 03 / 2000$

Based on information provided by Alberta to the Department of Fisheries and Oceans, the works and undertakings include the operation and maintenance of the Oldman River Dam, a flow regulation dam, and all its appurtenant structures, the reservoir and all related works and all fisheries mitigation works relating thereto ("the works").

\section{Definitions:}

1. The following definitions apply:

\section{"Environmental Advisory Committee" (EAC)}

EAC means that committee appointed by the Alberta Minister of Environmental Protection which is comprised of public representatives including but not limited to the Local Advisory Committee, the Peigan Band, downstream water users, and the environmental community. The EAC will also have a member appointed by the federal government in accordance with the Federal Government Response to the Oldman River Dam Project Environmental Review Panel Report. The EAC will report to and advise the Alberta Minister of Environmental 
Protection on matters pertaining to the operation and environmental impact of the Oldman River dam. The duties of the EAC will include making recommendations related to:

i. operations of the project;

ii. fisheries habitat mitigation; and

iii. monitoring.

\section{"Fish Habitat Program"}

Fish Habitat Program means a program to replace or compensate for habitat harmfully altered, disrupted or destroyed by the works and undertakings, and includes habitat mitigation upstream and downstream from the reservoir.

\section{"Monitoring Committee"}

Monitoring Committee means the committee established by Alberta which is composed of technical specialists from Alberta Environmental Protection, other relevant Alberta departments and others as appointed from time to time and a member appointed by the Department of Fisheries and Oceans. The committee will, within the terms and conditions of this authorization:

i. review and establish specific program details such as sampling sites, sampling frequencies, parameters analyzed and analytical methods;

ii. identify means by which the monitoring program will be implemented;

iii. verify monitoring data;

iv. prepare and review data;

v. evaluate the effectiveness of completed fisheries habitat mitigation works;

vi. provide input to the Operations Committee on the environmental impacts of operations and the potential impacts of proposed revisions to operations; and

vii. advise the EAC as requested.

\section{"Operations Committee"}

Operations Committee means the committee, established by Alberta whose responsibilities include:

i. recommending to Alberta, revisions to the Operational Strategy from time to time;

ii. reviewing the environmental impacts of operations and assessing potential impacts of proposed revisions to operations; and

iii. providing technical expertise to the EAC in evaluating the potential impacts of EAC recommendations on water users, river flows, reservoir levels, fish habitat, and water quality.

\section{“Operational Strategy"}

Operational Strategy means the strategy entitled SS0394F - Year 2000, as submitted by the EAC on June 2, 1994 to the Alberta Minister of Environmental Protection for implementation by the Alberta Controller of Water Resources. 
"P1"

P1 means highest quality pool type. Maximum depth generally exceeding 1.5 metres; average depth 1.0 metre or greater; high instream cover at all flow conditions (boulders, bedrock fractures, depth, bank irregularities).

\section{"Pool"}

Pool means portion of river with reduced velocity and increased depth with respect to surrounding areas; water surface is unbroken.

\section{"R1"}

R1 means highest quality run type. Maximum depth generally exceeding 1.5 metres; average depth 1.0 metres; high instream cover at all flow conditions (boulders, bedrock fractures, depth, bank irregularities).

\section{"R2/BG"}

R2/BG means moderate quality run type; presence of boulders in channel; maximum depth generally exceeding 1.0 metre; average depth 0.75 metre or greater.

\section{"Run"}

Run means a portion of river with depth and velocity characteristics intermediate to a riffle and pool; water surface is largely unbroken by bottom substrate.

\section{"Technical Working Group"}

Technical Working Group means the committee of representatives from Alberta Environmental Protection and Alberta Public Works Supply and Services and others appointed by Alberta from time to time, and the representative from Department of Fisheries and Oceans. The Technical Working Group is chaired by the Fisheries Mitigation Manager appointed by Alberta Public Works Supply and Services. The responsibilities of the Technical Working Group include:

i. developing specific fisheries habitat mitigation and evaluation plans for implementation;

ii. reviewing the results of mitigation evaluation in order to assess the effectiveness of completed works; and

iii. incorporating evaluation results into future fisheries habitat mitigation plans.

\section{Conditions of Authorization}

This Authorization is issued by the Minister of Fisheries and Oceans (the Minister) and is subject to the following conditions:

\section{Operational}

2. Alberta shall operate the works in accordance with the operational parameters defined in the Operational Strategy, taking into account the protection of fish habitat.

3. Alberta shall establish the following committees:
a. an Environmental Advisory Committee ("EAC");
b. an Operations Committee;
c. a Technical Working Group; and
d. a Monitoring Committee. 
4. Alberta will, in making real time adjustments to the Operational Strategy, take into account the protection of fish habitat.

\section{Mitigation}

5. Alberta shall design and implement a Fish Habitat Program, in consultation with the Technical Working Group. This Program will focus on, but not necessarily be limited to:

a) creation of approximately 225,000 square metres of R1, P1 and R2/BG fish habitat in the mainstems and tributaries of the Oldman, Crowsnest and Castle Rivers ("the habitat replacement objective"). The techniques to achieve this may include flow deflectors, rock weirs, excavated runs and pools, boulder gardens, fish stocking, instream and riparian tree covers, bank stabilization or other techniques.

b) Working toward establishment of a self-sustaining trout population downstream of the reservoir with the aid of regulated flows, habitat mitigation, stocking or other techniques.

6. Alberta shall ensure the continued maintenance of Fish Habitat Program works, including the fisheries mitigation works initiated before the issuance of this authorization.

\section{Monitoring}

7. Alberta will design and implement a monitoring program on water quality and quantity in the reservoir and below the dam to assist in determining if fish and fish habitat are being protected. The design of the monitoring program shall include but not be limited to: flows, temperature, dissolved oxygen, ammonia, dissolved phosphorus, total dissolved nitrogen, nitrate, $\mathrm{pH}$, salinity, and turbidity, as appropriate. The monitoring program may be revised from time to time in consultation with the Department of Fisheries and Oceans' representative on the Monitoring Committee based on reviews of the monitoring results or as necessary to achieve the objectives of the Fish Habitat Program.

8. Two monitoring sites downstream of the Oldman River Dam for the measurement of water quality and quantity will be established, one of which will be located at the Long Term River Network Site at Lethbridge.

9. Alberta will monitor mercury levels in fish in the reservoir and downstream from the dam until such time as, in the opinion of the Minister of Fisheries and Oceans, mercury levels did not change from pre-development levels or that increased levels have returned to baseline conditions, or until such later time as Alberta and the Minister of Fisheries and Oceans may agree.

10. Alberta shall monitor the effectiveness of completed Fish Habitat Program works until such time as the objectives for the Program have been achieved.

11. All monitoring results will be provided to the Department of Fisheries and Oceans, as they become available, through the Department's representative on the Monitoring Committee and the Technical Working Group as appropriate. 

